\title{
The Role of microRNAs in Epithelial Ovarian Cancer Metastasis
}

\author{
Vu Hong Loan Nguyen ${ }^{1}$, Chenyang Yue ${ }^{1} \mathbb{D}$, Kevin Y. Du ${ }^{1}$, Mohamed Salem ${ }^{1,+}{ }^{\dagger}$ Jacob O'Brien ${ }^{1}$ \\ and Chun Peng ${ }^{1,2, *}$ \\ 1 Department of Biology, York University, Toronto, ON M3J 1P3, Canada; hlnguyen@my.yorku.ca (V.H.L.N.); \\ chenyangyue1993@gmail.com (C.Y.); kevin.yc.du@gmail.com (K.Y.D.); Mohamed.salem@cshs.org (M.S.); \\ jaobr@my.yorku.ca (J.O.) \\ 2 Centre for Research in Biomolecular Interactions, York University, Toronto, ON M3J 1P3, Canada \\ * Correspondence: cpeng@yorku.ca \\ + Current Address: Radiation Oncology, Cedars-Sinai Medical Center, Los Angeles, CA 90048, USA.
}

Received: 10 September 2020; Accepted: 23 September 2020; Published: 25 September 2020

\begin{abstract}
Epithelial ovarian cancer (EOC) is the deadliest gynecological cancer, and the major cause of death is mainly attributed to metastasis. MicroRNAs (miRNAs) are a group of small non-coding RNAs that exert important regulatory functions in many biological processes through their effects on regulating gene expression. In most cases, miRNAs interact with the 3' UTRs of target mRNAs to induce their degradation and suppress their translation. Aberrant expression of miRNAs has been detected in EOC tumors and/or the biological fluids of EOC patients. Such dysregulation occurs as the result of alterations in DNA copy numbers, epigenetic regulation, and miRNA biogenesis. Many studies have demonstrated that miRNAs can promote or suppress events related to EOC metastasis, such as cell migration, invasion, epithelial-to-mesenchymal transition, and interaction with the tumor microenvironment. In this review, we provide a brief overview of miRNA biogenesis and highlight some key events and regulations related to EOC metastasis. We summarize current knowledge on how miRNAs are dysregulated, focusing on those that have been reported to regulate metastasis. Furthermore, we discuss the role of miRNAs in promoting and inhibiting EOC metastasis. Finally, we point out some limitations of current findings and suggest future research directions in the field.
\end{abstract}

Keywords: epithelial ovarian cancer; metastasis; microRNAs (miRNAs)

\section{Introduction}

Ovarian cancer is the fifth leading cause of cancer-related deaths in females [1]. Based on the cell origin where ovarian tumors arise, ovarian cancer is classified into three categories: epithelial, germ cell, and stromal ovarian cancer. Several types of extremely rare ovarian cancer, such as small cell carcinoma and sarcomas, have also been reported [2]. Among them, epithelial ovarian cancer (EOC) accounts for more than $85 \%$ of ovarian cancer cases and is responsible for most ovarian cancer-related deaths [3]. EOC is further grouped into five different histological subtypes, including high-grade serous carcinomas (HGSC), low-grade serous carcinomas (LGSC), endometrioid carcinomas (EC), clear cell carcinomas (CCC), and mucinous carcinomas (MC) [3]. Though the morbidity of ovarian cancer is lower than that in endometrial and cervical cancers, it has the highest mortality rate among gynecological cancers [1]. The five-year survival rate of EOC is less than $45 \%$ [4], and relapse and poor prognosis occur in $80 \%$ of patients with advanced stages [5,6]. EOC is difficult to detect at the early stages as there are no effective screening methods and the presenting symptoms are vague. Therefore, patients are often diagnosed at the advanced stages when the tumor metastasis is already taking place [5]. 
MicroRNAs (miRNAs) are small non-coding RNAs that regulate gene expression within cells $[7,8]$. Studies have shown that $30-60 \%$ of human protein-coding genes are regulated by miRNAs [9]. Through regulation of the target gene expression, miRNAs are reported to control many biological processes, including proliferation, differentiation, cell cycle progression, apoptosis, and immune response [10]. Aberrant expression of miRNAs is implicated in many diseases, including cancer. Studies have demonstrated that miRNAs are involved in the progression of EOC [11,12]. Their levels are up- or down-regulated in EOC tumors and/or patient plasma samples, and their abnormal expression is highly associated with EOC metastasis [11,13]. In this review, we provide a brief overview of the biogenesis and mechanisms of actions of miRNAs and metastasis in EOC. We then discuss the dysregulation of miRNAs in EOC and the roles of miRNAs in promoting or suppressing cellular processes related to metastasis. Finally, we point out some limitations of current studies and suggest future research directions.

\section{Overview of miRNAs}

Depending on the genomic location, miRNAs can generally be classified as intragenic or intergenic. Intragenic miRNAs, which account for approximately $50 \%$ of the annotated miRNAs in humans, are generated from a host gene, mainly within the introns of protein-coding genes [14]. Expression of intragenic miRNAs is usually coupled with their host genes, while the transcription of intergenic miRNAs is directed by their own promoters $[15,16]$. However, it has also been reported that some intragenic miRNAs are transcribed independently of their host genes, generating pri-miRNA that also undergoes splicing [17].

The transcription of the primary miRNA (pri-miRNA) by RNA polymerase II is the first step of canonical miRNA biogenesis. Depending on the source of the miRNA, the pri-miRNA may be the mRNA of the host gene or an independent transcription unit, both containing a $5^{\prime} \mathrm{m} 7 \mathrm{G}$ cap and a $3^{\prime}$ poly-A tail $[18,19]$. Subsequently, pri-miRNAs undergo extensive processing within the nucleus. In the canonical pathway, the pri-miRNAs are converted into $\sim 70$ nt hairpin miRNA precursors (pre-miRNAs) via the microprocessor complex, which consists of an RNase III endonuclease, DROSHA, and the double-stranded-RNA-binding protein, DGCR8 (DiGeorge syndrome Critical Region 8) [20-22]. DGCR8 acts as the regulatory subunit that recognizes specific motifs within pri-miRNAs while DROSHA functions as the catalytic subunit. The pre-miRNA is then exported to the cytoplasm via a member of the nuclear transport receptor family, Exportin 5 (XPO5), together with Ran-GTP [20,23,24]. In the non-canonical pathway, precursor miRNAs are processed independently of the DROSHA/DGCR8 complex in the nucleus and exported outside the nucleus via Exportin $1[25,26]$.

In the cytoplasm, the pre-miRNAs are further processed into mature miRNAs by another RNase III endonuclease, Dicer [20,27]. Dicer cleaves pre-miRNA near the terminal loop, resulting in a short, on average $22 \mathrm{nt}$, RNA duplex [27-29]. Two mature miRNAs, originating from the $5^{\prime}$ and $3^{\prime}$ ends of the miRNA duplex and denoted with the postfix $-5 p$ and $-3 p$, respectively, can be generated through an unwinding process, guided by Argonaute (AGO) [30,31]. The miRNA duplex is unwound in an ATP-dependent manner and directly interacts with AGO via the $5^{\prime}$ and $3^{\prime}$ nucleotides of the miRNA, creating a stable association [32-34]. The strand that is incorporated into the miRNA-induced silencing complex (miRISC) is referred to as the "guide strand" and the other strand, known as the "passenger strand", is degraded $[35,36]$. Four AGO proteins (AGO1-4) have been characterized in humans and they are all capable of interacting with miRNAs [37].

In most reported cases, miRNAs repress their target genes at the post-transcriptional level [38]. They bind to partial complementary sequences in the $3^{\prime}$ untranslated region (UTR) of their target mRNAs, called the miRNA response element (MRE), inducing mRNA degradation and inhibiting translation initiation [39]. The AGO-bound miRNA and MRE interactions act as a guide to enable additional miRISC components to regulate target mRNA stability and protein output. GW182, which interacts directly with AGO, is crucial in localizing the poly-A tail of target mRNA to miRISC, as well as in the recruitment of deadenylase and decapping complexes [40]. PAN2/3 and CCR4/NOT deadenylase 
complexes are recruited via interaction with tryptophan motifs of GW182 [41,42]. Subsequently, mRNA poly(A) deadenylation is initiated by PAN2/3 and completed by CCR4/NOT complexes [41,42], followed by $\mathrm{m} 7 \mathrm{G}$ decapping, facilitated by decapping protein 2 (DCP2) and associated proteins [43]. The unstable deadenylated and decapped mRNA can then be degraded by $5^{\prime}-3^{\prime}$ exoribonuclease 1 (XRN1) [44]. In addition, miRNAs repress the translation initiation process through the release of eukaryotic initiation factors, eIF4A1 and eIF4A2, from the target mRNAs; as such, in some cases, miRNA can affect protein levels while leaving mRNA stability unaffected [45] (Figure 1).

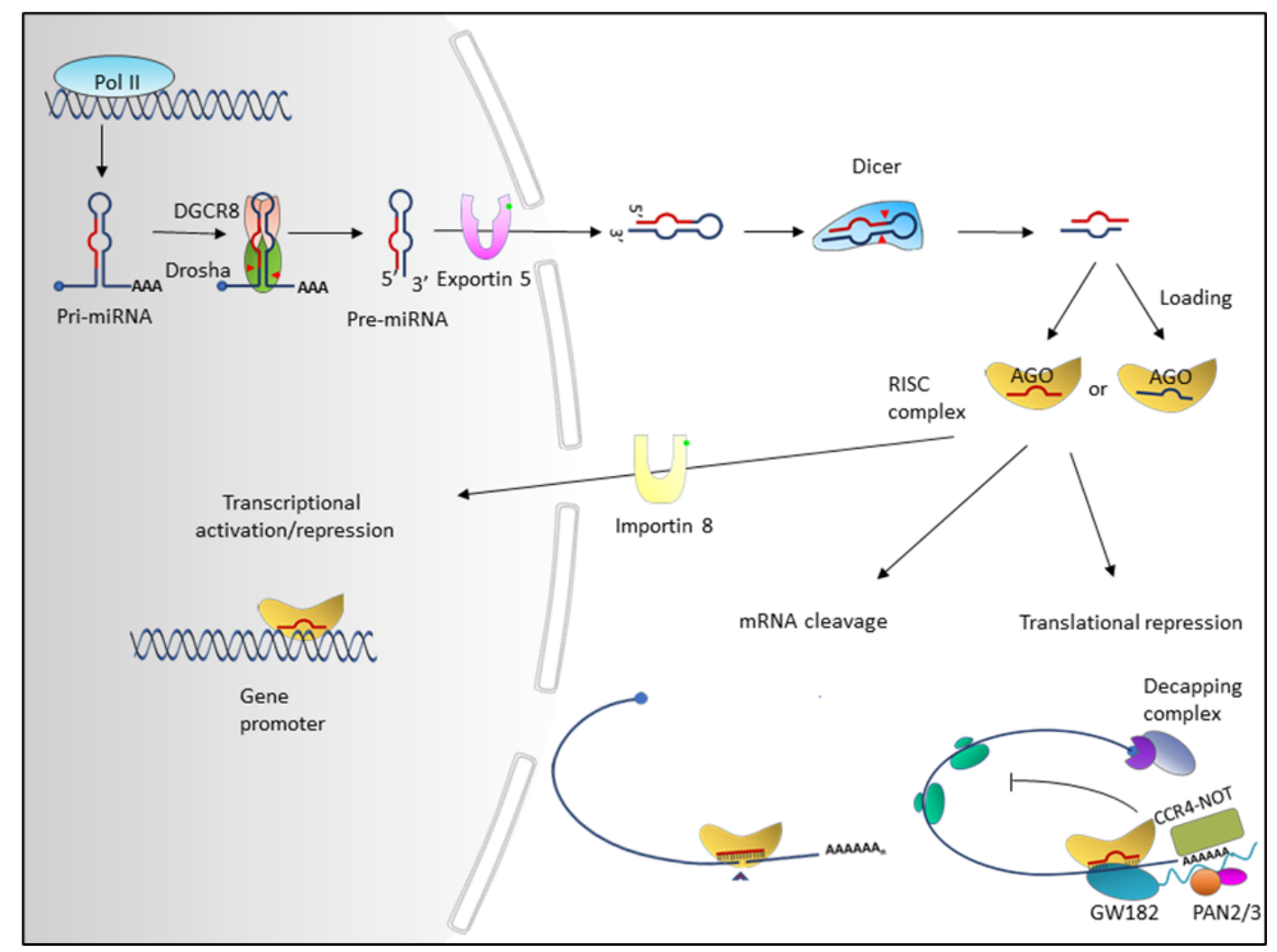

Figure 1. Biogenesis and functions of miRNA. MicroRNAs (miRNAs) are usually transcribed by polymerase II in the nucleus to generate primary microRNAs (pri-miRNA) transcripts. In the canonical pathway, the maturation of miRNAs is then performed by the microprocessor complex comprising of DROSHA, RNase III, and DCGR8. The microprocessor complex cleaves both strands of pri-miRNAs near the base of the primary stem loop, generating pre-miRNAs. Following cleavage, pre-miRNAs are actively transported from the nucleus to the cytoplasm by the Exportin 5/Ran-GTP complex. In the cytoplasm, RNase III endonuclease Dicer recognizes and cleaves pre-miRNA near the terminal loop, releasing a small RNA duplex. Subsequently, either strand (-5p or -3p) of the miRNA duplex is loaded into an AGO protein to form a miRNA-induced silencing complex (miRISC). Functionally, miRNAs direct the miRISC complex to target genes and modulate its expression by promoting either mRNA degradation and/or translation inhibition in the cytoplasm. The AGO protein of miRISC complex binds GW182 family proteins, which serve as scaffolds for multiple proteins including PAN2/3, and CCR4-NOT complexes. While the miRISC complex hinders the binding of eIF4F complex, PAN2/3 and CCR4-NOT mediate the poly(A) deadenylation of target mRNAs. The target mRNA is further decapped by a decapping complex and subjected to degradation via the exoribonuclease XRN1. In addition, the miRISC complex can be transported into the nucleus via Importin 8/RAN-GTP complex and binds to target gene promoters to regulate its transcription.

More recently, it has been shown that miRNAs have binding sites on other regions of the mRNAs, including coding regions and $5^{\prime}$ UTR, or on DNA promoter regions [46]. Interestingly, it was found that the binding of miRNA to the coding regions or $5^{\prime}$ UTR of mRNA exerts a silencing effect on gene 
expression while the interaction of miRNA with the promoter region could induce transcription [47-49]. Conversely, there is some evidence supporting miRNAs' role in promoting translation under specific conditions $[50,51]$.

\section{Ovarian Cancer Metastasis}

Metastasis is a complex multistep process in which cancer cells disseminate from primary tumors and start new tumors at different sites in the body. This process is regulated by a specific set of genes and signaling pathways. EOC cells mainly metastasize through the transcoelomic pathway [52], in which cells disseminate from the primary EOC tumor by undergoing epithelial-to-mesenchymal transition (EMT) [52] and float freely as spheroids in the ascitic fluid within the peritoneal cavity. The metastatic cells then attach onto the mesothelium lining or invade deeper into the peritoneal organs [53]. In addition, metastatic ovarian cancer cells can transit in the blood or lymph vessels and undergo extravasation to establish new tumors in hematogenous and lymphatic metastasis $[53,54]$. EOC metastasis to secondary sites accounts for approximately $90 \%$ of all ovarian cancer deaths [53]. Therefore, understanding the underlying mechanisms of EOC metastasis could lead to the development of more effective therapeutic tools.

EMT is a biological process which is activated during normal embryonic and organ development, as well as tissue repair [55]. The role of EMT in tumor metastasis has been established in many types of cancers, including EOC [56-58]. In EMT, epithelial cells undergo phenotypic alterations through the loss of cell polarity, cell-cell attachment, and gain mesenchymal phenotypes, such as fibroblastoid morphology with increased migratory and invasive properties. EMT is a critical step in ovarian cancer metastasis [59]. Downregulation of epithelial cadherin (E-cadherin, CDH1) and upregulation of mesenchymal neural cadherin (N-cadherin, $\mathrm{CDH} 2$ ) are key elements of EMT. E-cadherin is a transmembrane glycoprotein that associates with $\beta$-catenin at the adherens junctions [59]. Loss of E-cadherin results in the destabilization of adherens junctions, promoting cell migration, invasion, and metastasis. E-cadherin expression is repressed directly by many transcription factors, including Snail (SNAI1), Slug (SNAI2), and zinc finger E-box binding homeobox (ZEB)1 and ZEB2, and indirectly by TWIST and TCF4 $[60,61]$. In addition, Vimentin (VIM), a component of intermediate filaments, is abundantly expressed in mesenchymal cells [62] and exerts inhibitory effects on E-cadherin expression, and cell-cell adhesion, while promoting cell migration and invasion [63]. Therefore, Vimentin is not only an EMT marker but also directly promotes EMT in EOC.

In EOC, EMT is induced by several signaling pathways, including transforming growth factor- $\beta$ (TGF- $\beta$ )/Smads, Wnt/ $\beta$-catenin, PI3K/AKT, Hedgehog, Sonic, and Notch [64]. Wnt signaling promotes the localization of $\beta$-catenin into the nucleus, which, in turn, interacts with T-cell factors (TCF/LEF) to regulate transcription [65]. The pathway inhibits E-cadherin by promoting the expression of E-cadherin repressors, such as Snail, Slug, and TWIST [65,66]. TGF- $\beta$ also enhances EMT through its downstream mediators, SMAD2, SMAD3, and SMAD4 [67]. In addition, the MAPK and PI3K/AKT pathways, activated by many growth factors, or through cross-talks with other signaling molecules, also play critical roles in promoting EMT. For example, epidermal growth factor (EGF) signals through the ERK1/2 and PI3K/AKT pathways to induce EMT [68]. Hepatocyte growth factor (HGF) acts through its receptor, c-Met, and enhances EMT by activating multiple signaling pathways, including MAPK, Wnt/ß-catenin, and PI3K/AKT [69-71]. Hedgehog glioma-associated oncogene1 (Shh-Gli1) positively regulates EMT via crosstalk with PI3K-AKT [72]. In addition to functions in mitotic progression, Aurora kinase A (AURKA) has been reported to regulate EOC cell migration and invasion in vitro and in vivo [73]. Treatments with AUKA inhibitors, such as alisertib, inhibited migration, adhesion, and EMT via the PI3K/AKT/mTOR- and Sirtuin-1-mediated pathways [73,74], suggesting a potential therapeutic advancement in controlling EOC dissemination. Finally, focal adhesion kinase (FAK) is an important component of various pro-metastatic signaling pathways which promote cancer metastasis, including cell motility [75], cell survival [76,77], invasion [78,79], and EMT [80]. Increased FAK levels 
are found in several cancers, including EOC $[79,80]$. In addition, FAK activation, which is determined by p-FAK, increases with tumor progression [80].

Actin filament dynamics are regulated strictly to maintain cell shape and control cell motility [53]. The increase in EOC cell mobility is mediated by actin filament remodeling via the activation of GTPase signaling pathways. For example, GTPase RAP1B has been reported to activate Src and JNK to facilitate integrin-mediated actin remodeling and thereby promote metastasis [81]. DAAM1, which is upregulated in EOC tumors, activates RHOA, induces the formation of microfilaments, and promotes cell migration and invasion [82]. In addition, Lim kinase 1 (LIMK1), a member of serine-threonine protein kinases that acts downstream of RHO GTPase signaling, also participates in actin remodeling in EOC [83]. LIMK1 is a key player in the reorganization of the actin cytoskeleton by inactivating actin-binding factor cofilin through phosphorylation [84]. LIMK1 protein levels are upregulated in EOC and correlated with poor differentiation [83]. In addition, knockout of LIMK1 inhibited migration and invasion of EOC cells [83], supporting its role in promoting EOC cell mobility.

Most EOC metastasis occurs in the peritoneal cavity. Once escaping the primary site, ovarian tumor cells transit in the ascitic fluid as single cells or aggregated cells, referred to as spheroids, and exhibit cancer stem-like properties $[85,86]$. Cancer cells then adhere to the mesothelium lining of the peritoneum through the binding of integrin receptors to the extracellular matrix (ECM) elements of the mesothelial cells [53]. The integrin-ECM interaction was suggested to activate integrin-linked kinase (ILK) through phosphorylation, promoting a phosphorylation cascade of a variety of ILK-intracellular substrates, including protein kinase B (PKB/AKT), glycogen synthase kinase-3 (GSK-3), and myosin light chain at focal adhesions, and promoting cell adhesion and invasion to the mesothelium [87]. In addition, ovarian tumor cells increase the production of proteolytic enzymes, such as matrix metalloproteases (MMPs), which recognize and degrade ECM elements, enhancing invasive behavior. MMPs play a role in EMT and they are also activated by genes and signaling pathways that induce EMT [88]. In EOC, it has been reported that knockdown of SNAI1 reduced MMP2 but upregulated its inhibitor, TIMP2, suggesting that Snail induces MMP activity [89]. Moreover, EOC cells avoid apoptosis while detaching from primary sites and circulating in ascites or transiting to a distant location by resisting anoikis, a programmed cell death which is activated to inhibit anchorage-independent growth or cell adhesion to an inappropriate matrix [90]. Among steps that occur in cancer metastasis, escaping apoptosis is critical in tumor development and metastasis [91].

Interaction between cancer cells and the tumor environment also plays a role in metastasis. Hypoxia is commonly observed in fast-growing tumors with an insufficient supply of oxygen. Under hypoxic conditions, the association of stabilized hypoxia-inducible factor (HIF)- $1 \alpha$ and HIF-2 $\alpha$ [92] with HIF-1 $\beta$ induces the expression of downstream target genes that are involved in cell invasion, and metastasis [93]. LOX, one of the target genes induced by HIF-1 complex, has been shown to cross-link collagen and provide a linear track for cell migration [94,95]. In addition, HIF-1 complex modulates the downregulation of DMN2, resulting in decreased endocytosis, an energy-consuming cellular process [94]. Hypoxia has also been reported to down-regulate BRCA1 expression via Retinoblastoma-associated protein E2F transcription factor and suppresses homologous recombination in hypoxic cancer cells, potentially increasing genomic instability [96,97]. Furthermore, the behaviors of metastatic EOC cells are influenced by secreted factors residing in ascites. Cytokine CXCL12 and hyaluronic acid in ascitic fluid have been demonstrated to interact with CXCR4 and CD44 receptors on EOC cell surface respectively, stimulating cell migration, angiogenesis, and localization to the peritoneal surface [53,98-100].

Lastly, the metastasis of EOC cells is enhanced by an immunosuppressive microenvironment. Tumor-infiltrating lymphocytes (TILs), such as T cells, B cells, macrophages, and natural killer cells, were also found to be present in ascites and pelvic peritoneal biopsies of advanced ovarian cancer patients [101]. Among them, tumor-associated macrophages (TAMs) play a role in the suppression of adaptive immunity. TAMs induced the imbalance of Treg/Th17 and promoted angiogenesis and metastasis via cross-talk with endothelial cells in EOC [102,103]. In addition, TIL-produced 
cytokines, such as IL-6, IL-10, ARG-1, and CCL-2, have been reported to promote tumor progression and metastasis, and are involved in immune subversion [104,105]. In addition, EOC cells promote immune evasion via downregulating tumor-associated surface ligands. MHC class I chain-related molecules A and B (MICA and MICB) are widely expressed on epithelial tumor cells and targeted by cytotoxic lymphocytes such as CD8+ T cells and natural killer (NK) cells [106]. Downregulation and internalization of MICA/B have been reported in EOC [106,107], allowing EOC malignant cells to escape immune surveillance.

\section{Dysregulation of miRNA Expression in Ovarian Cancer}

The expression of miRNAs is highly specific to cell types and developmental stages $[108,109]$. However, aberrant expression of miRNAs is commonly observed in EOC and associates with its progression [59]. Many miRNAs have been identified to be differentially expressed in EOC. These changes in miRNA abundance are often associated with alterations in cell migration, invasion, and metastasis, as listed in Table 1. Abnormal levels of miRNAs have been detected in tumor tissues, plasma, urine, and/or ascitic fluids. Such dysregulation can be attributed to alterations in DNA copy number, epigenetic regulation, and miRNA biogenesis.

\subsection{Aberrant Expression of Metastasis-Associated miRNAs in EOC}

In EOC tumors compared to normal ovarian tissues, upregulation of miR-181a [110], miR-616 [111] and miR-590-3p [112], and downregulation of miR-125b [113], miR-148a-3p [114], and miR-375 [115] levels have been reported. However, inconsistent findings have also been reported. For example, miR-124-3p, miR-148a-3p, miR-203a, and miR-375 were detected exhibiting differential expression in EOC specimens with both downregulation and upregulation [114,116-119]. Several other miRNAs listed in Table 1 have also been shown to be either up- or down-regulated in different studies. The reasons for such discrepancies are unclear; however, it may be related to sample size and/or heterogeneity within tumor samples or between different EOC subtypes. In addition, some of these studies did not specify the subtypes of tumors or only used a few tumor samples. Different EOC subtypes have unique origins and specific molecular features and, therefore, it is possible to exhibit different miRNA expression patterns. To date, only a few studies have examined miRNAs in different subtypes of EOC. Using microarray analyses to compare serous, endometrioid, and clear cell tumors with normal ovarian tissues, Iorio et al. (2007) found that while some miRNAs were commonly up- or down-regulated among different subtypes of EOCs, some miRNAs were dysregulated only in a specific subtype [120]. It has also been indicated that miR-510 expression was higher in LGSC and CCC subtypes but lower in HGSC compared to normal ovarian tissues [121]. Choosing proper controls is a challenging task in EOC research. Many researchers used normal ovarian or adjacent non-cancerous tissues as controls. However, it is now believed that the majority of EOCs are originated outside the ovary $[3,122]$. For example, HGSCs are thought to be derived from fallopian tube (FT) and ovarian surface epithelium while ECs and CCCs are originated from endometriosis [3]. The origin of MCs and LSGCs is still unclear, but they are frequently found to be associated with borderline tumors [3]. Therefore, comparison between tumor tissues and normal ovarian tissues may not provide accurate information about miRNA dysregulation. A recent study compared miRNA expression profiles between endometriosis and EOC tissues and suggested the potential role of miR-93, miR-325, and miR-492 in the malignant transformation of endometriosis to EOC [123]. Further investigation of miRNA expression in different subtypes in comparison with their tissues of origin would provide insights into their diagnostic and/or prognostic significance. 
In addition to tumor tissues, the aberrant expression of miRNAs has also been detected in extracellular vesicles, especially exosomes, of EOC patients [124]. Interestingly, malignant cells have been reported to secrete more exosomes when compared with normal cells [124]. Consistent with the dysregulation of miRNA levels found in EOC tissues, miR-590-3p [112] and miR-376a [125] were found to be upregulated in plasma and serum samples of EOC patients, respectively. Expressions of miR-200a [126] and miR-20a [106] were increased while miR-122 [127] and miR-199a [128] expressions were decreased in the serum of EOC patients. Furthermore, upregulation of miR-149-3p and miR-222-5p was detected in peritoneal exosomes which were isolated from ascites of EOC patients [129].

The dysregulation of miRNAs is correlated with EOC pathological features, such as tumor stage, grade, and lymph node and uterus invasion. Levels of miR-520h were gradually increased from stage I to stage III/IV of EOC tumors [130]. Upregulation of miR-520h was associated with increased ascite volumes and poor survival of EOC patients. In contrast, decreased levels of miR-26b were negatively correlated with tumor stage, grade, and ascite volumes [131,132]. In addition, abnormal miRNA levels have been reported to be associated with EOC metastasis. Bioinformatic analysis demonstrated that there was a correlation between downregulation of miR-216 with lymphovascular invasion, upregulation of miR-133a-2, miR-145, and miR-126 with uterus invasion, and upregulation of miR-302c with pelvic peritoneum invasion [120]. Furthermore, analysis from primary and metastatic EOC specimens indicated that downregulation of miR-124-2, miR-125b-1, miR-137, miR-203a, and miR-375 was highly associated with lymph node and distant metastasis [116]. miR-146a [133] and miR-19a [134] were also increased in metastatic EOC tumors comparing to the primary tumors, while miR-7 levels were decreased in metastatic EOC tumors compared to the primary tumors [68]. The upregulation and downregulation of these miRNAs are associated with advanced stage, lymph node metastasis, and survival of EOC patients. Therefore, miRNAs may potentially be used as prognostic biomarkers. 
Table 1. Metastasis-related miRNAs in epithelial ovarian cancer (EOC).

\begin{tabular}{|c|c|c|c|c|}
\hline $\begin{array}{l}\text { miRNA/ } \\
\text { miRNA Family }\end{array}$ & Altered Expression in EOC and Clinical Significance & Target Gene & In Vitro/In Vivo Effects & Citations \\
\hline \multicolumn{5}{|c|}{ Pro-Metastatic miRNAs } \\
\hline \multicolumn{5}{|c|}{ miRNAs upregulated in tumor tissues } \\
\hline miR-19a & $\begin{array}{l}\text { Upregulated in metastatic HGSC tissues compared to normal } \\
\text { ovarian tissues }\end{array}$ & ND & ND & [134] \\
\hline miR-182 & Upregulated in HGSC tissues compared to fallopian tube tissues & MTSS1 & $\begin{array}{l}\text { Promotes cell invasion in vitro, and tumor growth and } \\
\text { metastasis in vivo }\end{array}$ & {$[135,136]$} \\
\hline $\operatorname{miR}-328-3 p$ & $\begin{array}{l}\text { Upregulated in cancer stem-like cells isolated from HGSC } \\
\text { tissues compared to bulk cancer cells }\end{array}$ & $D D B 2$ & $\begin{array}{l}\text { Increases ALDH+ population and promotes spheroid } \\
\text { formation and CSC properties in vitro and tumor } \\
\text { growth and metastasis in vivo }\end{array}$ & [137] \\
\hline miR-130a & $\begin{array}{l}\text { Upregulated in HGSC tissues compared to normal fallopian } \\
\text { tube tissues }\end{array}$ & TSC1 & $\begin{array}{l}\text { Promotes cell proliferation, invasion, and EMT and } \\
\text { tumor growth and metastasis in vivo }\end{array}$ & [138] \\
\hline $\operatorname{miR}-301 b-3 p$ & $\begin{array}{c}\text { Upregulated in HGSC tissues compared to paired adjacent } \\
\text { normal tissues; positively correlated with tumor stage, lymph } \\
\text { node metastasis, and poor survival }\end{array}$ & СРEB3 & Promotes cell migration and invasion in vitro & [139] \\
\hline $\mathrm{miR}-520 \mathrm{~h}$ & $\begin{array}{c}\text { Upregulated in EOC tissues compared to benign ovarian } \\
\text { tumors and highest in HGSC compared to MC, EC, and CCC } \\
\text { subtypes; correlated with tumor stage, increased ascites, lymph } \\
\text { node metastasis, and poor survival }\end{array}$ & SMAD7 & $\begin{array}{l}\text { Promotes cell proliferation, invasion, and EMT in vitro } \\
\text { and tumor growth and metastasis in vivo }\end{array}$ & [130] \\
\hline miR-21 & $\begin{array}{l}\text { Upregulated in serous EOC, EC, and MC tissues compared to } \\
\text { ovarian cysts and normal ovarian tissues; positively correlated } \\
\text { with tumor stage and lymph node metastasis }\end{array}$ & ND & $\begin{array}{l}\text { Promotes cell proliferation, migration, and invasion } \\
\text { in vitro }\end{array}$ & [140] \\
\hline miR-205 & $\begin{array}{c}\text { Upregulated in EC subtype compared to normal } \\
\text { endometrial tissues }\end{array}$ & ESRRG & $\begin{array}{l}\text { Promotes cell proliferation, migration, and invasion } \\
\text { in vitro }\end{array}$ & [141] \\
\hline miR-146a & $\begin{array}{l}\text { Upregulated in omental metastatic serous EOC tumors } \\
\text { compared to primary EOC tumors }\end{array}$ & ND & $\begin{array}{l}\text { Promotes spheroid formation and cisplatin resistance } \\
\text { in vitro }\end{array}$ & [133] \\
\hline miR-551b & $\begin{array}{l}\text { Upregulated in recurrent serous EOC tissues compared to } \\
\text { primary EOC tumors; associated with advanced stage }\end{array}$ & $\begin{array}{l}\text { FOXO3 } \\
\text { TRIM31 }\end{array}$ & $\begin{array}{l}\text { Promotes cell proliferation, invasion, and colony } \\
\text { formation in vitro and tumor burden in vivo }\end{array}$ & [142] \\
\hline
\end{tabular}


Table 1. Cont

\begin{tabular}{|c|c|c|c|c|}
\hline $\begin{array}{l}\text { miRNA/ } \\
\text { miRNA Family }\end{array}$ & Altered Expression in EOC and Clinical Significance & Target Gene & In Vitro/In Vivo Effects & Citations \\
\hline miR-551b-3p & $\begin{array}{l}\text { Upregulated in HGSC tissues compared to normal ovarian } \\
\text { tissues; associated with poor outcome }\end{array}$ & STAT3 promoter & $\begin{array}{l}\text { Promotes cell proliferation, spheroid formation, and } \\
\text { survival in vitro and tumor burden in vivo }\end{array}$ & [143] \\
\hline miR-18b & $\begin{array}{l}\text { Upregulated in EOC tissues compared to normal ovarian } \\
\text { tissues; positively correlated with tumor grade and lymph node } \\
\text { metastasis }\end{array}$ & PTEN & Promotes cell migration and invasion in vitro & [144] \\
\hline miR-19b & $\begin{array}{l}\text { Upregulated in EOC tissues compared to matched non-tumor } \\
\text { tissues; positively correlated with tumor stage and lymph node } \\
\text { metastasis }\end{array}$ & PTEN & Promotes cell migration and invasion in vitro & [145] \\
\hline miR-23a & $\begin{array}{c}\text { Upregulated in EOC tissues compared to adjacent } \\
\text { normal tissues }\end{array}$ & $D L G 2$ & $\begin{array}{l}\text { Promotes cell proliferation, migration, and invasion } \\
\text { in vitro and tumor growth in vivo }\end{array}$ & [146] \\
\hline miR-181a & $\begin{array}{l}\text { Upregulated in recurrent EOC tissues compared to primary } \\
\text { EOC tissues; associated with poor survival }\end{array}$ & SMAD7 & $\begin{array}{l}\text { Promotes cell migration, invasion, survival, and EMT } \\
\text { in vitro and tumor growth and metastasis in vivo }\end{array}$ & [110] \\
\hline miR-181b & Upregulated in EOC tissues compared to normal ovarian tissues & LATS2 & Promotes cell proliferation and invasion in vitro & [147] \\
\hline miR-182-5p & $\begin{array}{l}\text { Upregulated in EOC tissues compared to non-tumor } \\
\text { ovarian issues }\end{array}$ & FOXF2 & $\begin{array}{l}\text { Promotes cell proliferation, and invasion in vitro and } \\
\text { tumor growth in vivo }\end{array}$ & [148] \\
\hline miR-194 & $\begin{array}{l}\text { Upregulated in EOC tissues compared to normal ovarian } \\
\text { epithelium tissues }\end{array}$ & PTPN12 & $\begin{array}{l}\text { Promotes cell proliferation, migration and invasion } \\
\text { in vitro }\end{array}$ & [149] \\
\hline miR-196a & $\begin{array}{l}\text { Upregulated in EOC compared to paired normal ovarian } \\
\text { tissues; positively correlated with tumor stage, and lymph node } \\
\text { metastasis }\end{array}$ & ND & ND & [150] \\
\hline miR-205 & $\begin{array}{l}\text { Upregulated in EOC tissues compared to normal ovarian } \\
\text { tissues; correlated with tumor stage and poor survival }\end{array}$ & $\begin{array}{l}\text { TCF21 } \\
\text { PTEN } \\
\text { SMAD4 }\end{array}$ & $\begin{array}{l}\text { Promotes cell proliferation, migration, and invasion } \\
\text { in vitro and tumor growth and metastasis in vivo }\end{array}$ & [151-153] \\
\hline miR-216a & $\begin{array}{l}\text { Upregulated in EOC tissues compared to normal ovarian } \\
\text { tissues; correlated with tumor stage, lymph node metastasis, } \\
\text { and poor survival }\end{array}$ & PTEN & $\begin{array}{l}\text { Promotes cell migration and invasion and EMT } \\
\text { in vitro }\end{array}$ & [154] \\
\hline miR-552 & $\begin{array}{c}\text { Upregulated in EOC tissues compared to paired non-tumor } \\
\text { tissues; associated with metastasis, recurrence, and poor } \\
\text { survival }\end{array}$ & PTEN & $\begin{array}{l}\text { Promotes cell proliferation, migration, and invasion } \\
\text { in vitro }\end{array}$ & [155] \\
\hline
\end{tabular}


Table 1. Cont

\begin{tabular}{|c|c|c|c|c|}
\hline $\begin{array}{c}\text { miRNA/ } \\
\text { miRNA Family }\end{array}$ & Altered Expression in EOC and Clinical Significance & Target Gene & In Vitro/In Vivo Effects & Citations \\
\hline miR-616 & $\begin{array}{l}\text { Upregulated in EOC tissues compared to adjacent non-tumor } \\
\text { tissues; associated with metastasis, tumor stage and grade, and } \\
\text { poor survival }\end{array}$ & TIMP2 & $\begin{array}{l}\text { Promotes cell migration, invasion, and EMT in vitro } \\
\text { and metastasis in vivo }\end{array}$ & [111] \\
\hline miR-630 & $\begin{array}{l}\text { Upregulated in EOC tissues with high levels of hypoxia } \\
\text { compared to low levels of hypoxia; associated with } \\
\text { poor survival }\end{array}$ & DICER1 & $\begin{array}{l}\text { Promotes cell migration, invasion, and EMT in vitro } \\
\text { and tumor growth and metastasis in vivo }\end{array}$ & [156] \\
\hline miR-939 & $\begin{array}{l}\text { Upregulated in EOC tissues compared to matched adjacent } \\
\text { normal tissues }\end{array}$ & APC2 & $\begin{array}{l}\text { Promotes cell proliferation, colony formation, cell } \\
\text { migration, invasion, and EMT in vitro }\end{array}$ & {$[157,158]$} \\
\hline \multicolumn{5}{|c|}{ miRNAs upregulated in secreted exosomes and circulating body fluids } \\
\hline miR-376a & $\begin{array}{l}\text { Upregulated in EOC tissues compared to paired adjacent } \\
\text { normal tissues and in blood samples of EOC patients compared } \\
\text { to healthy controls; associated with advanced stages }\end{array}$ & $\begin{array}{l}\text { KLF15 } \\
\text { CASP8 }\end{array}$ & $\begin{array}{l}\text { Promotes cell proliferation, migration, and invasion } \\
\text { in vitro and tumor growth in vivo }\end{array}$ & [125] \\
\hline miR-590-3p & $\begin{array}{l}\text { Upregulated in EOC tissues compared to normal ovarian } \\
\text { tissues, and in plasma of EOC patients compared to those with } \\
\text { benign gynecologic disorders; correlated with tumor grade }\end{array}$ & $\begin{array}{l}\text { FOXA2 } \\
\text { FOXO3 } \\
\text { CCNG2 }\end{array}$ & $\begin{array}{l}\text { Promotes colony and spheroid formation, cell } \\
\text { migration, and invasion in vitro and tumor burden } \\
\text { in vivo }\end{array}$ & {$[112,159]$} \\
\hline $\operatorname{miR}-29-3 p$ & $\begin{array}{l}\text { Upregulated in exosomes secreted by M2 macrophages } \\
\text { compared to those derived from THP-1 cells; associated with } \\
\text { poor survival }\end{array}$ & STAT3 & $\begin{array}{l}\text { Promotes Tregs/Th17 imbalance in vitro and tumor } \\
\text { growth and metastasis in vivo }\end{array}$ & [102] \\
\hline miR-30a-5p & $\begin{array}{l}\text { Upregulated in urine samples of serous EOC patients compared } \\
\text { to healthy controls and higher in stage I/II compared to stage } \\
\text { III/V; associated with lymphatic metastasis }\end{array}$ & ND & Promotes cell proliferation and migration in vitro & [160] \\
\hline miR-149-3p & $\begin{array}{l}\text { Upregulated in peritoneal exosomes of EOC patients compared } \\
\text { to healthy controls; associated with poor survival }\end{array}$ & ND & ND & [129] \\
\hline miR-222-5p & $\begin{array}{l}\text { Upregulated in peritoneal exosomes of EOC patients compared } \\
\text { to healthy controls; associated with poor survival }\end{array}$ & ND & ND & [129] \\
\hline
\end{tabular}


Table 1. Cont

\begin{tabular}{|c|c|c|c|c|}
\hline $\begin{array}{l}\text { miRNA/ } \\
\text { miRNA Family }\end{array}$ & Altered Expression in EOC and Clinical Significance & Target Gene & In Vitro/In Vivo Effects & Citations \\
\hline \multicolumn{5}{|c|}{ Anti-Metastatic miRNAs } \\
\hline \multicolumn{5}{|c|}{ miRNAs down-regulated in tumor tissues } \\
\hline miR-145 & Downregulated in HGSC compared to normal FT tissues & $\begin{array}{l}\text { MTDH } \\
\text { TWIST } \\
\text { SOX9 } \\
\text { HMGA2 }\end{array}$ & $\begin{array}{l}\text { Inhibits cell proliferation, invasion, migration, EMT, } \\
\text { and spheroid formation in vitro and tumor growth } \\
\text { and metastasis in vivo }\end{array}$ & [161-163] \\
\hline miR-509-3p & Positively associated with survival in HGSC & YAP1 & $\begin{array}{l}\text { Inhibits cell invasion, migration, and spheroid } \\
\text { formation in vitro }\end{array}$ & [164] \\
\hline $\operatorname{miR}-1236-3 p$ & Downregulated in HGSC tissues compared to normal FT tissues & ZEB1 & Inhibits cell invasion, migration, and EMT in vitro & [165] \\
\hline miR-574-3p & $\begin{array}{l}\text { Decreased in EOC tissues compared to normal ovarian tissues, } \\
\text { significantly lower in serous EOC tissues compared to } \\
\text { non-serous EOC tissues; negatively associated with tumor stage }\end{array}$ & EGFR & Inhibits cell invasion and migration in vitro & [166] \\
\hline $\operatorname{miR}-25$ & $\begin{array}{l}\text { Downregulated in integrated mesenchymal EOC subtype } \\
\text { compared to epithelial EOC subtype based on TCGA database }\end{array}$ & SNAI2 & $\begin{array}{c}\text { Inhibits cell invasion, migration, and EMT in vitro and } \\
\text { tumor growth and metastasis in the orthotopic } \\
\text { xenograft mouse model }\end{array}$ & [167] \\
\hline miR-101 & $\begin{array}{l}\text { Decreased in integrated mesenchymal OC subtype compared to } \\
\text { integrated epithelial OC subtype from TCGA database }\end{array}$ & $\begin{array}{l}\text { ZEB1 } \\
\text { FN1 }\end{array}$ & $\begin{array}{l}\text { Inhibits cell invasion, migration, and EMT in vitro and } \\
\text { tumor growth and intraperitoneal metastasis in vivo }\end{array}$ & {$[168,169]$} \\
\hline $\operatorname{miR-7}$ & $\begin{array}{l}\text { Downregulated in metastatic EOC tissues from omentum or } \\
\text { peritoneum compared to primary EOC tissues; associated with } \\
\text { metastasis }\end{array}$ & EGFR & Inhibits cell invasion, migration, and EMT in vitro & [68] \\
\hline $\operatorname{miR}-17-5 p$ & ND & $\begin{array}{l}\text { ITGA5 } \\
\text { ITGB1 }\end{array}$ & $\begin{array}{l}\text { Suppresses cell adhesion and invasion in vitro and } \\
\text { peritoneal metastasis in vivo }\end{array}$ & [170] \\
\hline miR-106b & $\begin{array}{l}\text { Decreased in EOC tissues compared to normal ovarian tissues } \\
\text { and benign tumors; negatively associated with tumor stage and } \\
\text { grade }\end{array}$ & RHOC & $\begin{array}{l}\text { Inhibits cell proliferation, invasion, and migration } \\
\text { in vitro and tumor growth in vivo }\end{array}$ & [171] \\
\hline $\mathrm{miR}-23 \mathrm{~b}$ & $\begin{array}{l}\text { Decreased in EOC tissues compared to normal ovarian tissues } \\
\text { and benign tumors }\end{array}$ & CCNG1 & $\begin{array}{l}\text { Inhibits cell proliferation, invasion, and migration } \\
\text { in vitro and tumor growth in vivo }\end{array}$ & [172] \\
\hline
\end{tabular}


Table 1. Cont

\begin{tabular}{|c|c|c|c|c|}
\hline $\begin{array}{l}\text { miRNA/ } \\
\text { miRNA Family }\end{array}$ & Altered Expression in EOC and Clinical Significance & Target Gene & In Vitro/In Vivo Effects & Citations \\
\hline miR-26b & $\begin{array}{l}\text { Downregulated in EOC tissues compared to normal ovarian } \\
\text { surface epithelial tissues; inversely correlated with stage and } \\
\text { grade, and higher risk with distant metastasis, recurrence, and } \\
\text { poor survival }\end{array}$ & KPNA2 & $\begin{array}{c}\text { Inhibits cell proliferation, migration, spheroid } \\
\text { formation, and EMT in vitro and tumor growth and } \\
\text { lung metastasis in vivo }\end{array}$ & {$[131,132]$} \\
\hline $\operatorname{miR}-29 c-3 p$ & $\begin{array}{c}\text { Downregulated in EOC tissues compared to normal } \\
\text { ovarian tissues }\end{array}$ & ND & $\begin{array}{c}\text { Inhibits cell proliferation, invasion, migration, and } \\
\text { EMT in vitro }\end{array}$ & [173] \\
\hline miR-32 & $\begin{array}{c}\text { Downregulated in EOC tissues compared to adjacent normal } \\
\text { tissues and in recurrent EOC tissues compared to } \\
\text { primary tumors }\end{array}$ & BTLA & $\begin{array}{l}\text { Inhibits cell proliferation, migration, and invasion } \\
\text { in vitro }\end{array}$ & [174] \\
\hline miR-34a & $\begin{array}{l}\text { Downregulated in EOC tissues compared to paired adjacent } \\
\text { normal ovarian tissues; negatively associated with late stage }\end{array}$ & SNAI1 & $\begin{array}{l}\text { Inhibits cell invasion, EMT, spheroid formation, and } \\
\text { apoptosis in vitro }\end{array}$ & [175] \\
\hline miR-100 & $\begin{array}{l}\text { Downregulated in EOC tissues compared to matched adjacent } \\
\text { normal ovarian tissues; negatively associated with advanced } \\
\text { stage, lymph node metastasis, and poor survival }\end{array}$ & PLK1 & Inhibits cell proliferation in vitro & [176] \\
\hline miR-124 & $\begin{array}{c}\text { Downregulated in EOC tissues compared to normal ovarian } \\
\text { tissues, and lower in metastatic EOC tissues compared to } \\
\text { primary EOC tissues }\end{array}$ & $\begin{array}{l}\text { SPHK1 } \\
\text { PDCD6 }\end{array}$ & $\begin{array}{l}\text { Inhibits cell proliferation, colony formation, cell } \\
\text { invasion, and migration in vitro }\end{array}$ & {$[117,177]$} \\
\hline miR-130b & $\begin{array}{c}\text { Downregulated in EOC tissues compared to adjacent } \\
\text { non-tumor tissues }\end{array}$ & $\begin{array}{l}\text { ZEB1 } \\
\text { STAT3 }\end{array}$ & Inhibits cell invasion, migration, and EMT in vitro & [178] \\
\hline miR-133a & $\begin{array}{c}\text { Downregulated in EOC tissues compared to normal ovarian } \\
\text { tissues; negatively associated with late stage and lymph } \\
\text { node metastasis }\end{array}$ & ND & $\begin{array}{c}\text { Inhibits cell proliferation, invasion, and migration and } \\
\text { induces apoptosis in vitro }\end{array}$ & [179] \\
\hline miR-133a-3p & $\begin{array}{c}\text { Downregulated in EOC tissues compared to adjacent } \\
\text { non-tumor tissues }\end{array}$ & ND & Inhibits cell proliferation, invasion, and EMT in vitro & [180] \\
\hline $\operatorname{miR}-133 b$ & $\begin{array}{l}\text { Downregulated in EOC tissues compared to normal ovarian } \\
\text { epithelial tissues and benign ovarian cyst tissues; negatively } \\
\text { associated with tumor grade and lymph node metastasis }\end{array}$ & CTGF & Inhibits cell invasion, migration, and EMT in vitro & [181] \\
\hline miR-135a & $\begin{array}{l}\text { Downregulated in EOC tissues compared to ovarian } \\
\text { cystadenomas; negatively associated with stage, lymph node } \\
\text { metastasis, and poor survival }\end{array}$ & HOXA10 & $\begin{array}{l}\text { Inhibits cell proliferation and adhesion and promotes } \\
\text { apoptosis in vitro }\end{array}$ & [182] \\
\hline $\operatorname{miR}-135 a-3 p$ & $\begin{array}{l}\text { Downregulated in EOC tumors compared to paired adjacent } \\
\text { non-tumor tissues; negatively correlated with advanced stage } \\
\text { and poor OS }\end{array}$ & CCR2 & $\begin{array}{l}\text { Inhibits cell proliferation, migration, invasion, and } \\
\text { EMT in vitro and tumor growth and lung metastasis } \\
\text { in vivo }\end{array}$ & [183] \\
\hline
\end{tabular}


Table 1. Cont.

\begin{tabular}{|c|c|c|c|c|}
\hline $\begin{array}{l}\text { miRNA/ } \\
\text { miRNA Family }\end{array}$ & Altered Expression in EOC and Clinical Significance & Target Gene & In Vitro/In Vivo Effects & Citations \\
\hline miR-137 & $\begin{array}{l}\text { Downregulated in EOC tissues compared to paired } \\
\text { adjacent tissues }\end{array}$ & SNAI1 & $\begin{array}{l}\text { Inhibits cell invasion, spheroid formation, and EMT } \\
\text { in vitro }\end{array}$ & [175] \\
\hline $\operatorname{miR}-138$ & $\begin{array}{l}\text { Downregulated in EOC tissues compared to contralateral } \\
\text { normal ovarian tissues; negatively associated with lymph node } \\
\text { metastasis }\end{array}$ & $\begin{array}{l}\text { SOX4 } \\
\text { HIF1A } \\
\text { SOX12 } \\
\text { LIMK1 }\end{array}$ & $\begin{array}{l}\text { Inhibits cell proliferation and invasion in vitro and } \\
\text { tumor metastasis in the orthotopic xenograft mouse } \\
\text { model }\end{array}$ & {$[83,184,185]$} \\
\hline miR-139 & $\begin{array}{c}\text { Downregulated in EOC tissues compared to paired adjacent } \\
\text { normal tissues }\end{array}$ & $H D G F$ & $\begin{array}{l}\text { Inhibits cell proliferation, migration, and invasion } \\
\text { in vitro }\end{array}$ & [186] \\
\hline miR-139-3p & $\begin{array}{c}\text { Downregulated in EOC compared to adjacent normal ovarian; } \\
\text { negatively associated with advanced stage, lymph node } \\
\text { metastasis, and poor survival }\end{array}$ & ELAVL1 & $\begin{array}{l}\text { Inhibits cell proliferation, colony formation, invasion, } \\
\text { and migration in vitro and tumor growth and lung } \\
\text { metastasis in vivo }\end{array}$ & [187] \\
\hline miR-139-5p & $\begin{array}{c}\text { Downregulated in EOC tissues compared to precancerous } \\
\text { tissues; negatively associated with stage, lymph node } \\
\text { metastasis and poor survival }\end{array}$ & ROCK2 & $\begin{array}{l}\text { Inhibits cell proliferation, colony formation, migration, } \\
\text { and invasion in vitro and tumor growth in vivo }\end{array}$ & {$[188,189]$} \\
\hline miR-145-5p & $\begin{array}{c}\text { Downregulated in EOC tissues compared to paired adjacent } \\
\text { normal ovarian tissues }\end{array}$ & SMAD4 & $\begin{array}{l}\text { Inhibits cell proliferation and migration and promotes } \\
\text { apoptosis in vitro }\end{array}$ & [190] \\
\hline $\operatorname{miR}-148 a-3 p$ & $\begin{array}{c}\text { Downregulated in EOC tissues compared to adjacent } \\
\text { non-tumor tissues }\end{array}$ & ROCK1 & $\begin{array}{l}\text { Inhibits cell proliferation, invasion, and migration } \\
\text { in vitro, as well as tumor growth in vivo }\end{array}$ & [114] \\
\hline miR-152 & $\begin{array}{l}\text { Downregulated in EOC tissues compared to paired adjacent } \\
\text { normal ovarian tissues }\end{array}$ & $\begin{array}{l}\text { ADAM17 } \\
\text { WNT1 } \\
\text { ERBB3 }\end{array}$ & $\begin{array}{l}\text { Inhibits cell proliferation, invasion, migration, and } \\
\text { EMT in vitro }\end{array}$ & {$[178,191]$} \\
\hline miR-150 & $\begin{array}{l}\text { Downregulated in EOC tissues compared to normal ovarian } \\
\text { tissues; negatively correlated with advanced tumor stage and } \\
\text { grade and poor survival }\end{array}$ & ZEB1 & $\begin{array}{l}\text { Inhibits cell proliferation, invasion, migration, EMT, } \\
\text { and spheroid formation in vitro }\end{array}$ & {$[133,192]$} \\
\hline miR-186 & $\begin{array}{l}\text { Downregulated in cisplatin-resistant EOC cells compared to } \\
\text { cisplatin-sensitive EOC cells; decreased expression is associated } \\
\text { poor OS }\end{array}$ & TWIST1 & $\begin{array}{l}\text { Inhibits cell proliferation, invasion, migration, and } \\
\text { EMT in vitro and tumor growth and EMT in vivo }\end{array}$ & [193] \\
\hline miR-193b & $\begin{array}{l}\text { Downregulated in EOC compared to matched adjacent normal } \\
\text { ovarian tissues and in omental metastasis compared to paired } \\
\text { adjacent normal omentum; negatively correlated with stage, } \\
\text { grade, ascites, lymph node metastasis, tumor size, and poor } \\
\text { survival }\end{array}$ & $u P A$ & $\begin{array}{l}\text { Inhibits cell adhesion, proliferation, colony formation, } \\
\text { invasion and migration in vitro, and inhibits tumor } \\
\text { growth and metastasis in the orthotopic xenograft } \\
\text { mouse model }\end{array}$ & {$[194,195]$} \\
\hline
\end{tabular}


Table 1. Cont

\begin{tabular}{|c|c|c|c|c|}
\hline $\begin{array}{l}\text { miRNA/ } \\
\text { miRNA Family }\end{array}$ & Altered Expression in EOC and Clinical Significance & Target Gene & In Vitro/In Vivo Effects & Citations \\
\hline miR-199a-5p & $\begin{array}{l}\text { Downregulated in EOC cells under hypoxia compared to in } \\
\text { normoxic condition }\end{array}$ & $\begin{array}{l}\text { HIF1A } \\
\text { HIF2A }\end{array}$ & $\begin{array}{l}\text { Inhibits cell migration in vitro and inhibits tumor } \\
\text { growth and peritoneal seeding in vivo }\end{array}$ & [94] \\
\hline miR-202-5p & $\begin{array}{l}\text { Downregulated in EOC tissues compared to paired adjacent } \\
\text { normal ovarian tissues; positively associated with } \\
\text { patient survival }\end{array}$ & HOXB2 & $\begin{array}{l}\text { Inhibits cell proliferation, invasion, migration, and } \\
\text { EMT in vitro }\end{array}$ & [196] \\
\hline miR-206 & $\begin{array}{l}\text { Downregulated in EOC tissues compared to noncancerous } \\
\text { glioma tissues; negatively associated with lymph node and } \\
\text { distant metastasis }\end{array}$ & $\begin{array}{l}c-M E T \\
C C N D 1 \\
C C N D 2\end{array}$ & $\begin{array}{l}\text { Suppresses cell proliferation, migration, and invasion } \\
\text { in vitro }\end{array}$ & {$[197,198]$} \\
\hline miR-208a-5p & $\begin{array}{c}\text { Downregulated in metastatic EOC tissues compared to } \\
\text { nonmetastatic EOC tissues }\end{array}$ & DAAM1 & $\begin{array}{l}\text { Inhibits cell invasion, migration, and microfilaments } \\
\text { formation in vitro }\end{array}$ & [82] \\
\hline $\operatorname{miR}-215$ & $\begin{array}{l}\text { Downregulated in EOC tissues compared to adjacent normal; } \\
\text { negatively associated with stage and lymph node metastasis }\end{array}$ & NOB1 & $\begin{array}{l}\text { Inhibits cell proliferation, colony formation, migration, } \\
\text { and invasion in vitro and tumor growth in vivo. }\end{array}$ & [199] \\
\hline $\operatorname{miR}-217$ & $\begin{array}{l}\text { Downregulated in EOC tissues compared to paired adjacent } \\
\text { normal ovarian tissues; negatively associated with stage, } \\
\text { histological grade, and lymph node metastasis }\end{array}$ & $\begin{array}{l}\text { IGF1R } \\
\text { IL6 }\end{array}$ & $\begin{array}{l}\text { Inhibits cell proliferation, colony formation, invasion, } \\
\text { and migration, and reduces M0 macrophages } \\
\text { differentiation in vitro and tumor growth in vivo }\end{array}$ & {$[105,200]$} \\
\hline $\operatorname{miR}-218$ & $\begin{array}{l}\text { Downregulated in EOC tissues compared to adjacent normal; } \\
\text { negatively associated with stage and lymph node metastasis }\end{array}$ & RUNX2 & $\begin{array}{l}\text { Inhibits cell proliferation, colony formation, invasion, } \\
\text { and migration in vitro and tumor growth in vivo }\end{array}$ & [201] \\
\hline miR-219-5p & Decreased in EOC tissues compared to adjacent normal tissues & $\begin{array}{l}\text { TWIST1 } \\
\text { HMGA2 }\end{array}$ & $\begin{array}{l}\text { Inhibits cell proliferation, invasion, and migration } \\
\text { in vitro and tumor growth in vivo }\end{array}$ & {$[202,203]$} \\
\hline miR-335 & $\begin{array}{l}\text { Downregulated in EOC tissues compared to normal ovarian } \\
\text { tissues, in omental metastatic tissues compared to primary } \\
\text { tumors; negatively associated with poor survival and recurrence }\end{array}$ & ND & ND & [204] \\
\hline miR-338-3p & $\begin{array}{l}\text { Downregulated in EOC tissues compared to normal fallopian } \\
\text { samples based on TCGA database; negatively associated with } \\
\text { stage, grade, and metastasis }\end{array}$ & $\begin{array}{l}\text { MACC1 } \\
\text { RUNX2 }\end{array}$ & $\begin{array}{l}\text { Inhibits cell proliferation, colony formation, invasion, } \\
\text { migration, and EMT in vitro and tumor growth and } \\
\text { metastasis in vivo }\end{array}$ & {$[70,205,206]$} \\
\hline $\operatorname{miR}-340$ & $\begin{array}{c}\text { Downregulated in EOC tissues compared to normal } \\
\text { adjacent ovarian }\end{array}$ & $\begin{array}{l}\text { FHL2 } \\
\text { NFKB1 }\end{array}$ & $\begin{array}{c}\text { Inhibits cell proliferation, invasion, and migration } \\
\text { in vitro and tumor growth and intraperitoneal } \\
\text { metastasis in vivo }\end{array}$ & {$[207,208]$} \\
\hline
\end{tabular}


Table 1. Cont

\begin{tabular}{|c|c|c|c|c|}
\hline $\begin{array}{l}\text { miRNA/ } \\
\text { miRNA Family }\end{array}$ & Altered Expression in EOC and Clinical Significance & Target Gene & In Vitro/In Vivo Effects & Citations \\
\hline $\operatorname{miR}-363$ & $\begin{array}{c}\text { Downregulated in EOC compared to paired adjacent normal } \\
\text { ovarian tissues; negatively associated with advanced stage, } \\
\text { lymph node metastasis, and poor prognosis }\end{array}$ & NOB1 & $\begin{array}{l}\text { Inhibits cell proliferation, colony formation, invasion, } \\
\text { and migration in vitro and tumor growth in vivo }\end{array}$ & [209] \\
\hline miR-365 & $\begin{array}{c}\text { Downregulated in EOC tissues compared to adjacent normal } \\
\text { ovarian tissues; negatively associated with stage, grade, and } \\
\text { lymph node metastasis }\end{array}$ & WNT5A & $\begin{array}{c}\text { Inhibits cell proliferation, colony formation, invasion, } \\
\text { migration, and EMT in vitro, and tumor growth } \\
\text { in vivo }\end{array}$ & [210] \\
\hline $\operatorname{miR}-373$ & $\begin{array}{l}\text { Downregulated in EOC tumors compared to benign epithelial } \\
\text { ovarian tumors }\end{array}$ & $R A B 22 A$ & $\begin{array}{l}\text { Inhibits cell invasion, migration and EMT in vitro and } \\
\text { peritoneal metastasis in vivo }\end{array}$ & {$[211,212]$} \\
\hline $\operatorname{miR}-375$ & $\begin{array}{c}\text { Downregulated EOC tissues compared to normal } \\
\text { ovarian tissues }\end{array}$ & YAP1 & $\begin{array}{l}\text { Inhibits cell proliferation, invasion, migration, and } \\
\text { EMT in vitro and tumor growth, metastasis, and EMT } \\
\text { in vivo }\end{array}$ & [115] \\
\hline miR-377 & $\begin{array}{l}\text { Downregulated in EOC tissues compared to adjacent normal } \\
\text { ovarian tissues; positively correlated with survival }\end{array}$ & CUL4A & $\begin{array}{c}\text { Suppresses cell proliferation, invasion, migration, and } \\
\text { EMT in vitro }\end{array}$ & [213] \\
\hline $\operatorname{miR}-494$ & $\begin{array}{l}\text { Downregulated in EOC tissues compared to normal adjacent } \\
\text { tissues; negatively associated with stage, tumor size, and lymph } \\
\text { node metastasis }\end{array}$ & SIRT1 & $\begin{array}{l}\text { Inhibits cell proliferation, invasion, and migration } \\
\text { in vitro }\end{array}$ & [214] \\
\hline $\mathrm{miR}-378 \mathrm{~g}$ & $\begin{array}{c}\text { Downregulated in EOC tissues compared to normal } \\
\text { ovarian tissues }\end{array}$ & CHI3L1 & $\begin{array}{l}\text { Inhibits cell proliferation, migration, and } \\
\text { TGF- } \beta 1 \text {-induced EMT in vitro }\end{array}$ & [215] \\
\hline $\operatorname{miR}-421$ & ND & PDGFRA & $\begin{array}{l}\text { Inhibits cell proliferation, invasion, and tubule } \\
\text { formation in vitro, and tumor growth and } \\
\text { angiogenesis in vivo }\end{array}$ & [216] \\
\hline $\operatorname{miR}-448$ & $\begin{array}{c}\text { Downregulated in EOC tissues compared to adjacent normal } \\
\text { ovarian tissues }\end{array}$ & CXCL12 & $\begin{array}{l}\text { Inhibits cell proliferation, migration and invasion } \\
\text { in vitro and tumor growth in vivo }\end{array}$ & [99] \\
\hline miR-450a & $\begin{array}{c}\text { Downregulated in EOC tissues compared to normal } \\
\text { ovarian tissues }\end{array}$ & $\begin{array}{l}\text { TIMMDC1 } \\
\text { MT-ND2 } \\
\text { ACO2 } \\
\text { ATP5B }\end{array}$ & $\begin{array}{l}\text { Inhibits cell clonogenicity, invasion, migration, and } \\
\text { EMT and promotes anoikis in vitro and } \\
\text { intraperitoneal tumor growth in vivo }\end{array}$ & [217] \\
\hline $\operatorname{miR}-455$ & $\begin{array}{l}\text { Downregulated in EOC tissues compared to normal adjacent } \\
\text { tissues; negatively associated with stage, tumor size, and lymph } \\
\text { node metastasis }\end{array}$ & NOTCH1 & Inhibits cell proliferation and invasion in vitro & [218] \\
\hline
\end{tabular}


Table 1. Cont.

\begin{tabular}{|c|c|c|c|c|}
\hline $\begin{array}{l}\text { miRNA/ } \\
\text { miRNA Family }\end{array}$ & Altered Expression in EOC and Clinical Significance & Target Gene & In Vitro/In Vivo Effects & Citations \\
\hline $\operatorname{miR}-489$ & $\begin{array}{l}\text { Downregulated in EOC tissues compared to normal ovarian } \\
\text { tissues; negatively associated with poor survival, stage, grade, } \\
\text { lymph node, and distant metastasis }\end{array}$ & XIAP & $\begin{array}{l}\text { Inhibits cell proliferation, invasion, migration and } \\
\text { EMT in vitro }\end{array}$ & [219] \\
\hline miR-497 & $\begin{array}{l}\text { Downregulated in EOC tissues compared to normal ovarian } \\
\text { tissues; negatively associated with tumor stage, lymph node } \\
\text { metastasis, and poor survival }\end{array}$ & SMURF1 & Inhibition of cell migration and invasion in vitro & [220] \\
\hline miR-503-5p & $\begin{array}{l}\text { Downregulated in response to NF-kB pathway activation in } \\
\text { SKOV3 cells }\end{array}$ & CD97 & $\begin{array}{l}\text { Inhibits colony formation, migration and invasion } \\
\text { in vitro }\end{array}$ & [221] \\
\hline miR-506 & $\begin{array}{l}\text { Decreased expression is associated with stage and poor survival } \\
\text { in EOC }\end{array}$ & $\begin{array}{l}\text { SNAI2 } \\
\text { VIM } \\
\text { CDH2 }\end{array}$ & $\begin{array}{l}\text { Inhibits cell invasion, migration, and EMT in vitro, } \\
\text { and EMT, tumor growth, and metastasis in the } \\
\text { orthotopic xenograft mouse model }\end{array}$ & {$[63,222]$} \\
\hline miR-532-5p & $\begin{array}{l}\text { Downregulated in EOC compared to normal ovarian; } \\
\text { negatively associated with stage, grade, and distant metastasis }\end{array}$ & TWIST1 & $\begin{array}{l}\text { Inhibits cell proliferation, colony formation, and } \\
\text { invasion in vitro }\end{array}$ & [223] \\
\hline $\operatorname{miR}-548 \mathrm{c}$ & $\begin{array}{l}\text { Decreased in EOC tissues compared to normal ovarian tissues; } \\
\text { negatively associated with advanced stage and poor survival }\end{array}$ & TWIST1 & $\begin{array}{l}\text { Inhibits cell proliferation, migration, invasion, } \\
\text { stemness, and EMT in vitro }\end{array}$ & [224] \\
\hline miR-584 & $\begin{array}{c}\text { Downregulated in EOC tissues compared to paracancerous } \\
\text { tissues; negatively associated with distant and lymphatic } \\
\text { metastasis and poor survival }\end{array}$ & LPIN1 & $\begin{array}{l}\text { Inhibits cell proliferation, colony formation, and } \\
\text { migration in vitro }\end{array}$ & [225] \\
\hline miR-596 & ND & LETM1 & $\begin{array}{l}\text { Inhibits cell proliferation, invasion, and migration } \\
\text { in vitro and tumor growth in vivo }\end{array}$ & [226] \\
\hline $\operatorname{miR}-612$ & $\begin{array}{c}\text { Downregulated in EOC tissues compared to matched } \\
\text { non-tumor tissues }\end{array}$ & HOXA13 & $\begin{array}{l}\text { Inhibits cell proliferation, invasion, and migration, } \\
\text { and promotes apoptosis in vitro }\end{array}$ & [227] \\
\hline miR-654-3p & Downregulated in EOC cells compared to IOSE80 cells & AKT3 & $\begin{array}{l}\text { Inhibits cell invasion, migration and sphere formation } \\
\text { in vitro and tumor growth in vivo }\end{array}$ & [228] \\
\hline miR-665 & Decreased in EOC tissues compared to normal ovarian tissues & HOXA10 & Inhibits cell proliferation and migration in vitro & [229] \\
\hline miR-708 & $\begin{array}{l}\text { Downregulated in EOC tissues compared to normal ovarian } \\
\text { tissues; negatively associated with stage }\end{array}$ & $R A P 1 B$ & $\begin{array}{l}\text { Inhibits cell invasion, migration, cell adhesion, and } \\
\text { EMT in vitro and tumor growth and metastasis in vivo }\end{array}$ & [81] \\
\hline
\end{tabular}


Table 1. Cont

\begin{tabular}{|c|c|c|c|c|}
\hline $\begin{array}{l}\text { miRNA/ } \\
\text { miRNA Family }\end{array}$ & Altered Expression in EOC and Clinical Significance & Target Gene & In Vitro/In Vivo Effects & Citations \\
\hline $\mathrm{miR}-874-3 \mathrm{p} / 5 \mathrm{p}$ & $\begin{array}{c}\text { Downregulated in EOC tissues compared to normal ovarian } \\
\text { epithelial tissues }\end{array}$ & SIK2 & $\begin{array}{c}\text { Inhibits cell proliferation, colony formation, invasion, } \\
\text { and migration in vitro }\end{array}$ & [230] \\
\hline $\operatorname{miR}-936$ & $\begin{array}{c}\text { Downregulated in EOC tissues compared to adjacent normal } \\
\text { tissues; negatively associated with tumor size, stage, and } \\
\text { lymphatic metastasis }\end{array}$ & FGF2 & $\begin{array}{l}\text { Inhibits cell proliferation, invasion, and migration } \\
\text { in vitro and tumor growth in vivo. }\end{array}$ & [231] \\
\hline $\operatorname{miR}-4454$ & $\begin{array}{l}\text { Downregulated in metastatic EOC tissues compared to primary } \\
\text { EOC tissues; positively associated with patient survival }\end{array}$ & $\begin{array}{l}\text { SPARC } \\
\text { BAG5 }\end{array}$ & $\begin{array}{c}\text { Inhibits cell proliferation, colony formation, migration, } \\
\text { and invasion in vitro, and peritoneal metastasis } \\
\text { in vivo. }\end{array}$ & [232] \\
\hline miR-6089 & Downregulated in EOC tissues compared to paratumor tissues & МҮH9 & $\begin{array}{l}\text { Suppresses cell proliferation, migration, invasion, and } \\
\text { EMT in vitro, and tumor growth and metastasis } \\
\text { in vivo }\end{array}$ & [233] \\
\hline $\operatorname{miR}-6126$ & $\begin{array}{l}\text { Downregulated in EOC tissues compared to normal ovarian } \\
\text { tissues; inversely correlated with tumor progression and } \\
\text { positively associated with survival }\end{array}$ & ITGB1 & $\begin{array}{l}\text { Inhibits cell invasion, migration, and tube formation } \\
\text { in vitro and angiogenesis and tumor growth in the } \\
\text { orthotopic xenograft mouse model }\end{array}$ & [234] \\
\hline \multicolumn{5}{|c|}{ miRNAs down-regulated in secreted exosomes and circulating body fluids } \\
\hline $\operatorname{miR}-125 a$ & $\begin{array}{l}\text { Downregulated in serum of EOC patients compared to healthy } \\
\text { controls }\end{array}$ & $\begin{array}{l}\text { GALNT14 } \\
\text { ARID3B }\end{array}$ & Inhibits cell proliferation, invasion, and EMT in vitro & {$[235,236]$} \\
\hline $\operatorname{miR}-125 b$ & $\begin{array}{l}\text { Downregulated in tissues and serum of EOC patients compared } \\
\text { to adjacent normal ovarian tissues and serum of healthy control } \\
\text { respectively; negatively associated with stage and lymph node } \\
\text { and distant metastasis }\end{array}$ & $\begin{array}{l}S E T \\
G A B 2\end{array}$ & $\begin{array}{l}\text { Inhibits cell invasion, migration, and EMT in vitro and } \\
\text { metastasis in vivo }\end{array}$ & $\begin{array}{c}{[113,237,} \\
238]\end{array}$ \\
\hline miR-212 & $\begin{array}{l}\text { Downregulated in EOC tissues and serum compared to paired } \\
\text { adjacent normal ovarian tissues and healthy controls } \\
\text { respectively; negatively correlated with tumor stage } \\
\text { and metastasis }\end{array}$ & HBEGF & $\begin{array}{l}\text { Inhibits cell proliferation, invasion, and migration } \\
\text { in vitro }\end{array}$ & [239] \\
\hline miR-122 & $\begin{array}{c}\text { Downregulated in serum of serous EOC patients compared to } \\
\text { benign controls }\end{array}$ & P4HA1 & $\begin{array}{l}\text { Inhibits cell invasion, migration, and EMT in vitro, } \\
\text { and intraperitoneal metastasis in vivo }\end{array}$ & {$[127,240]$} \\
\hline miR-148a & $\begin{array}{l}\text { Downregulated in plasma of EOC patients compared to healthy } \\
\text { controls; negatively associated with tumor grade, stage, lymph } \\
\text { node metastasis, and poor survival }\end{array}$ & ND & $\begin{array}{l}\text { Inhibits cell proliferation, invasion, and migration } \\
\text { in vitro }\end{array}$ & [241] \\
\hline
\end{tabular}


Table 1. Cont.

\begin{tabular}{|c|c|c|c|c|}
\hline $\begin{array}{l}\text { miRNA/ } \\
\text { miRNA Family }\end{array}$ & Altered Expression in EOC and Clinical Significance & Target Gene & In Vitro/In Vivo Effects & Citations \\
\hline miR-199a & $\begin{array}{l}\text { Downregulated in serum of EOC patients compared to normal } \\
\text { controls; negatively associated with tumor grade, lymph node } \\
\text { and distant metastasis, and poor survival }\end{array}$ & ND & ND & [128] \\
\hline \multicolumn{5}{|c|}{ miRNAs with both pro- and anti-metastatic effects } \\
\hline \multirow{2}{*}{$\operatorname{miR}-9$} & $\begin{array}{l}\text { Upregulated in metastatic EOC tissues compared to paired } \\
\text { primary EOC tissues }\end{array}$ & $\mathrm{CDH1}$ & Promotes cell migration, invasion, and EMT in vitro & [242] \\
\hline & $\begin{array}{l}\text { Downregulated in recurrent serous EOC tissues compared to } \\
\text { primary EOC tissues }\end{array}$ & TLN1 & $\begin{array}{l}\text { Inhibits cell proliferation, migration, and invasion } \\
\text { in vitro }\end{array}$ & {$[243,244]$} \\
\hline \multirow[t]{2}{*}{$\operatorname{miR}-141$} & $\begin{array}{l}\text { Upregulated in EOC tissues compared to normal ovarian } \\
\text { tissues, and serum of EOC patients compared to healthy } \\
\text { controls; positively associated with tumor stage, lymph node } \\
\text { metastasis, and poor survival }\end{array}$ & $\begin{array}{l}\text { KLF12 } \\
\text { SIK1 } \\
\text { MAPK14 }\end{array}$ & $\begin{array}{l}\text { Promotes proliferation, anoikis resistance, and } \\
\text { survival in vitro, and tumor growth and metastasis } \\
\text { in vivo }\end{array}$ & $\begin{array}{c}{[126,245,} \\
246]\end{array}$ \\
\hline & $\begin{array}{l}\text { Downregulated in integrated mesenchymal subtype of EOC } \\
\text { compared to normal ovarian epithelial tissues }\end{array}$ & ND & Inhibits cell migration, invasion, and EMT in vitro & {$[222,247]$} \\
\hline \multirow{2}{*}{ miR-200a } & $\begin{array}{c}\text { Upregulated in EOC tumors compared to normal ovarian } \\
\text { tissues and in serum of EOC patients compared to healthy } \\
\text { controls; positively associated with aggressiveness, late stage, } \\
\text { and lymph node metastasis }\end{array}$ & $\begin{array}{l}\text { PTEN } \\
\text { MAPK14 }\end{array}$ & Promotes cell migration and invasion in vitro & $\begin{array}{c}{[126,246,} \\
248]\end{array}$ \\
\hline & $\begin{array}{l}\text { Downregulated in vasculogenic mimicry positive EOC tissues } \\
\text { compared to vascular mimicry negative ovarian tissues and in } \\
\text { integrated mesenchymal subtype compared to ovarian normal } \\
\text { epithelial tissues; negatively associated with stage, ascites, and } \\
\text { metastasis and positively correlated with patient survival }\end{array}$ & $\begin{array}{l}\text { IL8 } \\
\text { CXCL1 } \\
\text { EPHA2 }\end{array}$ & $\begin{array}{l}\text { Inhibits tube formation, vasculogenic mimicry, and } \\
\text { cell invasion in vitro, and angiogenesis and metastasis } \\
\text { in vivo }\end{array}$ & $\begin{array}{c}{[222,249,} \\
250]\end{array}$ \\
\hline \multirow{2}{*}{$\mathrm{miR}-200 \mathrm{~b}$} & $\begin{array}{l}\text { Upregulated serum of EOC patients compared to healthy } \\
\text { controls; positively associated with tumor stage, lymph node } \\
\text { metastasis, and poor survival }\end{array}$ & ND & ND & [126] \\
\hline & $\begin{array}{l}\text { Downregulated in vasculogenic mimicry positive EOC tissues } \\
\text { compared to vascular mimicry negative ovarian tissues; } \\
\text { negatively associated with stage, ascites, and metastasis and } \\
\text { positively correlated with patient survival }\end{array}$ & $\begin{array}{l}\text { IL8 } \\
\text { CXCL1 }\end{array}$ & $\begin{array}{l}\text { Inhibits tube formation, vasculogenic mimicry, and } \\
\text { cell invasion in vitro, and angiogenesis and metastasis } \\
\text { in vivo }\end{array}$ & [249] \\
\hline
\end{tabular}


Table 1. Cont.

\begin{tabular}{|c|c|c|c|c|}
\hline $\begin{array}{l}\text { miRNA/ } \\
\text { miRNA Family }\end{array}$ & Altered Expression in EOC and Clinical Significance & Target Gene & In Vitro/In Vivo Effects & Citations \\
\hline \multirow{2}{*}{ miR-200c } & $\begin{array}{l}\text { Upregulated in SOC tissues and serum of EOC patients } \\
\text { compared to heathy controls; associated with tumor stage, } \\
\text { lymph node metastasis, and poor survival }\end{array}$ & ND & ND & {$[126,251]$} \\
\hline & $\begin{array}{c}\text { Upregulated in EOC tumors compared to normal ovarian } \\
\text { tissues; inversely associated with tumor stage and lymph node } \\
\text { metastasis }\end{array}$ & $\begin{array}{l}\text { ZEB2 } \\
\text { TUBB3 }\end{array}$ & Inhibits cell migration and invasion in vitro & {$[252,253]$} \\
\hline \multirow{2}{*}{ miR-203 } & $\begin{array}{l}\text { Upregulated in EOC tissues compared with adjacent } \\
\text { normal tissues }\end{array}$ & PDHB & $\begin{array}{l}\text { Promotes cell proliferation, migration, and glycolysis } \\
\text { in vitro, and tumor metastasis in vivo }\end{array}$ & [118] \\
\hline & $\begin{array}{l}\text { Downregulated in SOC tissues compared to adjacent normal } \\
\text { ovarian tissue; positively associated with patient survival }\end{array}$ & $\begin{array}{l}\text { SNAI2 } \\
\text { BIRC5 }\end{array}$ & $\begin{array}{l}\text { Inhibits cell proliferation, invasion, migration, and } \\
\text { EMT in vitro, and tumor growth in vivo }\end{array}$ & {$[119,254]$} \\
\hline
\end{tabular}




\subsection{Dysregulations of miRNAs by Genetic and Epigenetic Alterations}

Genetic alteration is one of the mechanisms underlying the dysregulation of miRNAs in cells. Using high-resolution array comparative genomic hybridization (aCGH), Zhang et al. revealed that $37.1 \%$ of genomic regions containing miRNA genes showed DNA copy number variations in EOC [255]. Among the miRNA genes analyzed, 21 out of 47 intronic miRNA genes showed high degrees of copy number variations. Further analyses showed that dysregulation of most of these miRNAs was associated with DNA copy number abnormalities [255]. Downregulation of let-7a3 was correlated with a loss of DNA copy number while upregulation of miR-9-1 and miR-213 was associated with a gain of DNA copy number [255]. Similarly, 3q26 amplification has been detected frequently in HGSC [143]. One of the miRNA precursors located in this region, mir-551b, is amplified in $1 / 3$ of HGSC patients. The dominant form of its mature miRNA, miR-551b-3p, is also elevated in HGSC tissues compared to normal ovarian tissue and associated with poor prognosis. Furthermore, $32 \%$ of CCC patients showed 17q23-25 amplification which contains mir-21 gene [256]. Although the correlation of 17q23-25 amplification and miR-21 overexpression is low, the presence of 17q23-25 amplification increased miR-21 overexpression in the CCC cases by $25 \%$. These studies suggest that alteration of DNA copy number contributes to the dysregulation of some miRNAs.

Alteration in the methylation of $\mathrm{CpG}$ islands in miRNA gene promoters has also been linked to the dysregulation of miRNAs in EOC. Analysis of two datasets from GEO showed that miR-340 was downregulated in EOC tissues [207]. Interrogation of the 2-kb region upstream of mir-340 by EMBOSS in EOC cells revealed three CpG islands. In addition, treatment with methylation inhibitors, 5-Aza-dC or TSA, increased the levels of miR-340 in EOC cells, suggesting that the downregulation of miR-340 is due to hypermethylation of its promoter [207]. Hypermethylation in the CpG islands of multiple miRNA genes, including mir-124a-2, mir-127, mir-125b-1, mir-129-2, mir-137, mir-193a, mir-203a, mir-34b/c, mir-130b, mir-1258, mir-9-1, mir-9-3, mir-107, mir-130b, mir-124-3, mir-339, and mir-375, has also been found in EOC tumors compared to the paired normal ovarian tissues [116,257,258]. A strong correlation between hypermethylation and downregulation in miR-125b-5p, miR-129-5p, miR-132-3p, miR-137, and miR-193a-5p was also observed [116]. Interestingly, hypermethylation of mir-125b-1, mir-137, mir-34b/c, mir-203a, mir-130b, and mir-375 is associated with metastasis [116,257]. Similarly, hypomethylation in mir-21, mir-203, mir-205, and mir-191 promoters has been reported in EOC tissues with the association with their overexpression $[116,120]$. Thus, hypomethylation and hypermethylation of the promoter regions of miRNA genes play an important role in the aberrant expression of miRNAs.

\subsection{Dysregulation of miRNAs by Alteration in miRNA Biogenesis}

The first step of miRNA biogenesis is the transcription of the pri-miRNAs. As a consequence, dysregulation of factors that regulate transcription in general may lead to a change in the abundance of mature miRNA. p53, whose mutations occur in 96\% of cases of HGSC [259], promotes the expression of miR-145 and miR-34b/c, and mutations of p53 are associated with lower expression of these miRNAs $[161,259,260]$. In addition, it has been demonstrated that c-Myb binds directly to the promoter of mir-520h to induce its expression [130]. c-Myb has been reported to be upregulated in EOC tissues compared to aged-matched control tissues and activation of TGF- $\beta$ signaling induced upregulation of c-Myb and miR-520h [130,261]. Similarly, PPAR $\gamma$ response elements (PPRE) have been identified in the mir-125b promoter and activation of PPAR $\gamma$ leads to an increase in miR-125b levels [262]. However, miR-125b is reported to be downregulated [262] while PPAR $\gamma$ is upregulated [263] in EOC tissues compared to normal ovarian tissues. Despite of the upregulation, PPAR $\gamma$ was shown to inhibit proliferation and induce apoptosis by modulating p63 and p73 upregulation [264]. Therefore, it is unclear if PPAR $\gamma$ contributes to the downregulation of miR-125b. On the other hand, several transcription factors have been shown to inhibit miRNA expression. Overexpression of an ETS transcription factor, PEA3, or its activation by EGF signaling, significantly reduced pri-miR-125a and mature miR-125a levels and the binding of PEA3 to the mir-125a promoter has been confirmed by ChIP analysis [236]. Similarly, miR-6089 transcription was found to be directly inhibited by c-Jun 
which is activated by MYH9 via the Wnt/ $\beta$-catenin signaling pathway [233]. Aberrant activation of EGFR and Wnt/ $\beta$-catenin signaling is well documented in EOC $[66,265]$. Therefore, it is possible that the hyperactivation of these signaling pathways contributes to the downregulation of miR-125a and miR-6089, respectively.

Once transcribed, pri-miRNAs are processed into pre-miRNAs and finally mature miRNAs. These processing events are critical rate-limiting steps that regulate the levels of mature miRNAs within cells [38]. Abnormalities in DNA copy number of DICER1 and AGO2 have been detected in 32.7\% and $57.4 \%$ of primary EOC tumors, respectively [255]. In addition, single-nucleotide mutations were found in DICER1 and DROSHA genes [266]; however, the functional roles of these mutations are unclear. Lower mRNA levels of DICER and DROSHA were detected in $60 \%$ and $51 \%$, respectively, of EOC tumors examined and associated with advanced tumor stage and of EOC patients [266]. DDX1, an RNA-binding protein that was identified to associate with the microprocessor complex, has been reported to play a key role in miRNA processing $[21,267,268]$. Low DDX1 expression is significantly associated with poor overall survival of serous EOC [269]. Silencing of DDX1 reduced the levels of mature miR-200a, miR-29c, miR-141, and miR-101 [269]. Interestingly, phosphorylation of DDX1 by the protein kinase Ataxia telangiectasia mutated (ATM) in response to DNA damage enhanced pri-miRNA processing [269]. Dicer, DROSHA, AGO2, and cofactors play critical roles in the controlled expression of mature miRNAs, and their dysregulation can lead to abnormal miRNA levels. Further investigation on the dysregulation of these components and their effects on specific miRNA expression levels would provide an insight into the mechanisms of miRNA dysregulation in EOC.

Single-nucleotide polymorphisms found in miRNAs, referred to as miRSNPs, may also contribute to the alteration of mature miRNA levels. The genetic variant rs11614913 of miR-196a-2 has been detected in multiple cancer types, including gastric [270], head and neck cancer [271], and breast cancer [272]. Genotype distribution analysis of miR-196a-2 polymorphism revealed that CT and CC genotypes are frequently observed in EOC patients [273]. In addition, the recessive genetic model indicated that the risk of EOC is higher in CC genotype carriers compared to the ones carrying wild-type homozygous TT and CT alleles. Furthermore, it was shown that miR-196a-2 rs11614913 influenced the production of mature miR-196a-2. There was a significant upregulation of mature miR-196a-2 detected in the CC genotype compared to the TT genotype of EOC tissue samples [273]. However, a recent study showed no significant difference in the frequency of miR-196a-2 rs11614913 in HGSC patients compared to healthy controls [274]. Therefore, whether miR-196a-2 rs11614913 variant is a risk factor in EOC requires further study.

\section{Roles of miRNAs in Ovarian Cancer Metastasis}

Numerous studies have reported the functions of miRNAs in EMT, cell migration, invasion, and metastasis in EOC. In addition, miRNAs also participate in inducing angiogenesis and modulating tumor microenvironments $[102,105,106]$, which contribute to tumor metastasis (Figure 2). The majority of studied miRNAs exert negative regulatory effects on metastasis, while some miRNAs serve as positive regulators of metastasis. In addition, some miRNAs have been reported to exhibit both pro-metastatic and anti-metastatic effects, probably depending on the genes they targeted under different cancer contexts. 


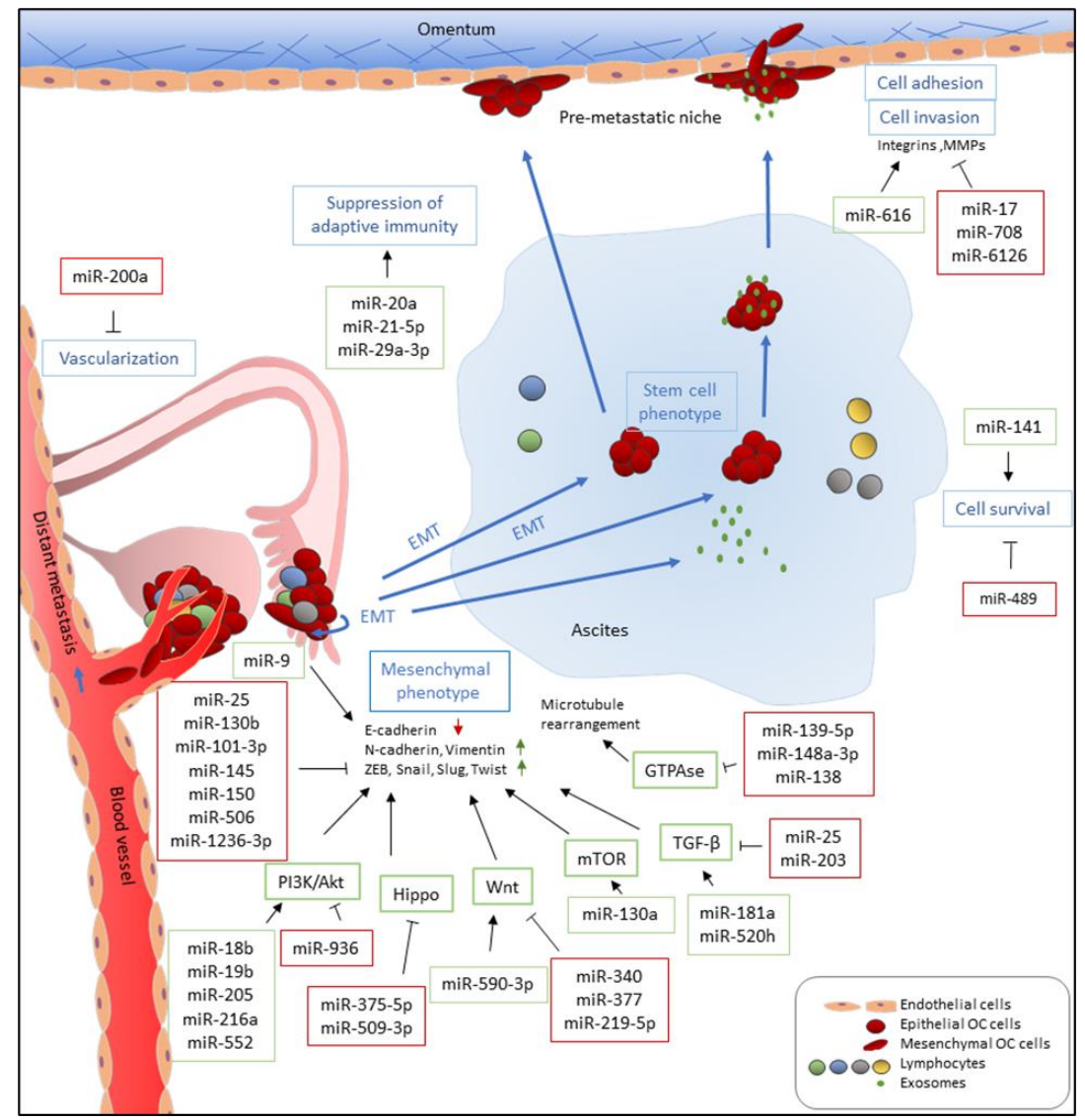

Figure 2. Functions of miRNAs in EOC metastasis. miRNAs which are upregulated and promote metastasis-related processes are depicted in green boxes while downregulated miRNAs which inhibit metastatic-related processes are listed in red boxes. miRNAs directly and indirectly regulate epithelial-to-mesenchymal transition (EMT) by targeting E-cadherin and E-cadherin repressors, such as ZEB, Snail, Slug, and Twist, and associated signaling pathways. miR-9 directly targets E-cadherin to activate EMT while miR-25, miR-101-3p, miR-130b, miR-145, miR-150, and miR-1236-3b directly inhibit expression of E-cadherin repressors, including ZEB1, SNAI2, and TWIST1. Multiple miRNAs, such as miR-18b, miR-19b, miR-205, miR-216b, and miR-552, promote EMT by targeting PTEN, leading to the activation of the PI3K/AKT pathway. In addition, upregulation of miR-590-3p, miR-130a, miR-181a, and miR-520h induces Wnt, mTOR, and TGF- $\beta$ signaling, respectively, which are known pathways that promote EMT. In contrast, miR-936, miR-375-5p, miR-509-3p, miR-340, miR-377, miR-219-5p, miR-25, and miR-203 attenuate PI3K/AKT, Hippo, Wnt, and TGF- $\beta$ signaling pathways and inhibit cell migration, invasion, and EMT. Furthermore, downregulation of miR-139-5p, miR-148a-3p, and miR-138, which has been reported to inhibit ROCKs and LIMK1 expression, increases cell motility via GTPase signaling. Metastatic EOC cells float in ascites as single cells or spheroids which exhibit stem cell-like properties. To survive after detaching from primary site and inside ascites, metastatic EOC cells upregulate miR-141 and downregulate miR-489 to modulate anoikis resistance. In the transcoelomic pathway, EOC metastatic cells then adhere to the mesothelium lining and invade peritoneal organs. Upregulation of miR-616 and downregulation of miR-17 and miR-6126 increase cell adhesion via increased expression and activities of integrins and MMPs which recognize and degrade the extracellular matrix (ECM) of the mesothelial cells, respectively. In addition, downregulation of miR-708 increases focal adhesion formation through promoting focal adhesion kinase (FAK) activities. EOC metastasis occurs in an immune-suppressive environment which are modulated by miRNAs. miR-21-5p and miR-29a-3p promote adaptive immune suppression via upregulation of tumor-associated macrophages (TAMs) and induction Treg/Th17 imbalance while miR-20a downregulates MICA/B to avoid recognition by cytotoxic T-cells. Furthermore, EOC tumors increase vascularization and angiogenesis via downregulation of miR-200a, implicating them in distant metastasis through a perfusion pathway. 


\subsection{MicroRNAs that Promote Metastasis}

Multiple miRNAs have been reported to promote EOC metastasis by targeting CDH1 as well as its associated pathways, such as AKT, TGF- $\beta$, and Wnt/ $\beta$-catenin, to induce EMT. CDH1 is directly inhibited by miR-9, which was found to be upregulated in serous ovarian cancer tissues and cell lines [242]. Overexpression of miR-9 in EOC cells promoted migration and invasion, as well as upregulating the mesenchymal markers, N-cadherin and Vimentin [242]. Furthermore, overexpression of miR-181a enhanced, while inhibition of miR-181a reduced, EMT, migration, invasion, and chemoresistance in vitro by targeting SMAD7, which negatively regulates TGF- $\beta$ signaling [110]. Injection of miR-181a-overexpressing cells into the ovarian bursa of nude mice resulted in a significant increase in tumor burden and dissemination. These results, together with the findings that miR-181a is enriched in recurrent tumors compared to primary tumors and negatively correlated with patient survival [110], strongly suggest that miR-181a is a key regulator of EOC metastasis. Similarly, miR-520h targets $S M A D 7$, resulting in EMT and tumor growth promotion, as supported by in vitro and in vivo studies [130]. Meanwhile, miR-182 inhibits BRCA1, a tumor suppressor involved in DNA repair, and MTSS1, a metastasis suppressor [275], and upregulates the EMT promoter HMGA2, thus increasing EOC cell invasiveness in vitro and tumor metastasis in vivo [136]. miR-182 was also found to target a transcription factor FOXF2 and to exert promoting effects on EOC cell migration and invasion [148].

PTEN, a tumor suppressor that negatively regulates PI3K/AKT pathway [276], is targeted by several miRNAs that promote metastasis. Specifically, miR-18b [144], miR-19b [145], miR-205 [153], miR-216a [154], and miR-552 [155] have been reported to directly target PTEN and enhance cell migration, invasion, and/or EMT in vitro when these miRNAs are overexpressed, but reduced these properties when endogenous miRNAs were inhibited. In vivo, miR-205 overexpression resulted in the formation of a larger number of intraperitoneal tumors [153]. Other target genes have also been identified for miR-205. In the EC subtype, miR-205 is upregulated in tumors and its overexpression enhances cell migration and invasion by targeting ESRRG [141]. The effect of miR-205 on promoting EOC cell migration and invasion has also been confirmed by other studies [277,278]. miR-130a was discovered to target TSC1, a negative regulator of the mTOR pathway [279], and increased proliferation, invasion, and EMT in vitro, as well as tumor growth and metastasis in vivo [138]. Interestingly, miR-130a is upregulated in HGSC, and, in response to inflammatory stimuli, NFkB binds to the miR-130a promoter to induce its expression [138]. These findings suggest that a mechanism by which inflammation promotes EOC metastasis is to induce miR-130a expression, which, in turn, activates mTOR signaling.

Studies from our lab have shown that miR-590-3p is upregulated in EOC tumor tissues and plasma samples [112]. Overexpression of miR-590-3p promotes, while inhibition of miR-590-3p suppresses, EOC cell proliferation, migration, and invasion, as well as spheroid formation in 3D cultures in vitro [112,159]. Subcutaneous and intraperitoneal injection of EOC cells overexpressing miR-590-3p revealed that miR-590-3p promotes tumor growth and metastasis [112]. We further showed that FOXA2 is a direct target of miR-590-3p, while Versican (VCAN), a proteoglycan commonly overexpressed in cancer, is transcriptionally inhibited by FOXA2. Interestingly, we found that VCAN mRNA levels are positively correlated with vascular and lymphovascular invasion, and that low FOXA2/high VCAN is associated with poor patient survival [112]. In addition to FOXA2, miR-590-3p also targets cyclin $\mathrm{G} 2$ (CCNG2) and FOXO3. CCNG2 is an atypical cyclin that negatively regulates cell proliferation [280], migration, invasion, EMT, and tumor metastasis by suppressing Wnt/ $\beta$-catenin [281]. FOXO3 has been shown to activate CCNG2 transcription in EOC cells [282]. By targeting these two genes, miR-590-3p enhances $\beta$-catenin signaling [159]. These findings support the role of miR-590-3p in promoting EOC metastasis.

Matrix metalloproteinases (MMPs) play an important role in cell invasion and metastasis, and their activity is inhibited by tissue inhibitors of MMPs (TIMPs) [283]. It has been reported that miR-616 expression is positively correlated with EOC metastasis, advanced stage, poor differentiation, and lower patient survival, and its upregulation promotes invasion, migration, and EMT in vitro. TIMP2 
was identified as a direct target of miR-616. In addition, more lung metastatic nodules were observed when EOC cells transfected with miR-616 were injected through the tail vein into nude mice, suggesting that miR-616 promotes tumor metastasis [111].

Dicer, a key enzyme involved in miRNA biogenesis, was reported to be negatively correlated with advanced EOC stages and positively associated with better patient outcomes [266]. Rupaimoole et al. reported that DICER1 was targeted by miR-630 in EOC under hypoxic conditions [156]. In vitro studies showed that miR-630 induced migration and invasion, as well as EMT. In an orthotopic mouse model of ovarian cancer, delivery of miR-630 via liposomal nanoparticles significantly enhanced tumor growth and distant metastasis [156]. Interestingly, treatment with a combination of anti-miR-630 and anti-vascular endothelial growth factor (VEGF) antibody resulted in a strong reduction in tumor growth and metastasis [156], suggesting the therapeutic potential of this approach. Paradoxically, another study found that Dicer was overexpressed in ovarian tumor stromal cells and played a pro-inflammatory and pro-metastatic role by down-regulating miR-6780b, which inhibits the NFkB pathway in fibroblasts [284]. Thus, Dicer may exert cell type-specific effects on EOC metastasis.

Thrombocytosis was reported to be positively associated with advanced stage and grade of EOC. In addition, it is frequently observed in patients with lymph node metastases, increased volumes of ascites, and decreased overall survival [158,285]. Tang et al. discovered that when EOC cells were cocultured with platelet microparticles (PMP), there was an increase in cell proliferation, migration, and EMT, suggesting the induction of EMT from platelet-delivered molecules [158]. In addition, in vitro analysis showed that PMPs contained miR-939 which promoted EMT in EOC cells. Finally, the uptake of miRNA-containing PMPs by EOC cells was suggested to be mediated by secretory phospholipase A2 type IIA [158]. These studies showed a mechanistic link between thrombocytosis and EOC progression. However, how miR-939 induces EMT remains to be investigated.

The immune microenvironment is known to be involved in EOC progression, including metastasis. miRNAs may also play a role in promoting EOC metastasis by altering the immune microenvironment. miR-29a-3p and miR-21-5p increased the ratio of regulatory and helper $17 \mathrm{~T}$ cells (Treg/Th17) and tumor growth and metastasis in vivo [102]. A higher Treg/Th17 ratio was observed in EOC and in metastatic peritoneal tissues. Both miRNAs were present at high levels in exosomes released from M2 macrophages. STAT3, which is involved in immune cell differentiation, was identified to be inhibited by both miRNAs [102]. These findings suggest that miR-29a-3p and miR-21-5p induce an immunosuppressive microenvironment to facilitate EOC development in part by targeting STAT3. Unlike in immune cells, STAT3 exerts tumor-promoting effects on EOC cells [286]. Interestingly, miR-551-3b may bind directly to STAT3 promoter, leading to the recruitment of RNA polymerase II and transcription factor TWIST1, activating STAT3 transcription and promoting metastasis [143]. In addition, miR-551-3b promotes EOC stem cell proliferation, invasion, and chemoresistance by downregulating FOXO3 and TRIM31 [142]. Another instance of immune suppression is miR-20a, which may reduce natural killer cell cytotoxicity towards EOC cells by inhibiting MICA/B, resulting in immune evasion [106]. Serum levels of miR-20a were elevated in EOC subjects, with high expression associated with poor survival [106]. These studies provided insights into the role of miRNAs in cancer immune modulation.

\subsection{MicroRNAs that Suppress Metastasis}

\subsubsection{MicroRNAs Suppress Metastasis by Directly Targeting Transcription Factors that Regulate EMT Markers}

Master regulators of EMT, including ZEBs, SNAIs, and TWISTs, operate largely as transcription repressors to repress CDH1 transcription [287]. Overexpression of miR-101-3p, miR-130b, and miR-1236-3p inhibits EOC cell invasion and migration, increases E-cadherin, and decreases mesenchymal markers by directly targeting ZEB1 [165,168,178]. Similarly, SNAI1 and SNAI2 are targets of multiple miRNAs $[119,167,175,222]$. Using the TCGA database and tissue samples from EOC patients, Yang et al. identified miR-506 as a positive prognostic predictor of EOC patients [222]. MiR-506 was found to upregulate E-cadherin and downregulate SNAI2 and VIM, as well as inhibited cell invasion 
and migration. In addition to SNAI2, miR-506 also directly targeted VIM and CDH2 [63]. Furthermore, in vivo miR-506 delivery via nanoparticles reduced the number and weight of tumor nodules in the intraperitoneal metastasis model [222], providing strong evidence that miR-506 suppresses metastasis. On the other hand, miR-145 has been shown to interact with the 3' UTR of TWIST1 and SOX9 and exert inhibitory effects on EMT [193]. Importantly, when nude mice were inoculated intraperitoneally with miR-145-overexpressing EOC cells, there were fewer metastases and less ascites than the control mice [162]. These findings suggest that miR-145 suppresses metastasis and one of the possible mechanisms is to inhibit TWIST1 and, therefore, EMT. miR-25 has also been reported to target SNAI2 and inhibit TGF- $\beta$-induced EMT, cell migration, and invasion [167]. Through direct inhibition of EMT marker genes, these miRNAs suppress EMT and metastasis.

\subsubsection{MicroRNAs Suppress Metastasis by Targeting Growth Factors and Related Signaling Pathways}

Several miRNAs have been shown to modulate the metastatic potential of EOC cells by targeting growth factors and their downstream signaling pathways. Ectopic expression of miR-139, miR-212, and miR-936 inhibited cell proliferation, invasion, and migration by targeting hepatoma-derived growth factor (HDGF), heparin-binding epidermal growth factor (HBEGF), and fibroblast growth factor 2 (FGF2), respectively $[186,231,239]$. Moreover, Li et al. found that low miR-936 expression in EOC tissues was associated with large tumor size, advanced stage, and lymphatic metastasis. They also demonstrated that miR-936 inhibited tumor growth in vivo, as well as significantly deactivated the PI3K/AKT pathway shown by decreased p-PI3K and p-AKT levels [231]. Similarly, miR-217 directly targeted insulin-like growth factor 1 receptor (IGF1R) and suppressed EOC cell proliferation, colony formation, invasion, and migration, as well as inhibited subcutaneous tumor growth [200]. In addition, miR-421 directly targeted platelet derived growth factor receptor A (PDGFRA) and inhibited CD44+/CD133+ serous human ovarian cancer stem cell proliferation, invasion, angiogenesis, and tumor growth [216]. These findings suggest that miR-421 exerts an anti-metastatic effect by suppressing PDGF signaling. Finally, miR-503-5p targets CD97, a member of the epidermal growth factor-seven transmembrane (EGF-TM7) family that induces JAK2/STAT3 signaling $[288,289]$, to inhibit EOC cell proliferation, migration, and invasion [221].

Several anti-metastatic miRNAs have been reported to negatively regulate the Wnt signaling in EOC. Using EOC tissue samples and the TCGA database, Huang et al. and Yu et al. identified miR-340 and miR-377 as positive prognostic biomarkers of EOC patients [207,213]. By targeting Four-and-a-half LIM domains protein 2 (FHL2) and Cullin 4A (CUL4A), miR-340 and miR-377 decreased EOC cell migration and invasion, downregulated the $\mathrm{Wnt} / \beta$-catenin pathway, and inhibited EMT $[207,213]$. Furthermore, miR-340-overexpressing EOC cells decreased the volume of ascites and peritoneal metastases in vivo. In addition to FHL2, miR-340 also targets NFKB1 [208]. These findings strongly support a role for miR-340 in inhibiting EOC metastasis. miR-219-5p also inhibited cell proliferation, invasion, and migration, and downregulated the Wnt/ $\beta$-catenin pathway by targeting TWIST1 [202]. Overexpression of miR-219-5p downregulated both TWIST and $\beta$-catenin levels [202], suggesting that decreased expression of TWIST led to the downregulation of $\beta$-catenin via AKT/GSK3 $\beta$ axis [290]. Besides modulating TWIST expression directly, miR-219-5p was reported to target the oncofetal protein, high-mobility group A2 (HMGA2), and reduced subcutaneous tumor growth in vivo [203]. These findings show that these miRNAs have anti-metastatic effects and one of the mechanisms is by downregulating the $\mathrm{Wnt} / \beta$-catenin signaling pathway. Additional studies using in vivo EOC metastasis models are required to further confirm their roles in suppressing EOC metastasis.

Yes-associated protein 1 (YAP1) is a downstream target of the Hippo signaling pathway which promotes the progression of various tumors, including colorectal, bladder, and liver cancers [291-293]. Several miRNAs have been reported to target $Y A P 1$ in EOC. miR-509-3p, which was identified as a positive prognostic predictor in EOC patients, inhibited EOC cell invasion, migration, and spheroid formation by targeting YAP1 [164], suggesting a potential role in inhibiting EOC metastasis. Similarly, miR-375-5p also directly targeted $Y A P 1$ and inhibited EOC cell proliferation, invasion, migration, 
and EMT. Importantly, live animal bioluminescence imaging revealed that inhibition of miR-375-5p resulted in an increase in primary tumor growth and liver and spleen metastases [115], supporting a role for miR-375-5p in repressing EOC metastasis.

Regulation of the Rho pathway by miRNAs modulates cell motility and tumor metastasis [294]. Chen et al. reported that miR-106b, whose expression in EOC tissues was negatively associated with tumor grade and stage, directly targeted RHOC and reduced cell proliferation, invasion, and migration, as well as inhibited tumor growth in vivo [171]. Similarly, Rho-associated coiled-coil-containing protein kinases (ROCKs), including ROCK1 and ROCK2, are targets of miR-148a-3p and miR-139-5p, respectively $[114,188,189]$. Overexpression of miR-148a-3p and miR-139-5p inhibited cell proliferation, invasion, and migration in vitro, as well as suppressed EOC growth in nude mice $[114,188,189]$. On the other hand, miR-138 targets LIMK1, which is activated by signaling through the Rho family GTPases and reported to be a marker for malignant progression in EOC, to inhibit EOC cell proliferation, invasion, and migration [83].

\subsubsection{MicroRNAs Suppress Metastasis by Regulating Adhesion Molecules}

Several miRNAs have been reported to downregulate FAK signaling to inhibit EOC metastasis. miR-708, a significantly downregulated miRNA in highly invasive EOC tissues with advanced stages and metastasis, was shown to inhibit focal adhesion formation, cell invasion, and migration, accompanied by decreased p-FAK and p-Paxillin expression, by targeting Ras family small GTP-binding protein $(R A P 1 B)$ [81]. Overexpression of miR-708 reduced abdominal metastases in the orthotopic metastasis model [81], providing strong evidence that miR-708 suppresses EOC metastasis. In addition, miR-4454 inhibited cell invasion and migration by targeting secreted protein acidic and rich in cysteine (SPARC), a glycoprotein associated with metastatic EOC [295], to inhibit FAK activity. Importantly, when miR-4454-overexpressing EOC cells were inoculated intraperitoneally to the nude mice, fewer peritoneal metastases were observed [232]. These findings indicate that miR-4454 inhibits EOC metastasis and one possible mechanism is to suppress FAK activation.

The integrin $\alpha 5 \beta 1$ pair is a negative prognostic biomarker in EOC patients and participates in cancer cell adherence and mesothelial layer clearance in EOC metastasis [296-298]. miR-17, whose expression was negatively correlated with ITGA5 and ITGB1 expression in various EOC cell lines, decreased cell adhesion and invasion, as well as reduced peritoneal metastatic nodules in vivo by targeting ITGA5 and ITGB1. In addition, miR-17 also repressed ILK phosphorylation and MMP-2 expression [170]. miR-6126, secreted by EOC cells via exosomes, acts on endothelial cells to suppress angiogenesis and on EOC cells to inhibit migration and invasion by directly targeting ITGB1 [234]. Interestingly, miR-6126 delivery via DOPC nanoliposomes into an orthotopic mouse model of ovarian cancer suppressed tumor growth and angiogenesis. Moreover, miR-6126 was found to correlate with better overall survival of EOC patients [234]. These findings strongly support that miR-6126 suppresses metastasis.

\subsubsection{MicroRNAs Suppress Metastasis by Directly Targeting HOX Genes}

Homeobox (HOX) genes encode developmental regulators which are crucial for growth and differentiation. The dysregulation of HOX genes has been observed in various cancers [299]. HOXA10 is overexpressed in EOC and is associated with poor survival [300]. By targeting HOXA10 and CCR2, miR-135a, which is a positive prognostic biomarker in EOC patients, decreased EOC cell proliferation, adhesion, migration, and invasion, reduced Bcl-2 and $\mathrm{N}$-cad expression, as well as increased p53, caspase-3, and E-cadherin expression. Importantly, overexpression of miR-135a reduced subcutaneous tumor growth and lung metastases [182,183], suggesting that miR-135a suppresses metastasis. Similarly, miR-665 also targets HOXA10 and inhibits EOC cell proliferation and migration [229]. On the other hand, miR-612 and miR-202-5p directly target HOXA13 and HOXB2, respectively. Both miRNAs were found to inhibit cell proliferation, invasion, and migration [196,227]. 
In addition, miR-202-5p inhibited EMT in vitro and was identified as a positive prognostic predictor in EOC patients [196].

\subsubsection{MicroRNAs Suppress Metastasis by Directly Targeting HIF}

EOC cells with high levels of hypoxia-inducible factor (HIF) are more likely to disseminate from primary sites to the peritoneal cavity [301]. Moreover, HIF enhances tissue remodeling genes and is associated with EOC patient morbidity and mortality [302]. Joshi et al. reported that HIF transcriptionally suppressed miR-199a-5p in EOC cells, and miR-199a-5p interacted with the $3^{\prime}$ UTR of HIF1A and HIF2A to downregulate their levels, forming a feedback loop [94]. Ectopic miR-199a-5p expression decreased cell migration in vitro and inhibited tumor growth and peritoneal seeding upon intraperitoneal injection of EOC cells in vivo. The down-regulation of HIF also resulted in a decrease in LOX, an ECM remodeling enzyme and a negative prognostic biomarker in EOC patients [94]. LOX has also been reported to promote EOC cell migration and metastasis [95]. These findings provide strong evidence that miR-199a-5p suppresses metastasis, and its indirect regulation of the matrix/tissue remodeling gene expression may be one of the underlying mechanisms.

\section{3. miRNAs that Have Been Reported to Promote and Inhibit Metastasis}

Several miRNAs have been found to exert differential effects on metastasis. For example, the miR-200 family (miR-141/200a/200b/200c/429) has been reported to be either upregulated or downregulated in aggressive EOC and both expression levels were associated with poor survival $[120,126,222,248,249,251,303]$. Several studies have reported tumor-promoting effects of miR-141 in EOC, including enhancing cell proliferation, survival, anoikis resistance, chemoresistance, and peritoneal metastasis [245,304]. Mechanistically, miR-141 has been reported to target KLF12 and SIK1, which are known to exert tumor-suppressive functions, inhibiting anoikis and p53-dependent apoptosis in EOC [245,305]. However, another study found that miR-141 and miR-200a induced tumor growth in a mouse model, but also sensitized tumors to chemotherapeutic drugs by targeting p38 $\alpha$ to regulate oxidative stress [246]. miR-141 [134,247] and miR-200a [134] have also been reported to have inhibitory effects on EOC cell migration and invasion; however, a direct target was not determined in these studies. Similarly, miR-200a was reported to promote cell migration and invasion by targeting PTEN in a HGSC cell line [3], OVCAR3 [248], while impeding vasculogenic mimicry through targeting EPHA2, leading to decreased cell invasion in SKOV3 cells [250], which are thought to represent the EC subtype [3]. Opposing to the association between the upregulation of miR-200a and miR-200b and poor clinical outcomes, miR-200a and miR-200b overexpression reduced IL- 8 and CXCL1 levels and inhibited cell migration, invasion, angiogenesis, and intraperitoneal metastasis in vivo [249]. Interestingly, growing evidence indicates that the miR-200 family may inhibit EMT via direct repression of ZEB1/2 [134,252,306]. Therefore, it has been proposed that the expression of the miR-200 family members is downregulated initially to enhance EMT and increase the invasiveness of EOC cells, and is then upregulated to induce mesenchymal-to-epithelial-transition (MET) and achieve re-epithelialization of tumor cells in distant metastatic sites [307]. It has been suggested that the downregulation of miR-200s occurs during the progression of tumor cells gaining metastatic capability [308]. Furthermore, metastatic EOC tissues showed increased MET markers when compared to primary cancer tissues [309], suggesting a possible downregulation of the miR-200 family at some point during the re-epithelialization process. Whether or not the miR-200 family has subtype- and/or stage-specific effects on metastasis requires further investigation.

In addition to the miR-200 family, other studies reported that in the SKOV3 cell line, miR-9 either increased migration and invasion by targeting $C D H 1$ or inhibited migration and invasion by targeting TLN1 [242,244]. These studies also examined miR-9 expression in tissue samples, but observed a higher expression in serous EOC metastases compared to primary tumors [242] and lower expression in recurrent serous EOC tumors compared to primary EOC tissues [243]. The opposing effects of miR-9 also have been reported in other cancers, with varied targets and functional roles which are 
more likely dependent on tissue or cell type [310-312]. Similarly, miR-203 promoted OVCA429 and OVCA433 cell proliferation and migration in vitro, as well as tumor metastasis in vivo, by targeting pyruvate dehydrogenase $\mathrm{B}(\mathrm{PDHB})$ and the subsequent enhancement of glycolysis [118]. In contrast, ectopic miR-203 expression in SKOV3 and OVCAR3 cells attenuated EMT, cell migration, and invasion in vitro and tumor growth in vivo, by targeting SNAI2 [118] and BIRC5 [254]. The reasons for such discrepancies are not clear; however, the relative levels of different target genes and their functions in tumor development may contribute to the differential effects of miRNAs.

\section{Conclusions and Future Direction}

Cancer metastasis is one of the main factors that leads to poor clinical outcomes for EOC patients. Accumulating evidence demonstrates that miRNAs play important roles in EOC metastasis. Aberrant expression of miRNAs has been reported in EOC. Such dysregulation can be attributed to alterations at the DNA level, such as amplification and hypermethylation at the promoter regions of miRNA genes. In addition, altered transcriptional controls and defects in miRNA biogenesis machinery also contribute to the abnormality of miRNA levels. Many studies have reported that miRNA expression profiles correlate with clinical features, such as tumor stage, grade, and overall survival of patients, raising the possibility of using miRNAs as diagnostic and/or prognostic markers.

Due to the heterogeneity of EOC, it is a challenge to find effective biomarkers for detecting EOC in different tumors [313]. miRNA profiling studies have sometimes reported inconsistent findings. One of the underlying issues could be the controls used. Some researchers used normal ovarian tissues as the control while others used benign tumors. Methylation patterns of some miRNA genes have been shown to be correlated with metastasis [116,257]. In addition, miRNAs are detected in biological fluids, which can serve as a non-invasive tool for EOC diagnosis. Further efforts in validating the specificity and sensitivity of miRNA signatures in a large cohort of EOC patients are needed for the development of miRNAs as diagnostic and prognostic biomarkers.

Metastasis of ovarian cancer is orchestrated by several interconnected biological processes, including EMT, increase in cell mobility and migration, destruction of the ECM, formation of spheroids, avoidance of apoptosis, angiogenesis, and immune suppression [91]. Some miRNAs have been reported to promote metastasis, mainly by targeting negative regulators of these processes. On the other hand, most miRNAs that have been studied exert suppressive effects on metastasis, mainly by inhibiting transcription factors that induce the expression of mesenchymal markers, or key signaling pathways that promote EMT, motility, and tumor angiogenesis. Therefore, the upregulation of metastasis-promoting miRNAs and downregulation of metastasis-suppressing miRNAs would lead to a dysregulated signaling network and promote metastasis. However, more work is required to better understand the role of miRNAs and the underlying mechanisms by which they regulate metastasis. Among the studies reported so far, some are comprehensive, but most only examined the effects of miRNAs using established EOC cell lines in vitro. Therefore, further in vivo experiments would verify the roles of those miRNAs in metastasis of EOC. Moreover, miRNAs can target many genes and it is possible that they could exert tumor-promoting or tumor-suppressive effects, depending on the relative abundance and/or functions of target genes in different tumor contexts. Most studies have been focused on one or a few target genes. Additional studies in identifying critical targets that are directly involved in the induction of EOC metastasis would enhance our understanding of the roles of miRNAs in these processes. Finally, EOC consists of multiple histological subtypes, each one with unique origins and distinct molecular features [3]. More work on examining the dysregulation and functions of miRNAs in different subtypes of EOC is warranted as it may help to develop precise therapeutics. miRNAs have been suggested as promising therapeutic targets for cancer treatment [314]. miRNA-based therapies have been established for lung cancer treatment and further trials are anticipated to address clinical treatment efficacy [314]. It is possible that the restoration of down-regulated miRNAs that inhibit metastasis or inhibition of up-regulated miRNAs that promote metastasis could be used in the future as a therapeutic approach for EOC. 
Funding: Studies performed in our lab were supported by grants from Canadian Institutes of Health (MOP-89931, PJT-153146, and PJT-419466), Canada Foundation of Innovation (CFI-356111), and the York Research Chair Program to C.P. J.O. received a graduate scholarship from Natural Science and Engineering Canada (NSERC). C.Y. and K.D. were supported by an NSERC undergraduate student research award with supplemental funding from the Faculty of Science, York University.

Conflicts of Interest: The authors declare no conflict of interest.

\section{References}

1. Siegel, R.L.; Miller, K.D.; Jemal, A. Cancer statistics, 2019. CA Cancer J. Clin. 2019, 69, 7-34. [CrossRef] [PubMed]

2. Boussios, S.; Moschetta, M.; Zarkavelis, G.; Papadaki, A.; Kefas, A.; Tatsi, K. Ovarian sex-cord stromal tumours and small cell tumours: Pathological, genetic and management aspects. Crit. Rev. Oncol. Hematol. 2017, 120, 43-51. [CrossRef] [PubMed]

3. National Academies of Sciences, Engineering, and Medicine. Ovarian Cancers: Evolving Paradigms in Research and Care; The National Academies Press: Washington, DC, USA, 2016; p. 396. [CrossRef]

4. Lupia, M.; Cavallaro, U. Ovarian cancer stem cells: Still an elusive entity? Mol. Cancer 2017, 16, 64. [CrossRef]

5. Webb, P.M.; Jordan, S.J. Epidemiology of epithelial ovarian cancer. Best Pract. Res. Clin. Obstet. Gynaecol. 2017, 41, 3-14. [CrossRef]

6. Matulonis, U.A.; Sood, A.K.; Fallowfield, L.; Howitt, B.E.; Sehouli, J.; Karlan, B.Y. Ovarian cancer. Nat. Rev. Dis. Primers 2016, 2, 16061. [CrossRef] [PubMed]

7. Lagos-Quintana, M.; Rauhut, R.; Lendeckel, W.; Tuschl, T. Identification of novel genes coding for small expressed RNAs. Science 2001, 294, 853-858. [CrossRef]

8. Ambros, V. microRNAs: Tiny regulators with great potential. Cell 2001, 107, 823-826. [CrossRef]

9. Friedman, R.C.; Farh, K.K.; Burge, C.B.; Bartel, D.P. Most mammalian mRNAs are conserved targets of microRNAs. Genome Res. 2009, 19, 92-105. [CrossRef]

10. Vidigal, J.A.; Ventura, A. The biological functions of miRNAs: Lessons from in vivo studies. Trends Cell Biol. 2015, 25, 137-147. [CrossRef]

11. Staicu, C.E.; Predescu, D.V.; Rusu, C.M.; Radu, B.M.; Cretoiu, D.; Suciu, N.; Cretoiu, S.M.; Voinea, S.C. Role of microRNAs as Clinical Cancer Biomarkers for Ovarian Cancer: A Short Overview. Cells 2020, 9, 169. [CrossRef]

12. Chen, S.N.; Chang, R.; Lin, L.T.; Chern, C.U.; Tsai, H.W.; Wen, Z.H.; Li, Y.H.; Li, C.J.; Tsui, K.H. MicroRNA in Ovarian Cancer: Biology, Pathogenesis, and Therapeutic Opportunities. Int. J. Environ. Res. Public Health 2019, 16, 1510. [CrossRef] [PubMed]

13. Roberts, C.M.; Cardenas, C.; Tedja, R. The Role of Intra-Tumoral Heterogeneity and Its Clinical Relevance in Epithelial Ovarian Cancer Recurrence and Metastasis. Cancers 2019, 11, 1083. [CrossRef]

14. Godnic, I.; Zorc, M.; Jevsinek Skok, D.; Calin, G.A.; Horvat, S.; Dovc, P.; Kovac, M.; Kunej, T. Genome-wide and species-wide in silico screening for intragenic MicroRNAs in human, mouse and chicken. PLoS ONE 2013, 8, e65165. [CrossRef] [PubMed]

15. de Rie, D.; Abugessaisa, I.; Alam, T.; Arner, E.; Arner, P.; Ashoor, H.; Astrom, G.; Babina, M.; Bertin, N.; Burroughs, A.M.; et al. An integrated expression atlas of miRNAs and their promoters in human and mouse. Nat. Biotechnol. 2017, 35, 872-878. [CrossRef]

16. Kim, Y.K.; Kim, V.N. Processing of intronic microRNAs. EMBO J. 2007, 26, 775-783. [CrossRef]

17. Ramalingam, P.; Palanichamy, J.K.; Singh, A.; Das, P.; Bhagat, M.; Kassab, M.A.; Sinha, S.; Chattopadhyay, P. Biogenesis of intronic miRNAs located in clusters by independent transcription and alternative splicing. RNA 2014, 20, 76-87. [CrossRef]

18. Kirigin, F.F.; Lindstedt, K.; Sellars, M.; Ciofani, M.; Low, S.L.; Jones, L.; Bell, F.; Pauli, F.; Bonneau, R.; Myers, R.M.; et al. Dynamic microRNA gene transcription and processing during T cell development. J. Immunol. 2012, 188, 3257-3267. [CrossRef]

19. Lee, Y.; Kim, M.; Han, J.; Yeom, K.H.; Lee, S.; Baek, S.H.; Kim, V.N. MicroRNA genes are transcribed by RNA polymerase II. EMBO J. 2004, 23, 4051-4060. [CrossRef]

20. Kim, Y.K.; Kim, B.; Kim, V.N. Re-evaluation of the roles of DROSHA, Export in 5, and DICER in microRNA biogenesis. Proc. Natl. Acad. Sci. USA 2016, 113, E1881-E1889. [CrossRef] 
21. Gregory, R.I.; Yan, K.P.; Amuthan, G.; Chendrimada, T.; Doratotaj, B.; Cooch, N.; Shiekhattar, R. The Microprocessor complex mediates the genesis of microRNAs. Nature 2004, 432, 235-240. [CrossRef] [PubMed]

22. Triboulet, R.; Chang, H.M.; Lapierre, R.J.; Gregory, R.I. Post-transcriptional control of DGCR8 expression by the Microprocessor. RNA 2009, 15, 1005-1011. [CrossRef] [PubMed]

23. Bohnsack, M.T.; Czaplinski, K.; Gorlich, D. Exportin 5 is a RanGTP-dependent dsRNA-binding protein that mediates nuclear export of pre-miRNAs. RNA 2004, 10, 185-191. [CrossRef] [PubMed]

24. Lund, E.; Dahlberg, J.E. Substrate selectivity of exportin 5 and Dicer in the biogenesis of microRNAs. Cold Spring Harb. Symp. Quant. Biol. 2006, 71, 59-66. [CrossRef] [PubMed]

25. Ruby, J.G.; Jan, C.H.; Bartel, D.P. Intronic microRNA precursors that bypass Drosha processing. Nature 2007, 448, 83-86. [CrossRef] [PubMed]

26. Babiarz, J.E.; Ruby, J.G.; Wang, Y.; Bartel, D.P.; Blelloch, R. Mouse ES cells express endogenous shRNAs, siRNAs, and other Microprocessor-independent, Dicer-dependent small RNAs. Genes Dev. 2008, 22, 2773-2785. [CrossRef] [PubMed]

27. Grishok, A.; Pasquinelli, A.E.; Conte, D.; Li, N.; Parrish, S.; Ha, I.; Baillie, D.L.; Fire, A.; Ruvkun, G.; Mello, C.C. Genes and mechanisms related to RNA interference regulate expression of the small temporal RNAs that control C. elegans developmental timing. Cell 2001, 106, 23-34. [CrossRef]

28. Bernstein, E.; Caudy, A.A.; Hammond, S.M.; Hannon, G.J. Role for a bidentate ribonuclease in the initiation step of RNA interference. Nature 2001, 409, 363-366. [CrossRef]

29. Knight, S.W.; Bass, B.L. A role for the RNase III enzyme DCR-1 in RNA interference and germ line development in Caenorhabditis elegans. Science 2001, 293, 2269-2271. [CrossRef]

30. Hammond, S.M.; Bernstein, E.; Beach, D.; Hannon, G.J. An RNA-directed nuclease mediates post-transcriptional gene silencing in Drosophila cells. Nature 2000, 404, 293-296. [CrossRef]

31. Gregory, R.I.; Chendrimada, T.P.; Cooch, N.; Shiekhattar, R. Human RISC couples microRNA biogenesis and posttranscriptional gene silencing. Cell 2005, 123, 631-640. [CrossRef]

32. Yoda, M.; Kawamata, T.; Paroo, Z.; Ye, X.; Iwasaki, S.; Liu, Q.; Tomari, Y. ATP-dependent human RISC assembly pathways. Nat. Struct. Mol. Biol. 2010, 17, 17-23. [CrossRef] [PubMed]

33. Hammond, S.M.; Boettcher, S.; Caudy, A.A.; Kobayashi, R.; Hannon, G.J. Argonaute2, a link between genetic and biochemical analyses of RNAi. Science 2001, 293, 1146-1150. [CrossRef] [PubMed]

34. Kawamata, T.; Tomari, Y. Making RISC. Trends Biochem. Sci. 2010, 35, 368-376. [CrossRef]

35. Su, H.; Trombly, M.I.; Chen, J.; Wang, X. Essential and overlapping functions for mammalian Argonautes in microRNA silencing. Genes Dev. 2009, 23, 304-317. [CrossRef] [PubMed]

36. Kadekar, S.; Nawale, G.N.; Karlsson, K.; Alander, C.; Oommen, O.P.; Varghese, O.P. Synthetic Design of Asymmetric miRNA with an Engineered 3' Overhang to Improve Strand Selection. Mol. Ther. Nucleic Acids 2019, 16, 597-604. [CrossRef]

37. Meister, G.; Landthaler, M.; Patkaniowska, A.; Dorsett, Y.; Teng, G.; Tuschl, T. Human Argonaute2 mediates RNA cleavage targeted by miRNAs and siRNAs. Mol. Cell. 2004, 15, 185-197. [CrossRef]

38. O'Brien, J.; Hayder, H.; Zayed, Y.; Peng, C. Overview of MicroRNA Biogenesis, Mechanisms of Actions, and Circulation. Front. Endocrinol. (Lausanne) 2018, 9, 402. [CrossRef]

39. Huntzinger, E.; Izaurralde, E. Gene silencing by microRNAs: Contributions of translational repression and mRNA decay. Nat. Rev. Genet. 2011, 12,99-110. [CrossRef]

40. Pfaff, J.; Meister, G. Argonaute and GW182 proteins: An effective alliance in gene silencing. Biochem. Soc. Trans. 2013, 41, 855-860. [CrossRef]

41. Christie, M.; Boland, A.; Huntzinger, E.; Weichenrieder, O.; Izaurralde, E. Structure of the PAN3 pseudokinase reveals the basis for interactions with the PAN2 deadenylase and the GW182 proteins. Mol. Cell 2013, 51, 360-373. [CrossRef]

42. Jonas, S.; Izaurralde, E. Towards a molecular understanding of microRNA-mediated gene silencing. Nat. Rev. Genet. 2015, 16, 421-433. [CrossRef] [PubMed]

43. Behm-Ansmant, I.; Rehwinkel, J.; Doerks, T.; Stark, A.; Bork, P.; Izaurralde, E. mRNA degradation by miRNAs and GW182 requires both CCR4:NOT deadenylase and DCP1:DCP2 decapping complexes. Genes Dev. 2006, 20, 1885-1898. [CrossRef] [PubMed] 
44. Braun, J.E.; Truffault, V.; Boland, A.; Huntzinger, E.; Chang, C.T.; Haas, G.; Weichenrieder, O.; Coles, M.; Izaurralde, E. A direct interaction between DCP1 and XRN1 couples mRNA decapping to 5' exonucleolytic degradation. Nat. Struct. Mol. Biol. 2012, 19, 1324-1331. [CrossRef] [PubMed]

45. Wilczynska, A.; Bushell, M. The complexity of miRNA-mediated repression. Cell Death Differ. 2015, 22, 22-33. [CrossRef] [PubMed]

46. Xu, W.; San Lucas, A.; Wang, Z.; Liu, Y. Identifying microRNA targets in different gene regions. BMC Bioinform. 2014, 15 (Suppl. 7), S4. [CrossRef] [PubMed]

47. Dharap, A.; Pokrzywa, C.; Murali, S.; Pandi, G.; Vemuganti, R. MicroRNA miR-324-3p induces promoter-mediated expression of RelA gene. PLoS ONE 2013, 8, e79467. [CrossRef]

48. Forman, J.J.; Legesse-Miller, A.; Coller, H.A. A search for conserved sequences in coding regions reveals that the let-7 microRNA targets Dicer within its coding sequence. Proc. Natl. Acad. Sci. USA 2008, 105, 14879-14884. [CrossRef]

49. Zhang, J.; Zhou, W.; Liu, Y.; Liu, T.; Li, C.; Wang, L. Oncogenic role of microRNA-532-5p in human colorectal cancer via targeting of the 5'UTR of RUNX3. Oncol. Lett. 2018, 15, 7215-7220. [CrossRef]

50. Truesdell, S.S.; Mortensen, R.D.; Seo, M.; Schroeder, J.C.; Lee, J.H.; LeTonqueze, O.; Vasudevan, S. MicroRNA-mediated mRNA translation activation in quiescent cells and oocytes involves recruitment of a nuclear microRNP. Sci. Rep. 2012, 2, 842. [CrossRef]

51. Orom, U.A.; Nielsen, F.C.; Lund, A.H. MicroRNA-10a binds the 5'UTR of ribosomal protein mRNAs and enhances their translation. Mol. Cell. 2008, 30, 460-471. [CrossRef]

52. Tan, D.S.; Agarwal, R.; Kaye, S.B. Mechanisms of transcoelomic metastasis in ovarian cancer. Lancet Oncol. 2006, 7, 925-934. [CrossRef]

53. Yeung, T.L.; Leung, C.S.; Yip, K.P.; Au Yeung, C.L.; Wong, S.T.; Mok, S.C. Cellular and molecular processes in ovarian cancer metastasis. A Review in the Theme: Cell and Molecular Processes in Cancer Metastasis. Am. J. Physiol. Cell Physiol. 2015, 309, C444-C456. [CrossRef] [PubMed]

54. Lengyel, E. Ovarian cancer development and metastasis. Am. J. Pathol. 2010, 177, 1053-1064. [CrossRef] [PubMed]

55. Micalizzi, D.S.; Farabaugh, S.M.; Ford, H.L. Epithelial-mesenchymal transition in cancer: Parallels between normal development and tumor progression. J. Mammary Gland Biol. Neoplasia 2010, 15, 117-134. [CrossRef] [PubMed]

56. Onder, T.T.; Gupta, P.B.; Mani, S.A.; Yang, J.; Lander, E.S.; Weinberg, R.A. Loss of E-cadherin promotes metastasis via multiple downstream transcriptional pathways. Cancer Res. 2008, 68, 3645-3654. [CrossRef]

57. Mani, S.A.; Yang, J.; Brooks, M.; Schwaninger, G.; Zhou, A.; Miura, N.; Kutok, J.L.; Hartwell, K.; Richardson, A.L.; Weinberg, R.A. Mesenchyme Forkhead 1 (FOXC2) plays a key role in metastasis and is associated with aggressive basal-like breast cancers. Proc. Natl. Acad. Sci. USA 2007, 104, 10069-10074. [CrossRef]

58. Davidson, B.; Trope, C.G.; Reich, R. Epithelial-mesenchymal transition in ovarian carcinoma. Front. Oncol. 2012, 2, 33. [CrossRef]

59. Palma Flores, C.; Garcia-Vazquez, R.; Gallardo Rincon, D.; Ruiz-Garcia, E.; Astudillo de la Vega, H.; Marchat, L.A.; Salinas Vera, Y.M.; Lopez-Camarillo, C. MicroRNAs driving invasion and metastasis in ovarian cancer: Opportunities for translational medicine (Review). Int. J. Oncol. 2017, 50, 1461-1476. [CrossRef]

60. Peinado, H.; Olmeda, D.; Cano, A. Snail, Zeb and bHLH factors in tumour progression: An alliance against the epithelial phenotype? Nat. Rev. Cancer 2007, 7, 415-428. [CrossRef]

61. Yang, J.; Weinberg, R.A. Epithelial-mesenchymal transition: At the crossroads of development and tumor metastasis. Dev. Cell 2008, 14, 818-829. [CrossRef]

62. Tsai, J.H.; Yang, J. Epithelial-mesenchymal plasticity in carcinoma metastasis. Genes Dev. 2013, 27, $2192-2206$. [CrossRef] [PubMed]

63. Sun, Y.; Hu, L.; Zheng, H.; Bagnoli, M.; Guo, Y.; Rupaimoole, R.; Rodriguez-Aguayo, C.; Lopez-Berestein, G.; Ji, P.; Chen, K.; et al. MiR-506 inhibits multiple targets in the epithelial-to-mesenchymal transition network and is associated with good prognosis in epithelial ovarian cancer. J. Pathol. 2015, 235, 25-36. [CrossRef] [PubMed]

64. Kalluri, R.; Weinberg, R.A. The basics of epithelial-mesenchymal transition. J. Clin. Investig. 2009, 119, 1420-1428. [CrossRef] [PubMed] 
65. Nusse, R.; Clevers, H. Wnt/beta-Catenin Signaling, Disease, and Emerging Therapeutic Modalities. Cell 2017, 169, 985-999. [CrossRef] [PubMed]

66. Nguyen, V.H.L.; Hough, R.; Bernaudo, S.; Peng, C. Wnt/beta-catenin signalling in ovarian cancer: Insights into its hyperactivation and function in tumorigenesis. J. Ovarian Res. 2019, 12, 122. [CrossRef]

67. Rafehi, S.; Ramos Valdes, Y.; Bertrand, M.; McGee, J.; Prefontaine, M.; Sugimoto, A.; DiMattia, G.E.; Shepherd, T.G. TGFbeta signaling regulates epithelial-mesenchymal plasticity in ovarian cancer ascites-derived spheroids. Endocr. Relat. Cancer 2016, 23, 147-159. [CrossRef]

68. Zhou, X.; Hu, Y.; Dai, L.; Wang, Y.; Zhou, J.; Wang, W.; Di, W.; Qiu, L. MicroRNA-7 inhibits tumor metastasis and reverses epithelial-mesenchymal transition through AKT/ERK1/2 inactivation by targeting EGFR in epithelial ovarian cancer. PLoS ONE 2014, 9, e96718. [CrossRef]

69. Moran-Jones, K. The Therapeutic Potential of Targeting the HGF/cMET Axis in Ovarian Cancer. Mol. Diagn. Ther. 2016, 20, 199-212. [CrossRef]

70. Zhang, R.; Shi, H.; Ren, F.; Feng, W.; Cao, Y.; Li, G.; Liu, Z.; Ji, P.; Zhang, M. MicroRNA-338-3p suppresses ovarian cancer cells growth and metastasis: Implication of Wnt/catenin beta and MEK/ERK signaling pathways. J. Exp. Clin. Cancer Res. CR 2019, 38, 494. [CrossRef]

71. Zhang, Y.; Xia, M.; Jin, K.; Wang, S.; Wei, H.; Fan, C.; Wu, Y.; Li, X.; Li, X.; Li, G.; et al. Function of the c-Met receptor tyrosine kinase in carcinogenesis and associated therapeutic opportunities. Mol. Cancer 2018, $17,45$. [CrossRef]

72. Ke, Z.; Caiping, S.; Qing, Z.; Xiaojing, W. Sonic hedgehog-Gli1 signals promote epithelial-mesenchymal transition in ovarian cancer by mediating PI3K/AKT pathway. Med. Oncol. (Northwood Lond. Engl.) 2015, 32, 368. [CrossRef] [PubMed]

73. Do, T.V.; Xiao, F.; Bickel, L.E.; Klein-Szanto, A.J.; Pathak, H.B.; Hua, X.; Howe, C.; O’Brien, S.W.; Maglaty, M.; Ecsedy, J.A.; et al. Aurora kinase A mediates epithelial ovarian cancer cell migration and adhesion. Oncogene 2014, 33, 539-549. [CrossRef] [PubMed]

74. Boussios, S.; Mikropoulos, C.; Samartzis, E.; Karihtala, P.; Moschetta, M.; Sheriff, M.; Karathanasi, A.; Sadauskaite, A.; Rassy, E.; Pavlidis, N. Wise Management of Ovarian Cancer: On the Cutting Edge. J. Pers. Med. 2020, 10, 41. [CrossRef] [PubMed]

75. Mitra, S.K.; Hanson, D.A.; Schlaepfer, D.D. Focal adhesion kinase: In command and control of cell motility. Nat. Rev. Mol. Cell Biol. 2005, 6, 56-68. [CrossRef]

76. Cance, W.G.; Golubovskaya, V.M. Focal adhesion kinase versus p53: Apoptosis or survival? Sci. Signal. 2008, 1, pe22. [CrossRef]

77. Frisch, S.M.; Schaller, M.; Cieply, B. Mechanisms that link the oncogenic epithelial-mesenchymal transition to suppression of anoikis. J. Cell Sci. 2013, 126, 21-29. [CrossRef]

78. Shibue, T.; Brooks, M.W.; Inan, M.F.; Reinhardt, F.; Weinberg, R.A. The outgrowth of micrometastases is enabled by the formation of filopodium-like protrusions. Cancer Discov. 2012, 2, 706-721. [CrossRef]

79. Sood, A.K.; Coffin, J.E.; Schneider, G.B.; Fletcher, M.S.; DeYoung, B.R.; Gruman, L.M.; Gershenson, D.M.; Schaller, M.D.; Hendrix, M.J. Biological significance of focal adhesion kinase in ovarian cancer: Role in migration and invasion. Am. J. Pathol. 2004, 165, 1087-1095. [CrossRef]

80. Zhao, J.; Guan, J.L. Signal transduction by focal adhesion kinase in cancer. Cancer Metastasis Rev. 2009, 28, 35-49. [CrossRef]

81. Lin, K.T.; Yeh, Y.M.; Chuang, C.M.; Yang, S.Y.; Chang, J.W.; Sun, S.P.; Wang, Y.S.; Chao, K.C.; Wang, L.H. Glucocorticoids mediate induction of microRNA-708 to suppress ovarian cancer metastasis through targeting Rap1B. Nat. Commun. 2015, 6, 5917. [CrossRef]

82. Mei, J.; Huang, Y.; Hao, L.; Liu, Y.; Yan, T.; Qiu, T.; Xu, R.; Xu, B.; Xiao, Z.; Jiang, X.; et al. DAAM1-mediated migration and invasion of ovarian cancer cells are suppressed by miR-208a-5p. Pathol. Res. Pract. 2019, 215, 152452. [CrossRef] [PubMed]

83. Chen, P.; Zeng, M.; Zhao, Y.; Fang, X. Upregulation of Limk1 caused by microRNA-138 loss aggravates the metastasis of ovarian cancer by activation of Limk1/cofilin signaling. Oncol. Rep. 2014, 32, 2070-2076. [CrossRef] [PubMed]

84. Prunier, C.; Prudent, R.; Kapur, R.; Sadoul, K.; Lafanechere, L. LIM kinases: Cofilin and beyond. Oncotarget 2017, 8, 41749-41763. [CrossRef] [PubMed] 
85. Wang, L.; Mezencev, R.; Svajdler, M.; Benigno, B.B.; McDonald, J.F. Ectopic over-expression of miR-429 induces mesenchymal-to-epithelial transition (MET) and increased drug sensitivity in metastasizing ovarian cancer cells. Gynecol. Oncol. 2014, 134, 96-103. [CrossRef] [PubMed]

86. Luo, X.; Dong, Z.; Chen, Y.; Yang, L.; Lai, D. Enrichment of ovarian cancer stem-like cells is associated with epithelial to mesenchymal transition through an miRNA-activated AKT pathway. Cell Prolif. 2013, 46, 436-446. [CrossRef]

87. Persad, S.; Dedhar, S. The role of integrin-linked kinase (ILK) in cancer progression. Cancer Metastasis Rev. 2003, 22, 375-384. [CrossRef]

88. Scheau, C.; Badarau, I.A.; Costache, R.; Caruntu, C.; Mihai, G.L.; Didilescu, A.C.; Constantin, C.; Neagu, M. The Role of Matrix Metalloproteinases in the Epithelial-Mesenchymal Transition of Hepatocellular Carcinoma. Anal. Cell Pathol. (Amst.) 2019, 2019, 9423907. [CrossRef]

89. Jin, H.; Yu, Y.; Zhang, T.; Zhou, X.; Zhou, J.; Jia, L.; Wu, Y.; Zhou, B.P.; Feng, Y. Snail is critical for tumor growth and metastasis of ovarian carcinoma. Int. J. Cancer 2010, 126, 2102-2111. [CrossRef]

90. Paoli, P.; Giannoni, E.; Chiarugi, P. Anoikis molecular pathways and its role in cancer progression. Biochim. Biophys. Acta 2013, 1833, 3481-3498. [CrossRef]

91. Braga, E.A.; Fridman, M.V.; Kushlinskii, N.E. Molecular Mechanisms of Ovarian Carcinoma Metastasis: Key Genes and Regulatory MicroRNAs. Biochemistry 2017, 82, 529-541. [CrossRef]

92. Semenza, G.L. Hypoxia-inducible factors: Mediators of cancer progression and targets for cancer therapy. Trends Pharmacol. Sci. 2012, 33, 207-214. [CrossRef] [PubMed]

93. Keith, B.; Johnson, R.S.; Simon, M.C. HIF1alpha and HIF2alpha: Sibling rivalry in hypoxic tumour growth and progression. Nat. Rev. Cancer 2011, 12, 9-22. [CrossRef] [PubMed]

94. Joshi, H.P.; Subramanian, I.V.; Schnettler, E.K.; Ghosh, G.; Rupaimoole, R.; Evans, C.; Saluja, M.; Jing, Y.; Cristina, I.; Roy, S.; et al. Dynamin 2 along with microRNA-199a reciprocally regulate hypoxia-inducible factors and ovarian cancer metastasis. Proc. Natl. Acad. Sci. USA 2014, 111, 5331-5336. [CrossRef] [PubMed]

95. Schietke, R.; Warnecke, C.; Wacker, I.; Schodel, J.; Mole, D.R.; Campean, V.; Amann, K.; Goppelt-Struebe, M.; Behrens, J.; Eckardt, K.U.; et al. The lysyl oxidases LOX and LOXL2 are necessary and sufficient to repress E-cadherin in hypoxia: Insights into cellular transformation processes mediated by HIF-1. J. Biol. Chem. 2010, 285, 6658-6669. [CrossRef]

96. Bindra, R.S.; Gibson, S.L.; Meng, A.; Westermark, U.; Jasin, M.; Pierce, A.J.; Bristow, R.G.; Classon, M.K.; Glazer, P.M. Hypoxia-induced down-regulation of BRCA1 expression by E2Fs. Cancer Res. 2005, 65, 11597-11604. [CrossRef]

97. Boussios, S.; Karihtala, P.; Moschetta, M.; Karathanasi, A.; Sadauskaite, A.; Rassy, E.; Pavlidis, N. Combined Strategies with Poly (ADP-Ribose) Polymerase (PARP) Inhibitors for the Treatment of Ovarian Cancer: A Literature Review. Diagnostics 2019, 9, 87. [CrossRef]

98. Balkwill, F. Cancer and the chemokine network. Nat. Rev. Cancer 2004, 4, 540-550. [CrossRef]

99. Lv, Y.; Lei, Y.; Hu, Y.; Ding, W.; Zhang, C.; Fang, C. miR-448 negatively regulates ovarian cancer cell growth and metastasis by targeting CXCL12. Clin. Transl. Oncol. 2015, 17, 903-909. [CrossRef]

100. Casey, R.C.; Skubitz, A.P. CD44 and beta1 integrins mediate ovarian carcinoma cell migration toward extracellular matrix proteins. Clin. Exp. Metastasis 2000, 18, 67-75. [CrossRef]

101. Santoiemma, P.P.; Powell, D.J., Jr. Tumor infiltrating lymphocytes in ovarian cancer. Cancer Biol. Ther. 2015, 16, 807-820. [CrossRef]

102. Zhou, J.; Li, X.; Wu, X.; Zhang, T.; Zhu, Q.; Wang, X.; Wang, H.; Wang, K.; Lin, Y.; Wang, X. Exosomes Released from Tumor-Associated Macrophages Transfer miRNAs That Induce a Treg/Th17 Cell Imbalance in Epithelial Ovarian Cancer. Cancer Immunol. Res. 2018, 6, 1578-1592. [CrossRef] [PubMed]

103. Wang, X.; Zhu, Q.; Lin, Y.; Wu, L.; Wu, X.; Wang, K.; He, Q.; Xu, C.; Wan, X.; Wang, X. Crosstalk between TEMs and endothelial cells modulates angiogenesis and metastasis via IGF1-IGF1R signalling in epithelial ovarian cancer. Br. J. Cancer 2017, 117, 1371-1382. [CrossRef] [PubMed]

104. Mantovani, A.; Sozzani, S.; Locati, M.; Allavena, P.; Sica, A. Macrophage polarization: Tumor-associated macrophages as a paradigm for polarized M2 mononuclear phagocytes. Trends. Immunol. 2002, 23, 549-555. [CrossRef]

105. Jiang, B.; Zhu, S.J.; Xiao, S.S.; Xue, M. MiR-217 Inhibits M2-Like Macrophage Polarization by Suppressing Secretion of Interleukin-6 in Ovarian Cancer. Inflammation 2019, 42, 1517-1529. [CrossRef] 
106. Xie, J.; Liu, M.; Li, Y.; Nie, Y.; Mi, Q.; Zhao, S. Ovarian tumor-associated microRNA-20a decreases natural killer cell cytotoxicity by downregulating MICA/B expression. Cell Mol. Immunol. 2014, 11, 495-502. [CrossRef]

107. Ghadially, H.; Brown, L.; Lloyd, C.; Lewis, L.; Lewis, A.; Dillon, J.; Sainson, R.; Jovanovic, J.; Tigue, N.J.; Bannister, D.; et al. MHC class I chain-related protein A and B (MICA and MICB) are predominantly expressed intracellularly in tumour and normal tissue. Br. J. Cancer 2017, 116, 1208-1217. [CrossRef]

108. Nam, J.W.; Rissland, O.S.; Koppstein, D.; Abreu-Goodger, C.; Jan, C.H.; Agarwal, V.; Yildirim, M.A.; Rodriguez, A.; Bartel, D.P. Global analyses of the effect of different cellular contexts on microRNA targeting. Mol. Cell 2014, 53, 1031-1043. [CrossRef]

109. He, M.; Liu, Y.; Wang, X.; Zhang, M.Q.; Hannon, G.J.; Huang, Z.J. Cell-type-based analysis of microRNA profiles in the mouse brain. Neuron 2012, 73, 35-48. [CrossRef]

110. Parikh, A.; Lee, C.; Joseph, P.; Marchini, S.; Baccarini, A.; Kolev, V.; Romualdi, C.; Fruscio, R.; Shah, H.; Wang, F.; et al. microRNA-181a has a critical role in ovarian cancer progression through the regulation of the epithelial-mesenchymal transition. Nat. Commun. 2014, 5, 2977. [CrossRef]

111. Chen, Z.; Zhu, J.; Zhu, Y.; Wang, J. MicroRNA-616 promotes the progression of ovarian cancer by targeting TIMP2. Oncol. Rep. 2018, 39, 2960-2968. [CrossRef]

112. Salem, M.; O’Brien, J.A.; Bernaudo, S.; Shawer, H.; Ye, G.; Brkic, J.; Amleh, A.; Vanderhyden, B.C.; Refky, B.; Yang, B.B.; et al. miR-590-3p Promotes Ovarian Cancer Growth and Metastasis via a Novel FOXA2-Versican Pathway. Cancer Res. 2018, 78, 4175-4190. [CrossRef] [PubMed]

113. Ying, X.; Wei, K.; Lin, Z.; Cui, Y.; Ding, J.; Chen, Y.; Xu, B. MicroRNA-125b Suppresses Ovarian Cancer Progression via Suppression of the Epithelial-Mesenchymal Transition Pathway by Targeting the SET Protein. Cell. Physiol. Biochem. Int. J. Exp. Cell. Physiol. Biochem. Pharmacol. 2016, 39, 501-510. [CrossRef] [PubMed]

114. Pan, L.; Meng, Q.; Li, H.; Liang, K.; Li, B. LINC00339 promotes cell proliferation, migration, and invasion of ovarian cancer cells via miR-148a-3p/ROCK1 axes. Biomed. Pharmacother. 2019, 120, 109423. [CrossRef]

115. Yan, H.; Li, H.; Li, P.; Li, X.; Lin, J.; Zhu, L.; Silva, M.A.; Wang, X.; Wang, P.; Zhang, Z. Long noncoding RNA MLK7-AS1 promotes ovarian cancer cells progression by modulating miR-375/YAP1 axis. J. Exp. Clin. Cancer Res. CR 2018, 37, 237. [CrossRef] [PubMed]

116. Loginov, V.I.; Pronina, I.V.; Burdennyy, A.M.; Filippova, E.A.; Kazubskaya, T.P.; Kushlinsky, D.N.; Utkin, D.O.; Khodyrev, D.S.; Kushlinskii, N.E.; Dmitriev, A.A.; et al. Novel miRNA genes deregulated by aberrant methylation in ovarian carcinoma are involved in metastasis. Gene 2018, 662, 28-36. [CrossRef] [PubMed]

117. Zhang, H.; Wang, Q.; Zhao, Q.; Di, W. MiR-124 inhibits the migration and invasion of ovarian cancer cells by targeting SphK1. J. Ovarian Res. 2013, 6, 84. [CrossRef]

118. Xiaohong, Z.; Lichun, F.; Na, X.; Kejian, Z.; Xiaolan, X.; Shaosheng, W. MiR-203 promotes the growth and migration of ovarian cancer cells by enhancing glycolytic pathway. Tumour Biol. J. Int. Soc. Oncodev. Biol. Med. 2016, 37, 14989-14997. [CrossRef]

119. Zhao, G.; Guo, Y.; Chen, Z.; Wang, Y.; Yang, C.; Dudas, A.; Du, Z.; Liu, W.; Zou, Y.; Szabo, E.; et al. miR-203 Functions as a Tumor Suppressor by Inhibiting Epithelial to Mesenchymal Transition in Ovarian Cancer. J. Cancer Sci. Ther. 2015, 7, 34-43. [CrossRef]

120. Iorio, M.V.; Visone, R.; Di Leva, G.; Donati, V.; Petrocca, F.; Casalini, P.; Taccioli, C.; Volinia, S.; Liu, C.G.; Alder, H.; et al. MicroRNA signatures in human ovarian cancer. Cancer Res. 2007, 67, 8699-8707. [CrossRef]

121. Zhang, X.; Guo, G.; Wang, G.; Zhao, J.; Wang, B.; Yu, X.; Ding, Y. Profile of differentially expressed miRNAs in high-grade serous carcinoma and clear cell ovarian carcinoma, and the expression of miR-510 in ovarian carcinoma. Mol. Med. Rep. 2015, 12, 8021-8031. [CrossRef]

122. Ye, G.; Bernaudo, S.; Peng, C. Etiology and overview. In Advances in Ovarian Cancer Management; Future Medicine Ltd.: London, UK, 2012. [CrossRef]

123. Braicu, O.L.; Budisan, L.; Buiga, R.; Jurj, A.; Achimas-Cadariu, P.; Pop, L.A.; Braicu, C.; Irimie, A.; Berindan-Neagoe, I. miRNA expression profiling in formalin-fixed paraffin-embedded endometriosis and ovarian cancer samples. Onco Targets Ther. 2017, 10, 4225-4238. [CrossRef] [PubMed]

124. Feng, W.; Dean, D.C.; Hornicek, F.J.; Shi, H.; Duan, Z. Exosomes promote pre-metastatic niche formation in ovarian cancer. Mol. Cancer 2019, 18, 124. [CrossRef]

125. Yang, L.; Wei, Q.M.; Zhang, X.W.; Sheng, Q.; Yan, X.T. MiR-376a promotion of proliferation and metastases in ovarian cancer: Potential role as a biomarker. Life Sci. 2017, 173, 62-67. [CrossRef] [PubMed] 
126. Zuberi, M.; Mir, R.; Das, J.; Ahmad, I.; Javid, J.; Yadav, P.; Masroor, M.; Ahmad, S.; Ray, P.C.; Saxena, A. Expression of serum miR-200a, miR-200b, and miR-200c as candidate biomarkers in epithelial ovarian cancer and their association with clinicopathological features. Clin. Transl. Oncol. 2015, 17, 779-787. [CrossRef] [PubMed]

127. Langhe, R.; Norris, L.; Saadeh, F.A.; Blackshields, G.; Varley, R.; Harrison, A.; Gleeson, N.; Spillane, C.; Martin, C.; O'Donnell, D.M.; et al. A novel serum microRNA panel to discriminate benign from malignant ovarian disease. Cancer Lett. 2015, 356, 628-636. [CrossRef] [PubMed]

128. Zuberi, M.; Khan, I.; Gandhi, G.; Ray, P.C.; Saxena, A. The conglomeration of diagnostic, prognostic and therapeutic potential of serum miR-199a and its association with clinicopathological features in epithelial ovarian cancer. Tumour Biol. J. Int. Soc. Oncodev. Biol. Med. 2016, 37, 11259-11266. [CrossRef]

129. Li, Y.; Liu, C.; Liao, Y.; Wang, W.; Hu, B.; Lu, X.; Cui, J. Characterizing the landscape of peritoneal exosomal microRNAs in patients with ovarian cancer by high-throughput sequencing. Oncol. Lett. 2019, 17, 539-547. [CrossRef]

130. Zhang, J.; Liu, W.; Shen, F.; Ma, X.; Liu, X.; Tian, F.; Zeng, W.; Xi, X.; Lin, Y. The activation of microRNA-520h-associated TGF-beta1/c-Myb/Smad7 axis promotes epithelial ovarian cancer progression. Cell Death Dis. 2018, 9, 884. [CrossRef]

131. Lin, J.; Zhang, L.; Huang, H.; Huang, Y.; Huang, L.; Wang, J.; Huang, S.; He, L.; Zhou, Y.; Jia, W.; et al. MiR-26b/KPNA2 axis inhibits epithelial ovarian carcinoma proliferation and metastasis through downregulating OCT4. Oncotarget 2015, 6, 23793-23806. [CrossRef]

132. Lu, J.; Zhang, W.; Ding, Y.; Li, X.; Song, J. Expression of miR-26b in ovarian carcinoma tissues and its correlation with clinicopathology. Oncol. Lett. 2019, 17, 4417-4422. [CrossRef]

133. Vang, S.; Wu, H.T.; Fischer, A.; Miller, D.H.; MacLaughlan, S.; Douglass, E.; Comisar, L.; Steinhoff, M.; Collins, C.; Smith, P.J.; et al. Identification of ovarian cancer metastatic miRNAs. PLoS ONE 2013, 8, e58226. [CrossRef] [PubMed]

134. Wahab, N.A.; Othman, Z.; Nasri, N.W.M.; Mokhtar, M.H.; Ibrahim, S.F.; Hamid, A.A.; Raja Ali, R.A.; Mokhtar, N.M. Inhibition of miR-141 and miR-200a Increase DLC-1 and ZEB2 Expression, Enhance Migration and Invasion in Metastatic Serous Ovarian Cancer. Int. J. Environ. Res. Public Health 2020, 17, 2766. [CrossRef] [PubMed]

135. McMillen, B.D.; Aponte, M.M.; Liu, Z.; Helenowski, I.B.; Scholtens, D.M.; Buttin, B.M.; Wei, J.J. Expression analysis of MIR182 and its associated target genes in advanced ovarian carcinoma. Mod. Pathol. 2012, 25, 1644-1653. [CrossRef] [PubMed]

136. Liu, Z.; Liu, J.; Segura, M.F.; Shao, C.; Lee, P.; Gong, Y.; Hernando, E.; Wei, J.J. MiR-182 overexpression in tumourigenesis of high-grade serous ovarian carcinoma. J. Pathol. 2012, 228, 204-215. [CrossRef]

137. Srivastava, A.K.; Banerjee, A.; Cui, T.; Han, C.; Cai, S.; Liu, L.; Wu, D.; Cui, R.; Li, Z.; Zhang, X.; et al. Inhibition of miR-328-3p Impairs Cancer Stem Cell Function and Prevents Metastasis in Ovarian Cancer. Cancer Res. 2019, 79, 2314-2326. [CrossRef] [PubMed]

138. Wang, Y.; Zhang, X.; Tang, W.; Lin, Z.; Xu, L.; Dong, R.; Li, Y.; Li, J.; Zhang, Z.; Li, X.; et al. miR-130a upregulates $\mathrm{mTOR}$ pathway by targeting TSC1 and is transactivated by NF-kappaB in high-grade serous ovarian carcinoma. Cell Death Differ. 2017, 24, 2089-2100. [CrossRef]

139. Liu, F.; Zhang, G.; Lv, S.; Wen, X.; Liu, P. miRNA-301b-3p accelerates migration and invasion of high-grade ovarian serous tumor via targeting CPEB3/EGFR axis. J. Cell Biochem. 2019, 120, 12618-12627. [CrossRef]

140. Lou, Y.; Yang, X.; Wang, F.; Cui, Z.; Huang, Y. MicroRNA-21 promotes the cell proliferation, invasion and migration abilities in ovarian epithelial carcinomas through inhibiting the expression of PTEN protein. Int. J. Mol. Med. 2010, 26, 819-827. [CrossRef]

141. Su, N.; Qiu, H.; Chen, Y.; Yang, T.; Yan, Q.; Wan, X. miR-205 promotes tumor proliferation and invasion through targeting ESRRG in endometrial carcinoma. Oncol. Rep. 2013, 29, 2297-2302. [CrossRef]

142. Wei, Z.; Liu, Y.; Wang, Y.; Zhang, Y.; Luo, Q.; Man, X.; Wei, F.; Yu, X. Downregulation of Foxo3 and TRIM31 by miR-551b in side population promotes cell proliferation, invasion, and drug resistance of ovarian cancer. Med. Oncol. (Northwood Lond. Engl.) 2016, 33, 126. [CrossRef]

143. Chaluvally-Raghavan, P.; Jeong, K.J.; Pradeep, S.; Silva, A.M.; Yu, S.; Liu, W.; Moss, T.; Rodriguez-Aguayo, C.; Zhang, D.; Ram, P.; et al. Direct Upregulation of STAT3 by MicroRNA-551b-3p Deregulates Growth and Metastasis of Ovarian Cancer. Cell Rep. 2016, 15, 1493-1504. [CrossRef] [PubMed] 
144. Han, X.; Zhang, Y.; Wang, D.; Fu, X.; Li, M.; Wang, A. Upregulation of microRNA-18b induces phosphatase and tensin homolog to accelerate the migration and invasion abilities of ovarian cancer. Oncol. Lett. 2017, 14, 5631-5637. [CrossRef] [PubMed]

145. Liu, D.T.; Yao, H.R.; Li, Y.Y.; Song, Y.Y.; Su, M.Y. MicroRNA-19b promotes the migration and invasion of ovarian cancer cells by inhibiting the PTEN/AKT signaling pathway. Oncol. Lett. 2018, 16, 559-565. [CrossRef] [PubMed]

146. Zhuang, R.J.; Bai, X.X.; Liu, W. MicroRNA-23a depletion promotes apoptosis of ovarian cancer stem cell and inhibits cell migration by targeting DLG2. Cancer Biol. Ther. 2019, 20, 897-911. [CrossRef]

147. Xia, Y.; Gao, Y. MicroRNA-181b promotes ovarian cancer cell growth and invasion by targeting LATS2. Biochem. Biophys. Res. Commun. 2014, 447, 446-451. [CrossRef]

148. Wang, A.; Jin, C.; Li, H.; Qin, Q.; Li, L. LncRNA ADAMTS9-AS2 regulates ovarian cancer progression by targeting miR-182-5p/FOXF2 signaling pathway. Int. J. Biol. Macromol. 2018, 120, 1705-1713. [CrossRef]

149. Liang, T.; Li, L.; Cheng, Y.; Ren, C.; Zhang, G. MicroRNA-194 promotes the growth, migration, and invasion of ovarian carcinoma cells by targeting protein tyrosine phosphatase nonreceptor type 12. Onco Targets Ther. 2016, 9, 4307-4315. [CrossRef]

150. Fan, Y.; Fan, J.; Huang, L.; Ye, M.; Huang, Z.; Wang, Y.; Li, Q.; Huang, J. Increased expression of microRNA-196a predicts poor prognosis in human ovarian carcinoma. Int. J. Clin. Exp. Pathol. 2015, 8, 4132-4137.

151. Wei, J.; Zhang, L.; Li, J.; Zhu, S.; Tai, M.; Mason, C.W.; Chapman, J.A.; Reynolds, E.A.; Weiner, C.P.; Zhou, H.H. MicroRNA-205 promotes cell invasion by repressing TCF21 in human ovarian cancer. J. Ovarian Res. 2017, 10, 33. [CrossRef]

152. Chu, P.; Liang, A.; Jiang, A.; Zong, L. miR-205 regulates the proliferation and invasion of ovarian cancer cells via suppressing PTEN/SMAD4 expression. Oncol. Lett. 2018, 15, 7571-7578. [CrossRef]

153. Li, J.; Hu, K.; Gong, G.; Zhu, D.; Wang, Y.; Liu, H.; Wu, X. Upregulation of MiR-205 transcriptionally suppresses SMAD4 and PTEN and contributes to human ovarian cancer progression. Sci. Rep. 2017, 7, 41330. [CrossRef] [PubMed]

154. Liu, H.; Pan, Y.; Han, X.; Liu, J.; Li, R. MicroRNA-216a promotes the metastasis and epithelial-mesenchymal transition of ovarian cancer by suppressing the PTEN/AKT pathway. Onco Targets Ther. 2017, 10, 2701-2709. [CrossRef] [PubMed]

155. Zhao, W.; Han, T.; Li, B.; Ma, Q.; Yang, P.; Li, H. miR-552 promotes ovarian cancer progression by regulating PTEN pathway. J. Ovarian Res. 2019, 12, 121. [CrossRef] [PubMed]

156. Rupaimoole, R.; Ivan, C.; Yang, D.; Gharpure, K.M.; Wu, S.Y.; Pecot, C.V.; Previs, R.A.; Nagaraja, A.S.; Armaiz-Pena, G.N.; McGuire, M.; et al. Hypoxia-upregulated microRNA-630 targets Dicer, leading to increased tumor progression. Oncogene 2016, 35, 4312-4320. [CrossRef] [PubMed]

157. Ying, X.; Li-ya, Q.; Feng, Z.; Yin, W.; Ji-hong, L. MiR-939 promotes the proliferation of human ovarian cancer cells by repressing APC2 expression. Biomed. Pharmacother. 2015, 71, 64-69. [CrossRef]

158. Tang, M.; Jiang, L.; Lin, Y.; Wu, X.; Wang, K.; He, Q.; Wang, X.; Li, W. Platelet microparticle-mediated transfer of miR-939 to epithelial ovarian cancer cells promotes epithelial to mesenchymal transition. Oncotarget 2017, 8, 97464-97475. [CrossRef]

159. Salem, M.; Shan, Y.; Bernaudo, S.; Peng, C. miR-590-3p Targets Cyclin G2 and FOXO3 to Promote Ovarian Cancer Cell Proliferation, Invasion, and Spheroid Formation. Int. J. Mol. Sci. 2019, 20, 1810. [CrossRef]

160. Zhou, J.; Gong, G.; Tan, H.; Dai, F.; Zhu, X.; Chen, Y.; Wang, J.; Liu, Y.; Chen, P.; Wu, X.; et al. Urinary microRNA-30a-5p is a potential biomarker for ovarian serous adenocarcinoma. Oncol. Rep. 2015, 33, 2915-2923. [CrossRef]

161. Dong, R.; Liu, X.; Zhang, Q.; Jiang, Z.; Li, Y.; Wei, Y.; Li, Y.; Yang, Q.; Liu, J.; Wei, J.J.; et al. miR-145 inhibits tumor growth and metastasis by targeting metadherin in high-grade serous ovarian carcinoma. Oncotarget 2014, 5, 10816-10829. [CrossRef]

162. Lam, S.S.; Ip, C.K.; Mak, A.S.; Wong, A.S. A novel p70 S6 kinase-microRNA biogenesis axis mediates multicellular spheroid formation in ovarian cancer progression. Oncotarget 2016, 7, 38064-38077. [CrossRef]

163. Kim, T.H.; Song, J.Y.; Park, H.; Jeong, J.Y.; Kwon, A.Y.; Heo, J.H.; Kang, H.; Kim, G.; An, H.J. miR-145, targeting high-mobility group A2, is a powerful predictor of patient outcome in ovarian carcinoma. Cancer Lett. 2015, 356, 937-945. [CrossRef] [PubMed] 
164. Pan, Y.; Robertson, G.; Pedersen, L.; Lim, E.; Hernandez-Herrera, A.; Rowat, A.C.; Patil, S.L.; Chan, C.K.; Wen, Y.; Zhang, X.; et al. miR-509-3p is clinically significant and strongly attenuates cellular migration and multi-cellular spheroids in ovarian cancer. Oncotarget 2016, 7, 25930-25948. [CrossRef] [PubMed]

165. Wang, Y.; Yan, S.; Liu, X.; Zhang, W.; Li, Y.; Dong, R.; Zhang, Q.; Yang, Q.; Yuan, C.; Shen, K.; et al. miR-1236-3p represses the cell migration and invasion abilities by targeting ZEB1 in high-grade serous ovarian carcinoma. Oncol. Rep. 2014, 31, 1905-1910. [CrossRef] [PubMed]

166. Zhang, P.; Zhu, J.; Zheng, Y.; Zhang, H.; Sun, H.; Gao, S. miRNA-574-3p inhibits metastasis and chemoresistance of epithelial ovarian cancer (EOC) by negatively regulating epidermal growth factor receptor (EGFR). Am. J. Transl. Res. 2019, 11, 4151-4165. [PubMed]

167. Liang, H.; Zhao, X.; Wang, C.; Sun, J.; Chen, Y.; Wang, G.; Fang, L.; Yang, R.; Yu, M.; Gu, Y.; et al. Systematic analyses reveal long non-coding RNA (PTAF)-mediated promotion of EMT and invasion-metastasis in serous ovarian cancer. Mol. Cancer 2018, 17, 96. [CrossRef]

168. Liang, H.; Yu, T.; Han, Y.; Jiang, H.; Wang, C.; You, T.; Zhao, X.; Shan, H.; Yang, R.; Yang, L.; et al. LncRNA PTAR promotes EMT and invasion-metastasis in serous ovarian cancer by competitively binding miR-101-3p to regulate ZEB1 expression. Mol. Cancer 2018, 17, 119. [CrossRef]

169. Liang, H.; Yu, M.; Yang, R.; Zhang, L.; Zhang, L.; Zhu, D.; Luo, H.; Hong, Y.; Yu, T.; Sun, J.; et al. A PTAL-miR-101-FN1 Axis Promotes EMT and Invasion-Metastasis in Serous Ovarian Cancer. Mol. Ther. Oncolytics 2020, 16, 53-62. [CrossRef]

170. Gong, C.; Yang, Z.; Wu, F.; Han, L.; Liu, Y.; Gong, W. miR-17 inhibits ovarian cancer cell peritoneal metastasis by targeting ITGA5 and ITGB1. Oncol. Rep. 2016, 36, 2177-2183. [CrossRef]

171. Chen, S.; Chen, X.; Xiu, Y.L.; Sun, K.X.; Zhao, Y. Inhibition of Ovarian Epithelial Carcinoma Tumorigenesis and Progression by microRNA 106b Mediated through the RhoC Pathway. PLoS ONE 2015, 10, e0125714. [CrossRef]

172. Yan, J.; Jiang, J.Y.; Meng, X.N.; Xiu, Y.L.; Zong, Z.H. MiR-23b targets cyclin G1 and suppresses ovarian cancer tumorigenesis and progression. J. Exp. Clin. Cancer Res. CR 2016, 35, 31. [CrossRef]

173. Xu, H.; Mao, H.L.; Zhao, X.R.; Li, Y.; Liu, P.S. MiR-29c-3p, a target miRNA of LINC01296, accelerates tumor malignancy: Therapeutic potential of a LINC01296/miR-29c-3p axis in ovarian cancer. J. Ovarian Res. 2020, 13, 31. [CrossRef] [PubMed]

174. Zhang, R.R.; Wang, L.M.; Shen, J.J. Overexpression of miR-32 inhibits the proliferation and metastasis of ovarian cancer cells by targeting BTLA. Eur. Rev. Med. Pharmacol. Sci. 2020, 24, 4671-4678. [CrossRef] [PubMed]

175. Dong, P.; Xiong, Y.; Watari, H.; Hanley, S.J.; Konno, Y.; Ihira, K.; Yamada, T.; Kudo, M.; Yue, J.; Sakuragi, N. MiR-137 and miR-34a directly target Snail and inhibit EMT, invasion and sphere-forming ability of ovarian cancer cells. J. Exp. Clin. Cancer Res. CR 2016, 35, 132. [CrossRef] [PubMed]

176. Peng, D.X.; Luo, M.; Qiu, L.W.; He, Y.L.; Wang, X.F. Prognostic implications of microRNA-100 and its functional roles in human epithelial ovarian cancer. Oncol. Rep. 2012, 27, 1238-1244. [CrossRef] [PubMed]

177. Yuan, L.; Li, S.; Zhou, Q.; Wang, D.; Zou, D.; Shu, J.; Huang, Y. MiR-124 inhibits invasion and induces apoptosis of ovarian cancer cells by targeting programmed cell death 6. Oncol. Lett. 2017, 14, 7311-7317. [CrossRef]

178. Cao, Y.; Shi, H.; Ren, F.; Jia, Y.; Zhang, R. Long non-coding RNA CCAT1 promotes metastasis and poor prognosis in epithelial ovarian cancer. Exp. Cell Res. 2017, 359, 185-194. [CrossRef]

179. Luo, J.; Zhou, J.; Cheng, Q.; Zhou, C.; Ding, Z. Role of microRNA-133a in epithelial ovarian cancer pathogenesis and progression. Oncol. Lett. 2014, 7, 1043-1048. [CrossRef]

180. Zhang, Y.; Dun, Y.; Zhou, S.; Huang, X.H. LncRNA HOXD-AS1 promotes epithelial ovarian cancer cells proliferation and invasion by targeting miR-133a-3p and activating Wnt/beta-catenin signaling pathway. Biomed. Pharmacother. 2017, 96, 1216-1221. [CrossRef]

181. Yang, L.; Hou, J.; Cui, X.H.; Suo, L.N.; Lv, Y.W. MiR-133b regulates the expression of CTGF in epithelial-mesenchymal transition of ovarian cancer. Eur. Rev. Med. Pharmacol. Sci. 2017, 21, 5602-5609. [CrossRef]

182. Tang, W.; Jiang, Y.; Mu, X.; Xu, L.; Cheng, W.; Wang, X. MiR-135a functions as a tumor suppressor in epithelial ovarian cancer and regulates HOXA10 expression. Cell Signal. 2014, 26, 1420-1426. [CrossRef] 
183. Duan, S.; Dong, X.; Hai, J.; Jiang, J.; Wang, W.; Yang, J.; Zhang, W.; Chen, C. MicroRNA-135a-3p is downregulated and serves as a tumour suppressor in ovarian cancer by targeting CCR2. Biomed. Pharmacother. 2018, 107, 712-720. [CrossRef]

184. Yeh, Y.M.; Chuang, C.M.; Chao, K.C.; Wang, L.H. MicroRNA-138 suppresses ovarian cancer cell invasion and metastasis by targeting SOX4 and HIF-1alpha. Int. J. Cancer 2013, 133, 867-878. [CrossRef] [PubMed]

185. Qu, M.; Zhu, Y.; Jin, M. MicroRNA-138 inhibits SOX12 expression and the proliferation, invasion and migration of ovarian cancer cells. Exp. Ther. Med. 2018, 16, 1629-1638. [CrossRef] [PubMed]

186. Liu, J.; Jin, S.; Wang, R. MicroRNA139 suppressed tumor cell proliferation, migration and invasion by directly targeting HDGF in epithelial ovarian cancer. Mol. Med. Rep. 2017, 16, 3379-3386. [CrossRef] [PubMed]

187. Xue, F.; Li, Q.R.; Xu, Y.H.; Zhou, H.B. MicroRNA-139-3p Inhibits the Growth and Metastasis of Ovarian Cancer by Inhibiting ELAVL1. Onco Targets Ther. 2019, 12, 8935-8945. [CrossRef] [PubMed]

188. Wang, Y.; Li, J.; Xu, C.; Zhang, X. MicroRNA-139-5p Inhibits Cell Proliferation and Invasion by Targeting RHO-Associated Coiled-Coil-Containing Protein Kinase 2 in Ovarian Cancer. Oncol. Res. 2018, 26, 411-420. [CrossRef] [PubMed]

189. Liu, X.; Li, Y.; Wen, J.; Qi, T.; Wang, Y. Long non-coding RNA TTN-AS1 promotes tumorigenesis of ovarian cancer through modulating the miR-139-5p/ROCK2 axis. Biomed. Pharmacother. 2020, 125, 109882. [CrossRef]

190. Zhou, J.; Zhang, X.; Li, W.; Chen, Y. MicroRNA-145-5p regulates the proliferation of epithelial ovarian cancer cells via targeting SMAD4. J. Ovarian Res. 2020, 13, 54. [CrossRef]

191. Li, L.W.; Xiao, H.Q.; Ma, R.; Yang, M.; Li, W.; Lou, G. miR-152 is involved in the proliferation and metastasis of ovarian cancer through repression of ERBB3. Int. J. Mol. Med. 2018, 41, 1529-1535. [CrossRef]

192. Jin, M.; Yang, Z.; Ye, W.; Xu, H.; Hua, X. MicroRNA-150 predicts a favorable prognosis in patients with epithelial ovarian cancer, and inhibits cell invasion and metastasis by suppressing transcriptional repressor ZEB1. PLoS ONE 2014, 9, e103965. [CrossRef]

193. Zhu, X.; Shen, H.; Yin, X.; Long, L.; Xie, C.; Liu, Y.; Hui, L.; Lin, X.; Fang, Y.; Cao, Y.; et al. miR-186 regulation of Twist1 and ovarian cancer sensitivity to cisplatin. Oncogene 2016, 35, 323-332. [CrossRef] [PubMed]

194. Mitra, A.K.; Chiang, C.Y.; Tiwari, P.; Tomar, S.; Watters, K.M.; Peter, M.E.; Lengyel, E. Microenvironment-induced downregulation of miR-193b drives ovarian cancer metastasis. Oncogene 2015, 34, 5923-5932. [CrossRef] [PubMed]

195. Li, H.; Xu, Y.; Qiu, W.; Zhao, D.; Zhang, Y. Tissue miR-193b as a Novel Biomarker for Patients with Ovarian Cancer. Med. Sci. Monit. 2015, 21, 3929-3934. [CrossRef] [PubMed]

196. Yu, H.Y.; Pan, S.S. MiR-202-5p suppressed cell proliferation, migration and invasion in ovarian cancer via regulating HOXB2. Eur. Rev. Med. Pharmacol. Sci. 2020, 24, 2256-2263. [CrossRef] [PubMed]

197. Dai, C.; Xie, Y.; Zhuang, X.; Yuan, Z. MiR-206 inhibits epithelial ovarian cancer cells growth and invasion via blocking c-Met/AKT/mTOR signaling pathway. Biomed. Pharmacother. 2018, 104, 763-770. [CrossRef] [PubMed]

198. Chang, L.; Guo, R.; Yuan, Z.; Shi, H.; Zhang, D. LncRNA HOTAIR Regulates CCND1 and CCND2 Expression by Sponging miR-206 in Ovarian Cancer. Cell. Physiol. Biochem. Int. J. Exp. Cell. Physiol. Biochem. Pharmacol. 2018, 49, 1289-1303. [CrossRef]

199. Lin, Y.; Jin, Y.; Xu, T.; Zhou, S.; Cui, M. MicroRNA-215 targets NOB1 and inhibits growth and invasion of epithelial ovarian cancer. Am. J. Transl. Res. 2017, 9, 466-477.

200. Li, J.; Li, D.; Zhang, W. Tumor suppressor role of miR-217 in human epithelial ovarian cancer by targeting IGF1R. Oncol. Rep. 2016, 35, 1671-1679. [CrossRef]

201. Li, N.; Wang, L.; Tan, G.; Guo, Z.; Liu, L.; Yang, M.; He, J. MicroRNA-218 inhibits proliferation and invasion in ovarian cancer by targeting Runx2. Oncotarget 2017, 8, 91530-91541. [CrossRef]

202. Wei, C.; Zhang, X.; He, S.; Liu, B.; Han, H.; Sun, X. MicroRNA-219-5p inhibits the proliferation, migration, and invasion of epithelial ovarian cancer cells by targeting the Twist/Wnt/beta-catenin signaling pathway. Gene 2017, 637, 25-32. [CrossRef]

203. Xing, F.; Song, Z.; He, Y. MiR-219-5p inhibits growth and metastasis of ovarian cancer cells by targeting HMGA2. Biol. Res. 2018, 51, 50. [CrossRef] [PubMed]

204. Cao, J.; Cai, J.; Huang, D.; Han, Q.; Chen, Y.; Yang, Q.; Yang, C.; Kuang, Y.; Li, D.; Wang, Z. miR-335 represents an independent prognostic marker in epithelial ovarian cancer. Am. J. Clin. Pathol. 2014, 141, 437-442. [CrossRef] [PubMed] 
205. Zhang, R.; Shi, H.; Ren, F.; Liu, Z.; Ji, P.; Zhang, W.; Wang, W. Down-regulation of miR-338-3p and Up-regulation of MACC1 Indicated Poor Prognosis of Epithelial Ovarian Cancer Patients. J. Cancer 2019, 10, 1385-1392. [CrossRef] [PubMed]

206. Wen, C.; Liu, X.; Ma, H.; Zhang, W.; Li, H. miR3383p suppresses tumor growth of ovarian epithelial carcinoma by targeting Runx2. Int. J. Oncol. 2015, 46, 2277-2285. [CrossRef]

207. Huang, Z.; Li, Q.; Luo, K.; Zhang, Q.; Geng, J.; Zhou, X.; Xu, Y.; Qian, M.; Zhang, J.A.; Ji, L.; et al. miR-340-FHL2 axis inhibits cell growth and metastasis in ovarian cancer. Cell Death Dis. 2019, 10, 372. [CrossRef]

208. Li, P.; Sun, Y.; Liu, Q. MicroRNA-340 Induces Apoptosis and Inhibits Metastasis of Ovarian Cancer Cells by Inactivation of NF-x03BA;B1. Cell. Physiol. Biochem. Int. J. Exp. Cell. Physiol. Biochem. Pharmacol. 2016, 38, 1915-1927. [CrossRef]

209. Lin, Y.; Xu, T.; Zhou, S.; Cui, M. MicroRNA-363 inhibits ovarian cancer progression by inhibiting NOB1. Oncotarget 2017, 8, 101649-101658. [CrossRef]

210. Wang, Y.; Xu, C.; Wang, Y.; Zhang, X. MicroRNA-365 inhibits ovarian cancer progression by targeting Wnt5a. Am. J. Cancer Res. 2017, 7, 1096-1106.

211. Zhang, Y.; Zhao, F.J.; Chen, L.L.; Wang, L.Q.; Nephew, K.P.; Wu, Y.L.; Zhang, S. MiR-373 targeting of the Rab22a oncogene suppresses tumor invasion and metastasis in ovarian cancer. Oncotarget 2014, 5, 12291-12303. [CrossRef]

212. Zhang, Z.; Cheng, J.; Wu, Y.; Qiu, J.; Sun, Y.; Tong, X. LncRNA HOTAIR controls the expression of Rab22a by sponging miR-373 in ovarian cancer. Mol. Med. Rep. 2016, 14, 2465-2472. [CrossRef]

213. Yu, R.; Cai, L.; Chi, Y.; Ding, X.; Wu, X. miR377 targets CUL4A and regulates metastatic capability in ovarian cancer. Int. J. Mol. Med. 2018, 41, 3147-3156. [CrossRef] [PubMed]

214. Yang, A.; Wang, X.; Yu, C.; Jin, Z.; Wei, L.; Cao, J.; Wang, Q.; Zhang, M.; Zhang, L.; Zhang, L.; et al. microRNA-494 is a potential prognostic marker and inhibits cellular proliferation, migration and invasion by targeting SIRT1 in epithelial ovarian cancer. Oncol. Lett. 2017, 14, 3177-3184. [CrossRef] [PubMed]

215. Liu, W.; Yang, Y.J.; An, Q. LINC00963 Promotes Ovarian Cancer Proliferation, Migration and EMT via the miR-378g/CHI3L1 Axis. Cancer Manag. Res. 2020, 12, 463-473. [CrossRef] [PubMed]

216. Ye, W.; Ni, Z.; Yicheng, S.; Pan, H.; Huang, Y.; Xiong, Y.; Liu, T. Anisomycin inhibits angiogenesis in ovarian cancer by attenuating the molecular sponge effect of the lncRNAMeg3/miR421/PDGFRA axis. Int. J. Oncol. 2019, 55, 1296-1312. [CrossRef] [PubMed]

217. Muys, B.R.; Sousa, J.F.; Placa, J.R.; de Araujo, L.F.; Sarshad, A.A.; Anastasakis, D.G.; Wang, X.; Li, X.L.; de Molfetta, G.A.; Ramao, A.; et al. miR-450a Acts as a Tumor Suppressor in Ovarian Cancer by Regulating Energy Metabolism. Cancer Res. 2019, 79, 3294-3305. [CrossRef] [PubMed]

218. Xu, L.; Li, H.; Su, L.; Lu, Q.; Liu, Z. MicroRNA455 inhibits cell proliferation and invasion of epithelial ovarian cancer by directly targeting Notch1. Mol. Med. Rep. 2017, 16, 9777-9785. [CrossRef] [PubMed]

219. Jiang, H.W.; Li, L.; Jiang, P.; Wang, Y.F. MicroRNA-489 targets XIAP to inhibit the biological progression of ovarian cancer via regulating PI3K/Akt signaling pathway and epithelial-to-mesenchymal transition. Eur. Rev. Med. Pharmacol. Sci. 2020, 24, 4113-4122. [CrossRef]

220. Wang, W.; Ren, F.; Wu, Q.; Jiang, D.; Li, H.; Peng, Z.; Wang, J.; Shi, H. MicroRNA-497 inhibition of ovarian cancer cell migration and invasion through targeting of SMAD specific E3 ubiquitin protein ligase 1. Biochem. Biophys. Res. Commun. 2014, 449, 432-437. [CrossRef]

221. Park, G.B.; Kim, D. MicroRNA-503-5p Inhibits the CD97-Mediated JAK2/STAT3 Pathway in Metastatic or Paclitaxel-Resistant Ovarian Cancer Cells. Neoplasia 2019, 21, 206-215. [CrossRef]

222. Yang, D.; Sun, Y.; Hu, L.; Zheng, H.; Ji, P.; Pecot, C.V.; Zhao, Y.; Reynolds, S.; Cheng, H.; Rupaimoole, R.; et al. Integrated analyses identify a master microRNA regulatory network for the mesenchymal subtype in serous ovarian cancer. Cancer Cell 2013, 23, 186-199. [CrossRef]

223. Wei, H.; Tang, Q.L.; Zhang, K.; Sun, J.J.; Ding, R.F. miR-532-5p is a prognostic marker and suppresses cells proliferation and invasion by targeting TWIST1 in epithelial ovarian cancer. Eur. Rev. Med. Pharmacol. Sci. 2018, 22, 5842-5850. [CrossRef] [PubMed]

224. Sun, X.; Cui, M.; Zhang, A.; Tong, L.; Wang, K.; Li, K.; Wang, X.; Sun, Z.; Zhang, H. MiR-548c impairs migration and invasion of endometrial and ovarian cancer cells via downregulation of Twist. J. Exp. Clin. Cancer Res. CR 2016, 35, 10. [CrossRef] [PubMed] 
225. Yang, L.; Ma, H.L. MiRNA-584 suppresses the progression of ovarian cancer by negatively regulating LPIN1. Eur. Rev. Med. Pharmacol. Sci. 2020, 24, 1062-1071. [CrossRef] [PubMed]

226. Wang, J.; Ding, W.; Xu, Y.; Tao, E.; Mo, M.; Xu, W.; Cai, X.; Chen, X.; Yuan, J.; Wu, X. Long non-coding RNA RHPN1-AS1 promotes tumorigenesis and metastasis of ovarian cancer by acting as a ceRNA against miR-596 and upregulating LETM1. Aging (Albany NY) 2020, 12, 4558-4572. [CrossRef]

227. Yu, H.; Xu, Y.; Zhang, D.; Liu, G. Long noncoding RNA LUCAT1 promotes malignancy of ovarian cancer through regulation of miR-612/HOXA13 pathway. Biochem. Biophys. Res. Commun. 2018, 503, 2095-2100. [CrossRef]

228. Duan, M.; Fang, M.; Wang, C.; Wang, H.; Li, M. LncRNA EMX2OS Induces Proliferation, Invasion and Sphere Formation of Ovarian Cancer Cells via Regulating the miR-654-3p/AKT3/PD-L1 Axis. Cancer Manag. Res. 2020, 12, 2141-2154. [CrossRef]

229. Liu, J.; Jiang, Y.; Wan, Y.; Zhou, S.; Thapa, S.; Cheng, W. MicroRNA665 suppresses the growth and migration of ovarian cancer cells by targeting HOXA10. Mol. Med. Rep. 2018, 18, 2661-2668. [CrossRef]

230. Xia, B.; Lin, M.; Dong, W.; Chen, H.; Li, B.; Zhang, X.; Hou, Y.; Lou, G. Upregulation of miR-874-3p and miR-874-5p inhibits epithelial ovarian cancer malignancy via SIK2. J. Biochem. Mol. Toxicol. 2018, 32, e22168. [CrossRef]

231. Li, C.; Yu, S.; Wu, S.; Ni, Y.; Pan, Z. MicroRNA-936 targets FGF2 to inhibit epithelial ovarian cancer aggressiveness by deactivating the PI3K/Akt pathway. Onco Targets Ther. 2019, 12, 5311-5322. [CrossRef]

232. Dasari, S.; Pandhiri, T.; Grassi, T.; Visscher, D.W.; Multinu, F.; Agarwal, K.; Mariani, A.; Shridhar, V.; Mitra, A.K. Signals from the Metastatic Niche Regulate Early and Advanced Ovarian Cancer Metastasis through miR-4454 Downregulation. Mol. Cancer Res. MCR 2020, 18, 1202-1217. [CrossRef]

233. Liu, L.; Ning, Y.; Yi, J.; Yuan, J.; Fang, W.; Lin, Z.; Zeng, Z. miR-6089/MYH9/beta-catenin/c-Jun negative feedback loop inhibits ovarian cancer carcinogenesis and progression. Biomed. Pharmacother. 2020, 125, 109865. [CrossRef]

234. Kanlikilicer, P.; Rashed, M.H.; Bayraktar, R.; Mitra, R.; Ivan, C.; Aslan, B.; Zhang, X.; Filant, J.; Silva, A.M.; Rodriguez-Aguayo, C.; et al. Ubiquitous Release of Exosomal Tumor Suppressor miR-6126 from Ovarian Cancer Cells. Cancer Res. 2016, 76, 7194-7207. [CrossRef] [PubMed]

235. Yang, J.; Li, G.; Zhang, K. MiR-125a regulates ovarian cancer proliferation and invasion by repressing GALNT14 expression. Biomed. Pharmacother. 2016, 80, 381-387. [CrossRef] [PubMed]

236. Cowden Dahl, K.D.; Dahl, R.; Kruichak, J.N.; Hudson, L.G. The epidermal growth factor receptor responsive miR-125a represses mesenchymal morphology in ovarian cancer cells. Neoplasia 2009, 11, 1208-1215. [CrossRef]

237. Yang, L.; Zhang, X.; Ma, Y.; Zhao, X.; Li, B.; Wang, H. Ascites promotes cell migration through the repression of miR-125b in ovarian cancer. Oncotarget 2017, 8, 51008-51015. [CrossRef] [PubMed]

238. Zuberi, M.; Khan, I.; Mir, R.; Gandhi, G.; Ray, P.C.; Saxena, A. Utility of Serum miR-125b as a Diagnostic and Prognostic Indicator and Its Alliance with a Panel of Tumor Suppressor Genes in Epithelial Ovarian Cancer. PLoS ONE 2016, 11, e0153902. [CrossRef] [PubMed]

239. Wei, L.Q.; Liang, H.T.; Qin, D.C.; Jin, H.F.; Zhao, Y.; She, M.C. MiR-212 exerts suppressive effect on SKOV3 ovarian cancer cells through targeting HBEGF. Tumour Biol. J. Int. Soc. Oncodev. Biol. Med. 2014, 35, 12427-12434. [CrossRef] [PubMed]

240. Duan, Y.; Dong, Y.; Dang, R.; Hu, Z.; Yang, Y.; Hu, Y.; Cheng, J. MiR-122 inhibits epithelial mesenchymal transition by regulating P4HA1 in ovarian cancer cells. Cell Biol. Int. 2018, 42, 1564-1574. [CrossRef] [PubMed]

241. Gong, L.; Wang, C.; Gao, Y.; Wang, J. Decreased expression of microRNA-148a predicts poor prognosis in ovarian cancer and associates with tumor growth and metastasis. Biomed. Pharmacother. 2016, 83, 58-63. [CrossRef]

242. Zhou, B.; Xu, H.; Xia, M.; Sun, C.; Li, N.; Guo, E.; Guo, L.; Shan, W.; Lu, H.; Wu, Y.; et al. Overexpressed miR-9 promotes tumor metastasis via targeting E-cadherin in serous ovarian cancer. Front. Med. 2017, 11, 214-222. [CrossRef]

243. Laios, A.; O'Toole, S.; Flavin, R.; Martin, C.; Kelly, L.; Ring, M.; Finn, S.P.; Barrett, C.; Loda, M.; Gleeson, N.; et al. Potential role of miR-9 and miR-223 in recurrent ovarian cancer. Mol. Cancer 2008, 7, 35. [CrossRef] [PubMed] 
244. Tang, H.; Yao, L.; Tao, X.; Yu, Y.; Chen, M.; Zhang, R.; Xu, C. miR-9 functions as a tumor suppressor in ovarian serous carcinoma by targeting TLN1. Int. J. Mol. Med. 2013, 32, 381-388. [CrossRef] [PubMed]

245. Mak, C.S.; Yung, M.M.; Hui, L.M.; Leung, L.L.; Liang, R.; Chen, K.; Liu, S.S.; Qin, Y.; Leung, T.H.; Lee, K.F.; et al. MicroRNA-141 enhances anoikis resistance in metastatic progression of ovarian cancer through targeting KLF12/Sp1/survivin axis. Mol. Cancer 2017, 16, 11. [CrossRef] [PubMed]

246. Mateescu, B.; Batista, L.; Cardon, M.; Gruosso, T.; de Feraudy, Y.; Mariani, O.; Nicolas, A.; Meyniel, J.P.; Cottu, P.; Sastre-Garau, X.; et al. miR-141 and miR-200a act on ovarian tumorigenesis by controlling oxidative stress response. Nat. Med. 2011, 17, 1627-1635. [CrossRef] [PubMed]

247. Ye, Q.; Lei, L.; Shao, L.; Shi, J.; Jia, J.; Tong, X. MicroRNA141 inhibits epithelialmesenchymal transition, and ovarian cancer cell migration and invasion. Mol. Med. Rep. 2017, 16, 6743-6749. [CrossRef]

248. Suo, H.B.; Zhang, K.C.; Zhao, J. MiR-200a promotes cell invasion and migration of ovarian carcinoma by targeting PTEN. Eur. Rev. Med. Pharmacol. Sci. 2018, 22, 4080-4089. [CrossRef]

249. Pecot, C.V.; Rupaimoole, R.; Yang, D.; Akbani, R.; Ivan, C.; Lu, C.; Wu, S.; Han, H.D.; Shah, M.Y.; Rodriguez-Aguayo, C.; et al. Tumour angiogenesis regulation by the miR-200 family. Nat. Commun. 2013, 4, 2427. [CrossRef]

250. Sun, Q.; Zou, X.; Zhang, T.; Shen, J.; Yin, Y.; Xiang, J. The role of miR-200a in vasculogenic mimicry and its clinical significance in ovarian cancer. Gynecol. Oncol. 2014, 132, 730-738. [CrossRef]

251. Nam, E.J.; Yoon, H.; Kim, S.W.; Kim, H.; Kim, Y.T.; Kim, J.H.; Kim, J.W.; Kim, S. MicroRNA expression profiles in serous ovarian carcinoma. Clin. Cancer Res. Off. J. Am. Assoc. Cancer Res. 2008, 14, 2690-2695. [CrossRef]

252. Lu, Y.M.; Shang, C.; Ou, Y.L.; Yin, D.; Li, Y.N.; Li, X.; Wang, N.; Zhang, S.L. miR-200c modulates ovarian cancer cell metastasis potential by targeting zinc finger E-box-binding homeobox 2 (ZEB2) expression. Med. Oncol. (Northwood Lond. Engl.) 2014, 31, 134. [CrossRef]

253. Cochrane, D.R.; Spoelstra, N.S.; Howe, E.N.; Nordeen, S.K.; Richer, J.K. MicroRNA-200c mitigates invasiveness and restores sensitivity to microtubule-targeting chemotherapeutic agents. Mol. Cancer Ther. 2009, 8, 1055-1066. [CrossRef] [PubMed]

254. Wang, B.; Li, X.; Zhao, G.; Yan, H.; Dong, P.; Watari, H.; Sims, M.; Li, W.; Pfeffer, L.M.; Guo, Y.; et al. miR-203 inhibits ovarian tumor metastasis by targeting BIRC5 and attenuating the TGFbeta pathway. J. Exp. Clin. Cancer Res. CR 2018, 37, 235. [CrossRef] [PubMed]

255. Zhang, L.; Huang, J.; Yang, N.; Greshock, J.; Megraw, M.S.; Giannakakis, A.; Liang, S.; Naylor, T.L.; Barchetti, A.; Ward, M.R.; et al. microRNAs exhibit high frequency genomic alterations in human cancer. Proc. Natl. Acad. Sci. USA 2006, 103, 9136-9141. [CrossRef] [PubMed]

256. Hirata, Y.; Murai, N.; Yanaihara, N.; Saito, M.; Saito, M.; Urashima, M.; Murakami, Y.; Matsufuji, S.; Okamoto, A. MicroRNA-21 is a candidate driver gene for 17q23-25 amplification in ovarian clear cell carcinoma. BMC Cancer 2014, 14, 799. [CrossRef]

257. Filippova, E.A.; Loginov, V.I.; Burdennyi, A.M.; Braga, E.A.; Pronina, I.V.; Kazubskaya, T.P.; Kushlinskii, D.N.; Utkin, D.O.; Fridman, M.V.; Khodyrev, D.S.; et al. Hypermethylated Genes of MicroRNA in Ovarian Carcinoma: Metastasis Prediction Marker Systems. Bull. Exp. Biol. Med. 2019, 167, 79-83. [CrossRef] [PubMed]

258. Braga, E.A.; Loginov, V.I.; Filippova, E.A.; Burdennyi, A.M.; Pronina, I.V.; Kazubskaya, T.P.; Khodyrev, D.S.; Utkin, D.O.; Kushlinskii, D.N.; Adamyan, L.V.; et al. Diagnostic Value of a Group of MicroRNA Genes Hypermethylated in Ovarian Carcinoma. Bull. Exp. Biol. Med. 2018, 166, 253-256. [CrossRef]

259. Hermeking, H. MicroRNAs in the 553 network: Micromanagement of tumour suppression. Nat. Rev. Cancer 2012, 12, 613-626. [CrossRef]

260. Welponer, H.; Tsibulak, I.; Wieser, V.; Degasper, C.; Shivalingaiah, G.; Wenzel, S.; Sprung, S.; Marth, C.; Hackl, H.; Fiegl, H.; et al. The miR-34 family and its clinical significance in ovarian cancer. J. Cancer 2020, 11, 1446-1456. [CrossRef]

261. Tian, M.; Tian, D.; Qiao, X.; Li, J.; Zhang, L. Modulation of Myb-induced NF-kB -STAT3 signaling and resulting cisplatin resistance in ovarian cancer by dietary factors. J. Cell. Physiol. 2019, 234, 21126-21134. [CrossRef]

262. Luo, S.; Wang, J.; Ma, Y.; Yao, Z.; Pan, H. PPARgamma inhibits ovarian cancer cells proliferation through upregulation of miR-125b. Biochem. Biophys. Res. Commun. 2015, 462, 85-90. [CrossRef] 
263. Vignati, S.; Albertini, V.; Rinaldi, A.; Kwee, I.; Riva, C.; Oldrini, R.; Capella, C.; Bertoni, F.; Carbone, G.M.; Catapano, C.V. Cellular and molecular consequences of peroxisome proliferator-activated receptor-gamma activation in ovarian cancer cells. Neoplasia 2006, 8, 851-861. [CrossRef] [PubMed]

264. Kim, S.; Lee, J.J.; Heo, D.S. PPARgamma ligands induce growth inhibition and apoptosis through p63 and p73 in human ovarian cancer cells. Biochem. Biophys. Res. Commun. 2011, 406, 389-395. [CrossRef] [PubMed]

265. Zeineldin, R.; Muller, C.Y.; Stack, M.S.; Hudson, L.G. Targeting the EGF receptor for ovarian cancer therapy. J. Oncol. 2010, 2010, 414676. [CrossRef] [PubMed]

266. Merritt, W.M.; Lin, Y.G.; Han, L.Y.; Kamat, A.A.; Spannuth, W.A.; Schmandt, R.; Urbauer, D.; Pennacchio, L.A.; Cheng, J.F.; Nick, A.M.; et al. Dicer, Drosha, and outcomes in patients with ovarian cancer. N. Engl. J. Med. 2008, 359, 2641-2650. [CrossRef] [PubMed]

267. Mori, M.; Triboulet, R.; Mohseni, M.; Schlegelmilch, K.; Shrestha, K.; Camargo, F.D.; Gregory, R.I. Hippo signaling regulates microprocessor and links cell-density-dependent miRNA biogenesis to cancer. Cell 2014, 156, 893-906. [CrossRef] [PubMed]

268. Suzuki, H.I.; Yamagata, K.; Sugimoto, K.; Iwamoto, T.; Kato, S.; Miyazono, K. Modulation of microRNA processing by p53. Nature 2009, 460, 529-533. [CrossRef] [PubMed]

269. Han, C.; Liu, Y.; Wan, G.; Choi, H.J.; Zhao, L.; Ivan, C.; He, X.; Sood, A.K.; Zhang, X.; Lu, X. The RNA-binding protein DDX1 promotes primary microRNA maturation and inhibits ovarian tumor progression. Cell Rep. 2014, 8, 1447-1460. [CrossRef] [PubMed]

270. Peng, S.; Kuang, Z.; Sheng, C.; Zhang, Y.; Xu, H.; Cheng, Q. Association of microRNA-196a-2 gene polymorphism with gastric cancer risk in a Chinese population. Dig. Dis. Sci. 2010, 55, 2288-2293. [CrossRef] [PubMed]

271. Christensen, B.C.; Avissar-Whiting, M.; Ouellet, L.G.; Butler, R.A.; Nelson, H.H.; McClean, M.D.; Marsit, C.J.; Kelsey, K.T. Mature microRNA sequence polymorphism in MIR196A2 is associated with risk and prognosis of head and neck cancer. Clin. Cancer Res. Off. 2010, 16, 3713-3720. [CrossRef] [PubMed]

272. Hoffman, A.E.; Zheng, T.; Yi, C.; Leaderer, D.; Weidhaas, J.; Slack, F.; Zhang, Y.; Paranjape, T.; Zhu, Y. microRNA miR-196a-2 and breast cancer: A genetic and epigenetic association study and functional analysis. Cancer Res. 2009, 69, 5970-5977. [CrossRef]

273. Song, Z.S.; Wu, Y.; Zhao, H.G.; Liu, C.X.; Cai, H.Y.; Guo, B.Z.; Xie, Y.A.; Shi, H.R. Association between the rs11614913 variant of miRNA-196a-2 and the risk of epithelial ovarian cancer. Oncol. Lett. 2016, 11, 194-200. [CrossRef] [PubMed]

274. Lukacs, J.; Soltesz, B.; Penyige, A.; Nagy, B.; Poka, R. Identification of miR-146a and miR-196a-2 single nucleotide polymorphisms at patients with high-grade serous ovarian cancer. J. Biotechnol. 2019, 297, 54-57. [CrossRef] [PubMed]

275. Liu, R.; Martin, T.A.; Jordan, N.J.; Ruge, F.; Ye, L.; Jiang, W.G. Metastasis suppressor 1 expression in human ovarian cancer: The impact on cellular migration and metastasis. Int. J. Oncol. 2015, 47, 1429-1439. [CrossRef] [PubMed]

276. Georgescu, M.M. PTEN Tumor Suppressor Network in PI3K-Akt Pathway Control. Genes Cancer 2010, 1, 1170-1177. [CrossRef]

277. Niu, K.; Shen, W.; Zhang, Y.; Zhao, Y.; Lu, Y. MiR-205 promotes motility of ovarian cancer cells via targeting ZEB1. Gene 2015, 574, 330-336. [CrossRef]

278. Li, J.; Li, L.; Li, Z.; Gong, G.; Chen, P.; Liu, H.; Wang, J.; Liu, Y.; Wu, X. The role of miR-205 in the VEGF-mediated promotion of human ovarian cancer cell invasion. Gynecol. Oncol. 2015, 137, 125-133. [CrossRef]

279. Ghoneum, A.; Said, N. PI3K-AKT-mTOR and NFkappaB Pathways in Ovarian Cancer: Implications for Targeted Therapeutics. Cancers 2019, 11, 949. [CrossRef]

280. Xu, G.; Bernaudo, S.; Fu, G.; Lee, D.Y.; Yang, B.B.; Peng, C. Cyclin G2 is degraded through the ubiquitin-proteasome pathway and mediates the antiproliferative effect of activin receptor-like kinase 7. Mol. Biol. Cell 2008, 19, 4968-4979. [CrossRef]

281. Bernaudo, S.; Salem, M.; Qi, X.; Zhou, W.; Zhang, C.; Yang, W.; Rosman, D.; Deng, Z.; Ye, G.; Yang, B.B.; et al. Cyclin G2 inhibits epithelial-to-mesenchymal transition by disrupting Wnt/beta-catenin signaling. Oncogene 2016, 35, 4816-4827. [CrossRef]

282. Fu, G.; Peng, C. Nodal enhances the activity of FoxO3a and its synergistic interaction with Smads to regulate cyclin G2 transcription in ovarian cancer cells. Oncogene 2011, 30, 3953-3966. [CrossRef] 
283. Zhang, Y.; Chen, Q. Relationship between matrix metalloproteinases and the occurrence and development of ovarian cancer. Braz. J. Med. Biol. Res. 2017, 50, e6104. [CrossRef] [PubMed]

284. Yang, Z.; Jin, P.; Xu, S.; Zhang, T.; Yang, X.; Li, X.; Wei, X.; Sun, C.; Chen, G.; Ma, D.; et al. Dicer reprograms stromal fibroblasts to a pro-inflammatory and tumor-promoting phenotype in ovarian cancer. Cancer Lett. 2018, 415, 20-29. [CrossRef] [PubMed]

285. Stone, R.L.; Nick, A.M.; McNeish, I.A.; Balkwill, F.; Han, H.D.; Bottsford-Miller, J.; Rupairmoole, R.; Armaiz-Pena, G.N.; Pecot, C.V.; Coward, J.; et al. Paraneoplastic thrombocytosis in ovarian cancer. N. Engl. J. Med. 2012, 366, 610-618. [CrossRef] [PubMed]

286. Liang, R.; Chen, X.; Chen, L.; Wan, F.; Chen, K.; Sun, Y.; Zhu, X. STAT3 signaling in ovarian cancer: A potential therapeutic target. J. Cancer 2020, 11, 837-848. [CrossRef] [PubMed]

287. Hill, L.; Browne, G.; Tulchinsky, E. ZEB/miR-200 feedback loop: At the crossroads of signal transduction in cancer. Int. J. Cancer 2013, 132, 745-754. [CrossRef] [PubMed]

288. Eichler, W.; Hamann, J.; Aust, G. Expression characteristics of the human CD97 antigen. Tissue Antigens 1997, 50, 429-438. [CrossRef]

289. Yona, S.; Lin, H.H.; Siu, W.O.; Gordon, S.; Stacey, M. Adhesion-GPCRs: Emerging roles for novel receptors. Trends Biochem. Sci. 2008, 33, 491-500. [CrossRef]

290. Li, J.; Zhou, B.P. Activation of beta-catenin and Akt pathways by Twist are critical for the maintenance of EMT associated cancer stem cell-like characters. BMC Cancer 2011, 11, 49. [CrossRef]

291. Pan, Y.; Tong, J.H.M.; Lung, R.W.M.; Kang, W.; Kwan, J.S.H.; Chak, W.P.; Tin, K.Y.; Chung, L.Y.; Wu, F.; $\mathrm{Ng}$, S.S.M.; et al. RASAL2 promotes tumor progression through LATS2/YAP1 axis of hippo signaling pathway in colorectal cancer. Mol. Cancer 2018, 17, 102. [CrossRef]

292. Li, S.; Yu, Z.; Chen, S.S.; Li, F.; Lei, C.Y.; Chen, X.X.; Bao, J.M.; Luo, Y.; Lin, G.Z.; Pang, S.Y.; et al. The YAP1 oncogene contributes to bladder cancer cell proliferation and migration by regulating the H19 long noncoding RNA. Urol. Oncol. 2015, 33, 427.e1-427.e10. [CrossRef]

293. Guo, C.; Wang, X.; Liang, L. LATS2-mediated YAP1 phosphorylation is involved in HCC tumorigenesis. Int. J. Clin. Exp. Pathol. 2015, 8, 1690-1697. [PubMed]

294. Lu, Q.; Longo, F.M.; Zhou, H.; Massa, S.M.; Chen, Y.H. Signaling through Rho GTPase pathway as viable drug target. Curr. Med. Chem. 2009, 16, 1355-1365. [CrossRef] [PubMed]

295. Ghosh, D.; Bagley, A.F.; Na, Y.J.; Birrer, M.J.; Bhatia, S.N.; Belcher, A.M. Deep, noninvasive imaging and surgical guidance of submillimeter tumors using targeted M13-stabilized single-walled carbon nanotubes. Proc. Natl. Acad. Sci. USA 2014, 111, 13948-13953. [CrossRef]

296. Lessan, K.; Aguiar, D.J.; Oegema, T.; Siebenson, L.; Skubitz, A.P. CD44 and beta1 integrin mediate ovarian carcinoma cell adhesion to peritoneal mesothelial cells. Am. J. Pathol. 1999, 154, 1525-1537. [CrossRef]

297. Morgan, M.R.; Byron, A.; Humphries, M.J.; Bass, M.D. Giving off mixed signals-distinct functions of alpha5beta1 and alphavbeta3 integrins in regulating cell behaviour. IUBMB Life 2009, 61, 731-738. [CrossRef] [PubMed]

298. Iwanicki, M.P.; Davidowitz, R.A.; Ng, M.R.; Besser, A.; Muranen, T.; Merritt, M.; Danuser, G.; Ince, T.A.; Brugge, J.S. Ovarian cancer spheroids use myosin-generated force to clear the mesothelium. Cancer Discov. 2011, 1, 144-157. [CrossRef]

299. Abate-Shen, C. Deregulated homeobox gene expression in cancer: Cause or consequence? Nat. Rev. Cancer 2002, 2, 777-785. [CrossRef]

300. Li, B.; Jin, H.; Yu, Y.; Gu, C.; Zhou, X.; Zhao, N.; Feng, Y. HOXA10 is overexpressed in human ovarian clear cell adenocarcinoma and correlates with poor survival. Int. J. Gynecol. Cancer 2009, 19, 1347-1352. [CrossRef]

301. Seeber, L.M.; Horree, N.; Vooijs, M.A.; Heintz, A.P.; van der Wall, E.; Verheijen, R.H.; van Diest, P.J. The role of hypoxia inducible factor-1alpha in gynecological cancer. Crit. Rev. Oncol. Hematol. 2011, 78, 173-184. [CrossRef]

302. Markert, E.K.; Levine, A.J.; Vazquez, A. Proliferation and tissue remodeling in cancer: The hallmarks revisited. Cell Death Dis. 2012, 3, e397. [CrossRef]

303. Hu, X.; Macdonald, D.M.; Huettner, P.C.; Feng, Z.; El Naqa, I.M.; Schwarz, J.K.; Mutch, D.G.; Grigsby, P.W.; Powell, S.N.; Wang, X. A miR-200 microRNA cluster as prognostic marker in advanced ovarian cancer. Gynecol. Oncol. 2009, 114, 457-464. [CrossRef] 
304. van Jaarsveld, M.T.; Helleman, J.; Boersma, A.W.; van Kuijk, P.F.; van Ijcken, W.F.; Despierre, E.; Vergote, I.; Mathijssen, R.H.; Berns, E.M.; Verweij, J.; et al. miR-141 regulates KEAP1 and modulates cisplatin sensitivity in ovarian cancer cells. Oncogene 2013, 32, 4284-4293. [CrossRef] [PubMed]

305. Chen, J.L.; Chen, F.; Zhang, T.T.; Liu, N.F. Suppression of SIK1 by miR-141 in human ovarian cancer cell lines and tissues. Int. J. Mol. Med. 2016, 37, 1601-1610. [CrossRef] [PubMed]

306. Zheng, H.; Kang, Y. Multilayer control of the EMT master regulators. Oncogene 2014, 33, 1755-1763. [CrossRef] [PubMed]

307. Dykxhoorn, D.M. MicroRNAs and metastasis: Little RNAs go a long way. Cancer Res. 2010, 70, 6401-6406. [CrossRef]

308. Olson, P.; Lu, J.; Zhang, H.; Shai, A.; Chun, M.G.; Wang, Y.; Libutti, S.K.; Nakakura, E.K.; Golub, T.R.; Hanahan, D. MicroRNA dynamics in the stages of tumorigenesis correlate with hallmark capabilities of cancer. Genes Dev. 2009, 23, 2152-2165. [CrossRef]

309. Imai, T.; Horiuchi, A.; Shiozawa, T.; Osada, R.; Kikuchi, N.; Ohira, S.; Oka, K.; Konishi, I. Elevated expression of E-cadherin and alpha-, beta-, and gamma-catenins in metastatic lesions compared with primary epithelial ovarian carcinomas. Hum. Pathol. 2004, 35, 1469-1476. [CrossRef]

310. Nowek, K.; Wiemer, E.A.C.; Jongen-Lavrencic, M. The versatile nature of miR-9/9(*) in human cancer. Oncotarget 2018, 9, 20838-20854. [CrossRef]

311. Gang, W.; Tanjun, W.; Yong, H.; Jiajun, Q.; Yi, Z.; Hao, H. Inhibition of miR-9 decreases osteosarcoma cell proliferation. Bosn. J. Basic Med. Sci. 2020, 20, 218-225. [CrossRef]

312. Hersi, H.M.; Raulf, N.; Gaken, J.; Folarin, N.; Tavassoli, M. MicroRNA-9 inhibits growth and invasion of head and neck cancer cells and is a predictive biomarker of response to plerixafor, an inhibitor of its target CXCR4. Mol. Oncol. 2018, 12, 2023-2041. [CrossRef]

313. Dochez, V.; Caillon, H.; Vaucel, E.; Dimet, J.; Winer, N.; Ducarme, G. Biomarkers and algorithms for diagnosis of ovarian cancer: CA125, HE4, RMI and ROMA, a review. J. Ovarian Res. 2019, 12, 28. [CrossRef] [PubMed]

314. Wu, S.G.; Chang, T.H.; Liu, Y.N.; Shih, J.Y. MicroRNA in Lung Cancer Metastasis. Cancers 2019, 11, 265. [CrossRef] [PubMed]

(C) 2020 by the authors. Licensee MDPI, Basel, Switzerland. This article is an open access article distributed under the terms and conditions of the Creative Commons Attribution (CC BY) license (http://creativecommons.org/licenses/by/4.0/). 